\author{
UNIVERSIDADE DE SÃO PAULO \\ FACULDADE DE FILOSOFIA, LETRAS E CIÊNCIAS HUMANAS \\ DEPARTAMENTO DE LINGÜÍSTICA \\ PROGRAMA DE PÓS-GRADUAÇÃO EM SEMIÓTICA E LINGÜÍSTICA GERAL
}

\author{
DANIEL LEVY CANDEIAS
}

\title{
LOURENÇO MUTARELLI, LITERATURA E MITOLOGIA
}

\begin{abstract}
Dissertação apresentada ao Programa de Pós-Graduação em Lingüística e Semiótica do Departamento de Lingüística da Faculdade de Filosofia, Letras e Ciências Humanas da Universidade de São Paulo para obtenção do título de mestre em Letras.
\end{abstract}

Orientador: Prof. Dr. Antônio Vicente Seraphim Pietroforte

São Paulo

2007 


\section{ÍNDICE}

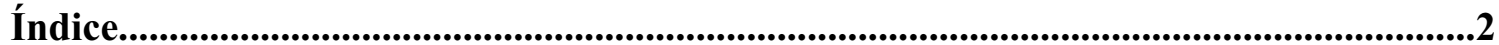

Introdução

Dedicatória.......................................................................................................................6

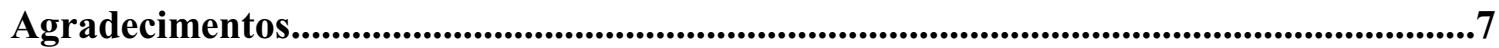

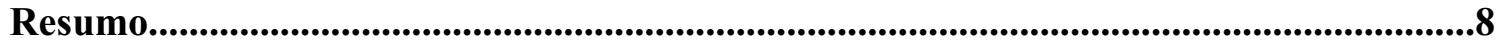

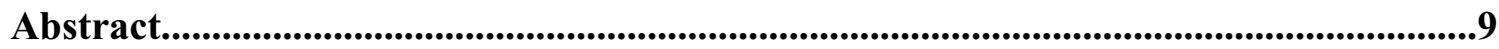

Uma poética do desequilíbrio psicológico..............................................................................10

O Cheiro do Ralo e lítotes...........................................................................................................35

Jesus Kid e ironia..................................................................................................................63

O Natimorto: relação de concordância entre enunciado e enunciação...............................85

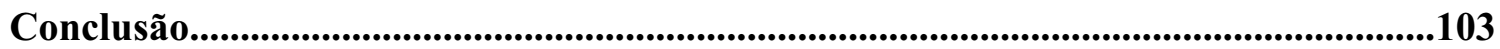

Bibliografia..............................................................................................................................106 


\section{INTRODUÇÃO}

Lourenço Mutarelli nasce em 1964, na cidade de São Paulo. Interessado em desenho, completa curso de Educação Artística na Faculdade Belas Artes. Dois anos depois, o aperfeiçoamento técnico enseja o início de uma longa carreira como redator e desenhista de quadrinhos. O primeiro desses trabalhos é Over-12, editado pelo famoso quadrinista Francisco Marcatti; no ano seguinte, vem a público Solúvel. A partir de então, são lançados, com intervalo máximo de três anos, os quadrinhos Transubstanciação, Desgraçados, Eu te amo Lucimar, A confluência da forquilha, O dobro de cinco, O rei do ponto, A soma de tudo - parte 1. Dentre eles, Transubstanciação se destaca por conter Réquiem, história supostamente autobiográfica na qual o autor revela a possível experiência traumática que o leva a desenvolver síndrome do pânico.

Em 2002, é editado $O$ Cheiro do Ralo, romance de estréia, que se torna o mais conhecido do escritor, por conta de futura adaptação para cinema. No mesmo ano, ocorre também o lançamento do quadrinho A soma de tudo - parte 2. Os romances $O$ Natimorto um musical silencioso e Jesus Kid são publicados, nessa ordem, em 2004, dando prosseguimento à carreira literária, que toma espaço dos quadrinhos: o autor declara a intenção de abandonar produções desse tipo.

Ainda em 2004, chega a público o filme do diretor Heitor Dhalia, intitulado Nina, para o qual Mutarelli elabora as animações. O roteiro é baseado no romance Crime $e$ Castigo, do escritor russo Dostoievski. Em 2005, a Companhia da Mentira encena o primeiro texto de teatro de Mutarelli, $O$ que você foi quando era criança?, a montagem leva indicação ao $18^{\circ}$ Prêmio Shell de Teatro na categoria de melhor autor.

O diretor de Nina estréia adaptação de O Cheiro do Ralo em 2006, marcando a carreira do autor, por causa da boa repercussão do longa-metragem. No mesmo ano, é lançado o livro em quadrinhos $A$ caixa de areia. Seu último trabalho publicado é $O$ Teatro das Sombras, que reúne cinco peças de sua autoria; dentre elas O Que Você foi Quando Era Criança?.

O Cheiro do Ralo trata de um perturbado dono de loja de penhores, que se apaixona por uma mulher por causa de sua bunda, e volta quase toda a atenção para o ralo fétido de seu local de trabalho, lhe atribuindo muitos significados e modos de ser. Em O Natimorto, o personagem-principal, O Agente, interessa-se por uma cantora, A Voz, cuja voz é tão 
pura que não pode ser ouvida. Com a teoria de que as advertências dos versos de embalagens de cigarro compõem um tarô, propõe à moça que se confinem ambos num quarto de hotel, onde tenta adivinhar a sorte do dia conforme a imagem encontrada nos maços comprados diariamente. Eugênio, narrador-personagem de Jesus Kid, é contratado para escrever um roteiro sobre o processo de criação. Para receber o dinheiro correspondente a esse trabalho, são também impostas as condições de que ele o termine em três meses e, que, durante o período, não saia de um hotel.

O primeiro capítulo deste trabalho pretende analisar a obra romanesca de Lourenço Mutarelli como um todo. Com base no conceito lingüístico de poética, nas definições de Roman Jakobson, características do autor são depreendidas segundo seu modo de operar a composição literária. Identificam-se recorrências figurativas, temáticas, narrativas, que acarretam determinados efeitos de sentido, que interferem na veredicção e no ethos, por exemplo. A confluência dessas características contribui para o estabelecimento de um sentido geral, ou de um aspecto dominante cujo resultado parece ser a estética do desequilíbrio psicológico.

Nos três capítulos seguintes, são feitas as análises dos três romances publicados pelo autor até o presente momento: $O$ Cheiro do Ralo, Jesus Kid e O Natimorto.

A partir dos primeiros parágrafos, $O$ Cheiro do Ralo é analisado, sobretudo, pelo efeito do lítotes, que se define pela negação no enunciado e a afirmação na enunciação. Também se estudam a paródia das formas recorrentes de composição literária e sua relação com o distúrbio psicológico, que, no nível discursivo, participam de discussões sobre literatura e seu papel diante da sociedade.

De modo análogo aos procedimentos analíticos utilizados para estudar o romance anterior, se aborda Jesus Kid por meio dos parágrafos de abertura, no quais já se depreende o gênero parodiado: o roteiro. Também se encontra um processo retórico que se estabelece na relação entre enunciação e enunciado, a ironia, que permite novamente o tema da literatura e sua função. Por causa da temática coincidente e do acionamento de processos retóricos de base semelhantes, os dois romances são analisados subseqüentemente, a despeito de se contrariar a cronologia de publicação.

Faz-se necessário, para o entendimento das obras, um breve estudo das relações que se estabelecem entre narrador e enunciador. Seu aprofundamento mais sistemático está na 
abordagem de $O$ Cheiro do Ralo, no qual não há relação dominante entre enunciação e enunciado desestabilizada por meio de processos definidos pela retórica. $\mathrm{O}$ tema da literatura não recorre, dando ensejo ao estudo do nível discursivo com base nas associações isotópicas estabelecidas pelo narrador entre campos figurativos diversos: histórias antigas, situações atuais, tarô, embalagens de cigarro e teorias de filósofos alemães do final do século XIX.

O último capítulo, resgatando o primeiro para sintetizar os outros, tem objetivo de definir uma diretriz temática, a fim de relacionar a poética e o discurso do autor a um sentido global que lhe determine semioticamente. Para tanto, se utilizam seus próprios modos de entender a literatura e a sociedade e a oposição que Lévi-Strauss estabelece entre o pensamento mágico e o científico. 
Dedico este trabalho a João Eduardo Martin, Gláucia Exposito, Eduardo Prado, Karen Gracieli, Gustavo Nóbrega e Lourenço Mutarelli. 
Agradeço pela ajuda e instrução de José Luís Fiorin, Antônio Vicente Seraphim Pietroforte e Ivã Carlos Lopes; e pelo apoio da minha família: Maria Lúcia, Mariana, Manoel e Líria. 


\section{RESUMO}

O presente trabalho consiste numa abordagem semiótica da obra literária de Lourenço Mutarelli, a qual compreende três romances: O Cheiro do Ralo, O Natimorto e Jesus Kid. Os textos são estudados com base em desenvolvimentos promovidos por semioticistas na área de semiótica poética e literatura; no que diz respeito a essa última, sobretudo as colaborações de Denis Bertrand em seu livro Caminhos da Semiótica Literária. Por conta das características do autor estudado, se propõem discussões a respeito de ethos, veredicção, enunciador e narrador; conceitos mais diretamente ligados à retórica e a Análise do Discurso.

\section{Palavras-chave}

Lourenço Mutarrelli

Literatura

Semiótica

Veredicção

Greimas

Denis Bertrand 


\section{ABSTRACT}

This work consists of a boarding semiotics of the literary composition of Lourenço Mutarelli, who wrote three romances: $O$ Cheiro do Ralo, O Natimorto and Jesus Kid. The texts are studied on the basis of developments promoted in the area of poetical semiotics and litereray semiotics. This work uses the contributions of Denis Bertrand in its book Caminhos da semiótica literária and Roman Jakobson in Lingüística e Comunicação. For account of the characteristics of the studied author if they consider quarrels regarding ethos, verediction, enunciator and narrator; concepts more directly on to the rhetoric and the analysis of the speech.

\section{Keywords}

Lourenço Mutarrelli

Literatura

Semiótica

Veredicção

Greimas

Denis Bertrand 


\section{UMA POÉTICA DO DESEQUILÍBRIO PSICOLÓGICO}

Este capítulo tem o objetivo de levantar características que possam definir ou indicar a poética dos romances de Lourenço Mutarelli. Antes de cumprir essas finalidades, é preciso que se façam algumas discussões a respeito do controverso conceito de "poética", presente na Lingüística, Semiótica e Teoria Literária.

Segundo parece, o primeiro uso do termo cujo alcance ganha definitiva importância na cultura ocidental é de Aristóteles, em sua consagrada obra A Poética (Aristóteles,1998.). Tratado dividido em duas partes, comédia e tragédia, das quais apenas a segunda resiste às vicissitudes históricas, A Poética levanta traços essenciais ao teatro; e a partir deles sugere elementos necessários à boa composição dramatúrgica. Constituem-se, desse modo, duas vertentes: uma descritiva e outra prescritiva. Ambas ainda estão presentes em grande parte dos trabalhos de crítica literária, nos quais se descrevem características de construção, e essas são prescritas ou proscritas, dependendo da posição ou filiação do crítico.

No campo da Lingüística, o termo ganha maior relevo com o ensaio "Lingüística e Poética”, de Roman Jakobson, no qual é definido o conceito de função poética:

"A função poética projeta o princípio de equivalência do eixo de seleção sobre o eixo de combinação." (Jakobson, 2003: 130)

Consagrada pela reformulação na terminologia Saussuriana, "a projeção do eixo paradigmático no eixo sintagmático" recorre nos trabalhos de Lingüística, Comunicação e Semiótica.

No que diz respeito a essa área, Ensaios de Semiótica Poética (Greimas: 1976) é um livro que marca o uso do termo em questão. Apesar de não se vincular diretamente a Jakobson, apresenta o conceito de isotopia e "recorrência" de expressão e/ou conteúdo (próximos à função definida pelo lingüista russo), vinculando-os ao poético. Outro dado importante, segundo o ponto de vista de Greimas, é a postulação de que o caráter poético não se restringe ao gênero "poesia": 
"Todavia, à primeira vista, ela parece indiferente à linguagem em que se manifesta: fala-se muito em cinema poético e em teatro poéticos e acontece-nos ter sonhos poéticos. Situando-nos no ponto de vista dos efeitos de sentido produzidos sobre o ouvinte, seria possível considerar, por extensão, como poético o que para outras civilizações depende do sagrado: hinos, rituais cantados, assim como certos textos religiosos ou filosóficos. Desta maneira, para formar uma primeira idéia do objeto da semiótica poética, poderíamos dizer:

a) que o discurso poético não é coextensivo ao conceito de literatura;

b) que, em princípio, ele é indiferente à linguagem em que é produzido;

c) que sua percepção intuitiva como discurso a um só tempo "poético e sagrado" provém dos efeitos de sentido característicos de uma classe particular de discursos." (Greimas, 1976:11-12)

O conceito de "poética" de que faz uso este trabalho recupera elementos das três definições reunidas acima. Trata-se do reconhecimento ou descrição de elementos de composição literária, dos quais se depreende a "projeção do eixo paradigmático no eixo sintagmático" ou nos quais recorrem traços, seja de expressão ou conteúdo, para que "a equivalência seja promovida à condição de recurso constitutivo da seqüência" (Jakobson, 2003).

Por conta desse uso, é legitimada a aplicação do conceito ao texto em prosa. Nesse último, recursos como modo de narração, percurso figurativo, construção de personagens, e assim por diante, podem ser considerados efeitos poéticos, já que, além da recorrência, sua elaboração é determinada por um segundo sentido, cuja razão de ser aparece somente na totalidade do texto. Acresce-se que, se for depreendida a poética de uma obra, pode-se, por meio da relação com as outras, estabelecer a poética de seu autor.

Assim, talvez seja legítimo afirmar, por exemplo, que o recurso estilístico de pontuação com parágrafos longos onde há raros pontos finais, utilizado por Raduan Nassar, faz parte de sua poética de romance. Afinal, encontra-se em Lavoura Arcaica e Um copo de cólera, mas em nenhum dos contos de Menina a caminho. O segundo sentido ou razão de ser dessa recorrência talvez se deva à estilização do discurso de um narrador apaixonado, cuja paixão torna o tempo da narrativa presente; a narração e o narrado seguem o mesmo ritmo fluido - de amor, num caso; de ira, no outro. 
Em Mutarelli, há uma série de recursos poéticos utilizados, dos quais é possível inferir o distúrbio psicológico como razão de ser. Nos três romances publicados até o presente momento, não apenas o narrador assume um discurso cujo efeito de sentido é se mostrar psicologicamente perturbado, como a perturbação serve de figura e tema.

No primeiro deles, $O$ Cheiro do Ralo (Mutarelli, 2002.), em se tratando de enredo, os elementos mais importantes ligados a distúrbios psicológicos são as fixações que o narrador-personagem tem pela bunda de uma mulher e pelo ralo entupido de sua loja de penhores. No segundo, O Natimorto (Mutarelli, 2004.), as fixações são uma cantora cuja voz não pode ser ouvida e as embalagens de cigarro; no verso das quais, sob o ponto de vista do narrador-personagem, podem ser encontradas previsões, já que, para ele, as figuras de advertência correspondem a um novo tarô. No terceiro, Jesus Kid (Mutarelli, 2004.), a principal fixação que perturba a mente é imposta: o roteiro que o escritor, narradorpersonagem, tem de elaborar para melhorar sua condição financeira.

Esses são elementos de enredo fundamentais que indicam a presença do desequilíbrio psicológico. È possível levantar outros com relação ao espaço, sempre reduzido, dando conta, porém, de inúmeros percursos temáticos e figurativos, já que a imaginação interfere na realidade na medida em que lhe é conferido uma constituição verdictória idêntica à do real. A história narrada em $O$ Cheiro do Ralo, com exceção de alguns episódios curtos ao ar livre, se passa numa habitação, na loja de penhores e num "boteco". Depois da rodoviária e da casa do narrador-personagem, que propiciam seu encontro com a cantora, a trama de $O$ Natimorto completa-se num quarto. O final de Jesus Kid ocorre justamente com a libertação do hotel no qual o escritor é obrigado a se instalar por três meses.

Considerando a ligação isotópica que se estabelece entre o espaço e o enredo, definem-se três diferentes modos de articulação que constituem figurativizações específicas do desequilíbrio psicológico.

No caso de $O$ Cheiro do Ralo, a recorrência de espaços fechados não parece uma escolha do narrador-personagem e nem um dado de relevância, na medida em que faz parte do trajeto que compõe seu cotidiano. Todavia, em se tratando de um bem-sucedido dono de loja de penhores, nada impõe a ele os limites de seu local de trabalho, casa e "boteco"; do mesmo modo como a seleção operada pelo narrador poderia se focar nos espaços abertos desse cotidiano. A escolha implícita do personagem e a seleção do narrador, ator que age e 
julga a um só tempo, servem de alicerce para uma interoceptividade extensiva, que a partir de poucos elementos externos cria, por meio da imaginação, uma série de percursos. Nos três espaços fechados que predominam no romance, ao menos um elemento do mundo natural, valorizado pela timia, assume grandes proporções, disfóricas ou eufóricas. O mais importante deles está na loja: o ralo, que dá nome ao livro. Na iminência de ele transbordar, o narrador sobrevaloriza-o passionalmente, considerando-o um actante, e uma figura positiva ou negativa, que pode estar ligada a inúmeros sentidos. No boteco, o elemento de fixação é a bunda (a parte do corpo e a mulher). Somente ela e seus efeitos de sentido exagerados (como o de "salvação", por exemplo) que o narrador depreende dão conta dos conflitos e transformações decorridos ali. Nesse caso, a ligação entre o elemento de fixação e o espaço é mais forte, já que o personagem dá a entender que o único motivo que mantém constante sua freqüência no lugar é a presença da bunda. No local onde mora, a televisão e os livros ensejam o fluxo imaginário; a suspeita da existência de algo desconhecido com traços humanos - vultos, fios de cabelo... - cumpre função semelhante à do ralo, constituindo-se como uma espécie de ator, entre o real e o imaginário, correspondente ao anti-sujeito.

Em $O$ Natimorto, é explícita a ligação entre o espaço onde ocorre a narrativa e o distúrbio psicológico, que se manifesta por meio do julgamento duvidoso sobre a lógica do mundo natural, cujo sentido é, em parte, re-configurada segundo a imaginação do narrador. Isso porque o quarto de hotel é uma escolha declarada, na condição de refúgio contra a crueldade do mudo exterior. A cantora a quem o narrador acompanha e as embalagens de cigarro passíveis de interpretação (imaginária) a respeito do destino são os elementos básicos que constituem a narrativa: a mulher ganha uma série de valores e funções; o tarô fictício indica percursos, sugere temas concernentes à realidade vivida pelo personagem, opera mudanças nos valores.

De modo análogo ao que ocorre com a fixação imposta (escritura do roteiro), o espaço fechado também é um dever em Jesus Kid. Faz parte do contrato a reclusão por três meses e a necessidade de incluir tanto essa informação como a do mesmo prazo para o término da encomenda no próprio conteúdo do roteiro. Em se tratando da divisão entre personagem e narrador, pode-se notar que ambas as funções, que, num caso escolhem e, no outro, selecionam o espaço, são manipuladas de forma a manter a isotopia do espaço 
fechado com as fixações - nesse caso, o próprio uso da imaginação como forma de recriar o mundo natural figurativa, valorativa e actancialmente, é imposto.

A perturbação ou desequilíbrio psicológico se manifesta de maneira e grau distintos em cada um dos narradores. Configuram-se tipos diferentes de ethos perturbado conforme a consciência em relação à perturbação, e esse saber possui vínculo com o poder, na medida em que quanto menos o sujeito é cognitivo, é mais passional e impotente. O quadro semiótico abaixo ilustra essas relações:

paixão/ser

razão/fazer

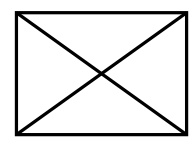

não-razão/fazer

não-paixão/ser

(As relações entre paixão e ser e razão e ser encontram-se mais detidamente desenvolvidas no capítulo sobre Jesus Kid.)

Em $O$ Cheiro do Ralo, o narrador (o mais inconsciente dos três em relação ao desequilíbrio) completa o percurso de razão/fazer a paixão/ser, nulificado com a morte. A visão do vulto, a supervalorização dos significados do ralo e da bunda, a aceitação da incoerência que certos fatos possuem entre si, as demonstrações de problemas de percepção do real (quando, por exemplo, percebe que é incapaz de reconhecer o rosto da mulher cuja bunda admira), compõem um personagem inconscientemente desequilibrado, pois é quase incapaz de distinguir a imaginação da realidade. $\mathrm{O}$ que dá a medida da insanidade são justamente essas demonstrações e algumas intervenções de outros personagens.

Os elementos citados, todavia, não aparecem, desde o início do romance até o desfecho com a mesma freqüência e grau de importância. Há um movimento progressivo que pode ser percebido por meio da relação cada vez mais intensa que o dono da loja de penhores estabelece com o ralo e a bunda. No começo da narrativa, apesar de bastante 
dominado pela paixão, ele comanda as relações de compra e venda no trabalho e submete as mulheres; ao final, perde bastante dinheiro para uma que reverte o jogo do pagamento por favores sexuais, e é assassinado justamente por uma moça antes submetida contraindo, portanto, a dupla figura de mulher e vendedor, ambos vingados.

O narrador-personagem de $O$ Natimorto está entre inconsciência e semiconsciência. O modo como a narrativa se constitui não pressupõe indistinção entre real imaginário com tanta intensidade quanto em $O$ Cheiro do Ralo. Há menos incoerências perceptivas sem que sejam nitidamente apresentadas como tal; ao contrário do romance anterior, quase não se encontram delírios visuais, olfativos ou sonoros - o que torna mais fácil diferenciar a isotopia real da imaginária. Diferentemente do que ocorre com o dono da loja de penhores, a maioria das figuras (ralo, bunda, vulto, sapo de macumba) que ensejam a ação imaginária não vem de acontecimentos que se dão durante a narrativa: vem do tarô de cigarros e de histórias pregressas não necessariamente verídicas. Ou seja, os pontos de partida para a imaginação do narrador estão mais claramente presentes nele, segundo se depreende da relação entre narrador e narrado.

A despeito de o desequilíbrio psicológico não aparecer tanto na narração, sua presença no narrado é evidente. Por meio dos diálogos, sabe-se que o produtor musical (narrador-personagem), além de se medicar e sofrer crises, possui histórico de internação. As referências diretas aos problemas psíquicos do personagem principal são mais recorrentes em $O$ Natimorto; e isso ocorre também porque os outros personagens têm mais espaço no romance. Enquanto a imaginação do dono da loja de penhores toma gradativamente o lugar do espaço exterior, interferindo na veredicção do texto a ponto de não se discernir exatamente real de imaginário; em O Natimorto, sobretudo por conta do ponto de vista da Voz, torna-se mais claro até que ponto o narrador delira. Mesmo diante de sua confiança, é evidente o caráter despropositado de suas interpretações do tarô de cigarros, o elemento que enseja o processo mais recorrente de desequilíbrio.

$\mathrm{Na}$ ordem do fazer, a diferença principal entre os dois narradores talvez concirna ao fato de que o primeiro realiza um percurso em direção à impotência total (morte), e o segundo sugere a realização de uma performance, cujo julgamento como verdadeira se efetiva apenas no âmbito da fantasia. De qualquer modo, o discernimento entre real e imaginário é suficiente para que, no desfecho do romance, o narrador se mostre certo 
quando desconfiava das más intenções do Maestro, que seduz sua mulher e, em seguida A Voz. A ambigüidade entre consciência e inconsciência se manifesta no campo das preocupações: em $O$ Cheiro do Ralo, os objetos e actantes imaginários preenchem quase completamente esse campo; em $O$ Natimorto, além do tarô, o personagem se ocupa do estado "real" das mulheres por quem sente atração. Na cena final, o assassinato da segunda que o submete representa tanto a consciência da necessidade de revira-volta quanto a inconsciência de que a solução não é sensata.

Em Jesus Kid, o narrador é explicitamente desequilibrado; isso se manifesta nas diversas vezes em que ele se medica para controlar medo ou ansiedade exagerados. Do mesmo modo como o espaço (hotel) e a fixação (roteiro) são impostos por outro sujeito, a fusão entre real e imaginário possui condição semelhante. Por meio da construção do romance, depreende-se que o contrato estabelecido entre os produtores e o escritor, incluindo sua condições, fazem parte de uma mesma isotopia, pois, segundo suas próprias exigências, o contrato faz parte da realidade e da imaginação.

É a mesma condição grande parte dos elementos que compõem o romance. Um bom exemplo para ilustrá-la é Jesus Kid. Em princípio, trata-se de um personagem criado pelo narrador Eugênio, e que, portanto, pode ser considerado um elemento integrante da isotopia do imaginário. Entretanto, em dado momento, Jesus Kid passa a interferir na isotopia real, configurando, desse modo, junção entre fantasia e realidade; o que se acentua no decorrer do romance até seu fim.

Tal característica poderia sugerir que o percurso do narrador-personagem, dirigido por uma inconsciência progressiva, termina no estado de paixão/ser, oposto ao de razão/fazer. A assunção dessa indistinção entre real e imaginário é, contudo, um modo de cumprir a tarefa de terminar o roteiro. $\mathrm{Na}$ realidade, o modo de construção do romance estabelece um percurso cujo objetivo é revelar que ele é o próprio roteiro. A interferência cada vez mais intensa do imaginário é a solução encontrada - portanto, tomada de consciência, conjunção com um saber-fazer - pelo narrador, que soluciona, inclusive, as perturbações causadas pela obrigação de escrever.

Operando-se a distinção entre as funções de narrador e personagem, pode-se afirmar que saber e fazer aparentam configurações do desequilíbrio psicológico (falsidade e impotência), mas que, no decorrer da narrativa, mostram-se fazer e saber efetivos por meio 
de um recurso metalingüístico - falsidade e impotência aparecem como meras criações, soluções estéticas que compõem o texto de um artista (narrador-personagem) cujo dado "auto-biográfico" não pode ser muito bem definido. Assim, o desequilíbrio psicológico aparece como construto; e esse caráter se torna mais claro na medida em que o narradorpersonagem torna-se mais consciente e se aproxima da finalização de sua tarefa.

Desse modo, no campo figurativo, é possível resumir as características que fundamentam a tipologia de narradores segundo as formas de aparição do distúrbio e a resposta cognitiva do narrador em relação a elas. No primeiro dos romances, encontram-se somente algumas referências a respeito de medicamentação e consultas que se supõe serem com psiquiatra. Contudo, o narrador-personagem não desenvolve nenhum pensamento mais definitivo a respeito do assunto, enquanto delira sem mostrar saber que o faz. No segundo, a limitada consciência permite ao personagem explicitar que escolhe a reclusão por conta de seu medo do mundo; sem, no entanto, desejar que seu estado patológico se transforme. No terceiro, o consumo de remédios psiquiátricos é frenético, as perturbações o incomodam; e a paranóia mais grave, escritura do roteiro encomendado, além de evidente, se resolve quando o saber-fazer é adquirido.

A oposição entre razão e paixão é recorrente em alguns trabalhos; todavia ser $\mathrm{x}$ fazer talvez não possua a mesma validade. Segundo o percurso canônico, paixões, como a ira, podem contribuir para ação, constituindo vingança, por exemplo. Contudo, nos textos de Mutarelli, a paixão mais recorrente e predominante sobre as outras é a do pânico ou medo. Seu modo de ser é o de paralisar o sujeito amedrontado. Sobredeterminando a instância cognitiva, essa paixão faz que as possibilidades de malfadar, diante de um percurso de base ou de uso, pareçam as mais prováveis, além de tornar aparentemente mais graves as conseqüências advindas do fracasso. Como se sabe, o julgamento indica, num contexto específico, o nome dado às paixões; o que, geralmente, se deve à intensidade com que ela é manifestada e o modo como a cultura classifica excessos e moderações. Ao que parece, a distinção entre pânico e medo advém justamente dessa gradação: medo é mais moderado, e pânico mais excessivo. Segundo o dicionário Caldas Aulete:

"Medo: 1. Emoção que se sente diante de um perigo ou de uma ameaça. 2. Ansiedade diante de uma situação desagradável, possibilidade de fracasso, etc." 
"Pânico: Pavor intenso e repentino, às vezes sem motivo aparente, e que provoca reações desequilibradas.”

As duas medidas, que configuram paixões diferentes, podem ser encontradas nos três romances, mas como, em geral, há excesso frente às possibilidades, a mais presente é a do pânico. A forma como ela é discursivisada não é sempre a mesma. Caso se retomem os tipos de consciência, depreende-se, em maior predominância, no romance de grau menos consciente, o pânico mostrado, mas pouco dito; o que corresponde ao desequilíbrio presente na função de narrador a ponto de ele manifestar a perturbação mais do que narrar. No texto descrito como ambíguo, O Natimorto, o pânico é dito e mostrado; contudo, sem haver superação. No de maior consciência, o caráter manifesto e declarado dessa paixão revelam o percurso de conjunção com um saber que leva à realização da performance, por meio da qual o ser dá lugar ao fazer; a paixão dá lugar à razão.

Os recursos lingüísticos que constituem esses "mostrar" e "dizer" da paixão do pânico estão ligados ao modo de referir, que pode ser direto ou indireto; declarado ou não declarado. Ambos estão presentes nos três romances; entretanto, com predominância diferente, como está apontado acima. Os seguintes trechos servem de exemplo para os dois casos:

“A Voz-Desculpe a transparência do meu baby-doll.

O Agente - As transparências enganam.

Eu sou assexuado, eu sou assexuado... repito mentalmente." (Mutarelli, 2002: 43)

"Jogo mais dois betabloqueadores para dentro. Adiciono a eles dois dos amarelos e um dos brancos. Passei muito tempo na banheira, tenho medo de ter pego uma gripe. Ou uma pneumonia, ou pior, uma pneumonia asiática." (Mutarelli, 2004: 32)

No primeiro trecho, o medo não é declarado, mas sim sugerido por conta da ação dos personagens. O esforço do produtor em não se atrair pela Voz pode ser depreendido do discurso direto em que, mentalmente, se repete a afirmação de que é "assexuado". Trata-se do medo da atração, que, aparentemente, não é tão importante; mas, que, considerando o 
enredo, mostra-se excessivo e relevante. Afinal, além de drástica, a solução da assexualidade é cogitada para resolver um problema geral com o sexo oposto (talvez com todos os seres humanos), causado pela traição da esposa.

No segundo, o medo é declarado por conta do uso da própria palavra. A narração do consumo de remédios, feita logo anteriormente, relaciona-o com um descontrole em relação a essa paixão. Em seguida, o receio de conseqüências cada vez mais drásticas e desmedidas em relação à causa revelam a passagem do medo ao pânico. Assim, declarado por meio da palavra medo e relacionado com seus percursos que o tornam excessivo, o pânico se apresenta de modo mais direto do que no trecho anterior.

É necessário ressaltar que o distúrbio psicológico vinculado ao pânico faz parte, em alguma medida, do ethos do próprio enunciador Lourenço Mutarelli. Isso porque, além de suas produções artísticas anteriores (quadrinhos) possuírem características que o afirmam, há um texto, que faz parte de Transubstanciação, em que ele (enunciador) declara ter desenvolvido síndrome do pânico, após ter sido seqüestrado, numa brincadeira de amigos.

A utilização do pânico como paixão recorrente em seus narradores pode ser considerada recurso auto-referencial, pois se refere ao enunciador. Também corresponde A um aspecto metalingüístico, justamente por tornar clara a presença de um enunciador produtor de ficções, já que os romances não se apresentam como autobiográficos. Mutarelli utiliza tal procedimento mais de uma vez; exemplos são os personagens que aparecem no Cheiro do Ralo e em Jesus Kid cujos nomes são Lourenço - mais adiante, a razão de ser desse recurso é analisada.

Há outro dado em comum em relação ao pânico dos quadrinhos e da prosa. $\mathrm{Na}$ narração dos primeiros, uma origem traumática enseja o desequilíbrio psicológico; e o mesmo ocorre nos romances. O abandono pelo pai traumatiza o dono da loja de penhores; e parece acompanhar seus delírios. Prova disso é a constante repetição de Rosebud (palavra retirada do longa-metragem "Cidadão Kane", de Orson Welles) e as referências ao "Conto de natal", de Mário de Andrade, já que, em ambos, há problemas traumáticos de relacionamento entre pai e filho.

Os fatos que marcam a vida do produtor artístico e acarretam distúrbios psíquicos também estão ligados à infância. Um deles é o sofrimento de um ataque de um cão. Outro, o episódio em que sua tia que cumpriu o papel de mãe não consegue mais reconhecê-lo por 
conta de um derrame. Passada a infância, é a traição da esposa. Não há muitas referências quanto a outros tipos de trauma, porém, a perturbação do escritor e roteirista de Jesus Kid, de modo coerente à constituição do texto, origina-se, sobretudo, do compromisso de escrever.

Assim, no que diz respeito aos narradores, pode-se depreender um percurso narrativo que faz parte da construção de uma imagem: a origem traumática, de disjunção disfórica é necessária para que se estabeleça o ethos do desequilibrado psicológico, em cujo desequilíbrio, a paixão do pânico recorre. Entretanto, oriundo de um percurso narrativo em que o sujeito é colocado em disjunção disfórica com o objeto de valor, esse medo se torna, freqüentemente, ira, podendo acionar o fazer que restitui a perda - vingança. Nos romances que seguem $O$ Cheiro do Ralo, ocorre transição entre medo/pânico e ira; em alguns casos, a palavra "vingança" é discursivisada para nomear a reação ao estado disfórico.

\section{Em O Natimorto:}

“O Agente - Não é só da minha mulher que estou falando.

O Agente - Eu falo de tudo e de todos.

O Agente - Eu não suporto mais ser agredido.

O Agente - Então eu te proponho isso.

A Voz-Isso o quê?

O Agente - Bom, com as economias que eu tenho acho que poderiamos viver nesse quarto de hotel por, aproximadamente, uns cinco ou seis anos.

A Voz-Meu Deus!

O Agente - E veja bem, isso sem nunca precisarmos sair daqui.

O Agente - E ainda existe a chance de que por fim nos esqueçam aqui, ai viveríamos aqui pelo resto de nossas vidas... Protegidos..." (Mutarelli, 38: 2004)

“Agora me alimento novamente de rancor, e estou sedento por sua volta. Ela não era nada antes que eu descobrisse o seu valor. Mas o Maestro, o velho Maestro a roubou de mim. Mas se eu a descobri, a quem ela pertence? E eu espero que ela resista a todos os incontáveis golpes que merece. Estou fraco agora mas sei que antes de começar, basta ganhar o primeiro para ganhar força. Então, ela vem, a força. Uma força desmedida plena de revigorante prazer. E depois dela será o Maestro. E depois o seu filho. E depois minha ex. E assim seguirei. E esse do vitiligo também, e quem mais cruzar meu caminho" (Mutarelli, 137-138: 2004) 
Em Jesus Kid:

"Vou transformar minha fúria que se transmudou em medo em história de acalentar Gargantas." (Mutarelli, 2004:108)

Enquanto nos primeiros trechos, a transição entre medo e ira não é discursivisada num mesmo momento; ocorre o inverso no último. Trata-se de manifestações de diferentes narradores; como está dito, o primeiro entre inconsciência e semiconsciência, portanto, ambivalente; e o segundo, em direção à consciência. Se se considerar a consciência como figurativização de um saber, de cuja aquisição depende a realização da performance (fazer), torna-se coerente a sugestão da vingança em O Natimorto, e sua explicitação em Jesus Kid, incluindo a declaração da passagem de uma paixão à outra por meio da palavra "transmudou".

O medo e a ira aparecem difusamente em $O$ Cheiro do Ralo, por causa da inconsciência do narrador-personagem. Na realidade, o modo de ser de sua perturbação ou o grau de delírio de seu discurso tornam impossível definir uma paixão predominante. Depreende-se uma forma apaixonada de enunciação por meio da qual a interioridade do enunciador ganha a dimensão de totalidade do mundo natural; os valores e os actantes fazem parte da interioridade do enunciador, que a preenche com figuras em alguma medida associáveis.

Excetuando o caso anterior, há, portanto, dois modos de reação ao percurso disjuntivo disfórico, que determinam modalizações específicas. Um deles é o estado do medo, modalizado por um não-poder-fazer, passível de culminar no pânico generalizado, uma espécie de contrato fiduciário disfórico, em que a espera é de disjunção com o objeto de valor. O outro é o da ira, que, ao contrário do esquema exposto anteriormente, associa paixão e fazer, quando o sujeito efetiva a vingança - uma das sugestões do final ambivalente de $O$ Natimorto e a solução efetiva de Jesus Kid.

Levando em conta as observações anteriores, entende-se que, a rigor, o quadrado semiótico de categoria semântica paixão/ser x razão/fazer corresponde a situações que envolvem a paixão do pânico ou ao tipo de desequilíbrio psicológico presente em $O$ Cheiro 
do Ralo. Note-se que as relações passionais, em casos como o presente, não respondem de modo regular às transformações narrativas. $\mathrm{O}$ que define as reações emotivas do sujeito do ser não são apenas os estados juntivos; mas também a relação entre eles e a forma afetiva que lhes são atribuídas. Muitas vezes, o modo de ser de um sujeito passional não se limita ao irascível ou melancólico; há sujeitos divididos e volúveis; de modo que não só os valores e relações juntivas transformam os estados de alma, mas esses podem também modificar as valorações repentinamente. Esse parece ser o caso de $O$ Cheiro do Ralo, que é analisado no segundo capítulo do presente trabalho.

Outro ponto que confirma a poética do desequilíbrio psicológico é o modo como é constituída a veredicção, que se estabelece por meio da relação entre icônico e abstrato. Em Caminhos da Semiótica literária (2003), Denis Bertrand discute o efeito de sentido referencial a partir desses conceitos:

“A diferença semântica precisa entre os pólos icônico e abstrato é interpretada pela semântica
estrutural em termos de densidade sêmica. Queremos dizer com isso a densidade não somente
dos traços que entram na construção do formante figurativo, mas também a das redes
associativas que ela possibilita com outros formantes. A iconicidade ocorrerá se os traços que o
formante reúne forem suficientes para permitir sua interpretação como representante de um
objeto do mundo natural [...] Nos textos, a iconização poderá ser formada se a densidade
sêmica dos traços for elevada, ou, em outras palavras, se o semema escolhido admitir muito
poucas variações semêmicas e suas associações forem bastante restritivas [...] É o caso, por
exemplo, dos termos técnicos e especializados nos romances naturalistas, que produzem,
independentemente do conhecimento que o leitor venha a ter de sua significação efetiva, um
efeito de referenciação forte: o semema designa uma coisa e uma só, num contexto
sociocultural preciso (o 'gradador', em Germinal, por exemplo)”. (Bertrand, 2002: 210211.)

Levando o excerto em consideração, é possível afirmar que a isotopia figurativa dos romances de Lourenço Mutarelli tende ao icônico referencial, sendo "desconectada" diversas vezes nos eixos paradigmático e sintagmático. Em ambos, há elipse ou fragmentação. No eixo paradigmático, recorrem associações e tematizações (transformações do icônico em abstrato) muitas vezes parciais e incoerentes. No eixo 
sintagmático, encontram-se contradições e "desiconizações", segundo a terminologia proposta por Bertrand, definindo a escrita de Michaux:

\footnotetext{
"A singularidade da escrita de Michaux assenta essencialmente, não sobre a denegação de um universo figurativo referencializável, como fizeram os poetas surrealistas (as figuras do mundo, afinal, estão ali, dispostas no discurso), mas sobre a introdução de uma dúvida fundamental quanto a sua confiabilidade”. (Bertrand, 2002:246)
}

No que tange a tempo, espaço e personagens, alicerces da forma romanesca, a referencialidade irregular é bastante perceptível. No que diz respeito ao tempo, deduz-se que todas as narrações se dão num período próximo à atualidade; por conta de referências contemporâneas como autores, filmes e às razoavelmente recentes advertências do verso dos cigarros. Entretanto, não se declaram dia, mês e ano definidos; apenas os dias semanais: segunda-feira, terça-feira, etc. - o que. Nesse sentido, pode ser considerado como um tempo fragmentário ou elíptico.

O tempo decorrido na ação do romance também é, de alguma forma, aproximado, mas não é preciso. Em $O$ Cheiro do Ralo, por conta da divisão semanal, imagina-se que a história decorra num período de algumas semanas. Entretanto, não é possível ter certeza, pois a extensão do texto, que é quase correspondente ao tempo decorrido no início do romance, perde tal regularidade no transcorrer da narrativa. A correspondência inicial se dá por meio da divisão entre capítulos e dias, sendo que os primeiros têm aproximadamente o mesmo tamanho (a duração e importância dos acontecimentos também interferem na extensão). Contudo, as reflexões do narrador ganham mais espaço, e a divisão em dias começa a não mais ser efetivada.

Em O Natimorto, há referência a dias, principalmente, seu fins e começos (quando o Agente dorme e acorda), mas não são explicitados a quais dias da semana eles correspondem. Da rapidez dos episódios e do encontro com o Maestro, que tem prazo determinado, é possível depreender apenas que a narração se passa no período de algumas semanas. Por causa da menor extensão do livro e da menor quantidade de acontecimentos, o tempo parece mais curto do que o de $O$ Cheiro do Ralo, porém, nada garante que essa impressão esteja correta - efeito da desiconização do tempo, operada pelo modo fragmentário de narrar. 
Da mesma forma, não se declara em que mês, dia ou ano ocorre a ação de Jesus Kid; sabe-se apenas que há um prazo de três meses para que o roteiro seja terminado. Como o final do livro é justamente esse término, trata-se do período mais definido dos romances de Mutarelli - prova disso é a explicitação do tempo transcorrido entre o encontro que define as condições do contrato com os produtores e o começo das tarefas: uma semana (Mutarelli, 2004: 22). Entretanto, como há poucos elementos que indiquem a relação mais exata entre os episódios (como o registro freqüente do tempo restante para terminar o prazo), ainda é possível entender o tempo como fragmentário; na medida em que se apresentam alguns dados em relação aos períodos e ao momento em que se passa a ação, sem que eles constituam um referencial definitivo.

O espaço é construído de modo análogo. Os ambientes são urbanos e predominantemente fechados. Todavia, em oposição, ao dado "sociocultural preciso" do Naturalismo, em nenhum trecho se expõem nomes de países, cidades, bairros ou ruas (excetuando "centro"). Supõe-se que as narrativas ocorrem no Brasil, apenas por causa de referências que não diferem muito das indicações de contemporaneidade. Determinar a cidade ou estado é tarefa quase impossível, já que a seleção feita pelo narrador inclui poucos locais, que, em geral, estão presentes em lugares de elevado a médio grau de urbanização: moradia, hotel, boteco, loja de conveniência, restaurante, loja de penhores.

Por meio da categoria espacial aberto $\mathrm{x}$ fechado, apesar de a tendência à última ser constante na obra como um todo, é possível estabelecer uma linha gradativa entre os três romances, na qual se encontra do espaço aberto ao mais fechado: O Cheiro do Ralo, Jesus Kid e $O$ Natimorto.

Pode-se afirmar que $\mathrm{O}$ Cheiro do Ralo é o romance em que o espaço é menos fechado, por haver, nele, três locais onde a ação predomina: boteco, loja de penhores e a moradia do narrador-personagem. Aparecem também outras figuras espaciais, como uma loja de conveniência, um café, um consultório e a rua, que pode ser considerada espaço aberto. É importante ressaltar, pensando novamente nos graus de consciência, que a escolha do narrador-personagem por ambientes fechados não é declarada - manifestando características de um narrador inconsciente, pois sua reclusão transforma o mundo reduzido; atribuindo valores e funções actanciais a elementos do mundo natural que não costumam atingir as dimensões que lhes são imputadas; como o ralo, por exemplo. 
Em Jesus Kid e O Natimorto, o espaço praticamente se reduz ao hotel, com as diferenças de que, no primeiro, o espaço externo aparece no fim, como libertação, e apesar da saída proibida, há mobilidade do narrador-personagem no saguão, auditório, corredor, restaurante e elevador. No segundo, o espaço externo compõe o início do romance, indicando um percurso que vai do mais aberto ao mais fechado; e a ação narrada no hotel não transpõe os limites do quarto. É necessário relembrar que, no que diz respeito a escolha e consciência, o narrador ambíguo (produtor musical) escolhe o espaço fechado, e o mais consciente (roteirista) é obrigado a aceitá-lo.

Conforme consciência com relação ao desequilíbrio psicológico, escolha de espaço, fixação, espaço, constitui-se a seguinte tabela:

\begin{tabular}{|l|l|l|l|l|l|}
\hline romance & $\begin{array}{l}\text { narrador- } \\
\text { personagem }\end{array}$ & consciência & $\begin{array}{l}\text { escolha de } \\
\text { espaço }\end{array}$ & $\begin{array}{l}\text { fixação } \\
\text { principal }\end{array}$ & espaço \\
\hline $\begin{array}{l}\text { O Cheiro do } \\
\text { Ralo }\end{array}$ & $\begin{array}{l}\text { dono da loja } \\
\text { de penhores }\end{array}$ & inconsciente & não declarada & ralo & - fechado \\
\hline Natimorto & produtor & ambíguo & $\begin{array}{l}\text { espaço } \\
\text { escolhido }\end{array}$ & $\begin{array}{l}\text { tarô de } \\
\text { cigarros }\end{array}$ & + fechado \\
\hline Jesus Kid & escritor & consciente & $\begin{array}{l}\text { espaço } \\
\text { imposto }\end{array}$ & roteiro & $+/$ fechado \\
\hline
\end{tabular}

No que concerne aos personagens, funções como profissões, características particulares ou semelhanças, se encontram em lugar dos nomes. A fragmentação é uma das bases para esse recurso; a outra está no campo associativo, pois o que substitui os nomes se origina do acionamento de uma figura de linguagem. No caso das características particulares e profissões, antonomásia ou metonímia; no caso das semelhanças, metáfora. Essa nomeação se dá de modo implícito ou explícito, caso seja usada a letra maiúscula no início da palavra ou não.

A "Voz", o "Agente", a "Esposa" e o "Maestro", personagens principais de $O$ Natimorto são exemplos evidentes de antonomásia. Em $O$ Cheiro do ralo, onde essas figuras são menos explícitas (conforme a explicação acima), há a ex-namorada do dono da loja de penhores, "ex"; o narrador-personagem, de quem se comenta a semelhança com o 
ator do comercial de Bombril; e a "bunda"; cujos nomes são mencionados pelos personagens e omitidos pelo narrador:

\author{
"Seu nome era a mistura de pelo menos outros três. \\ Seu pai, sua mãe e algum astro de TV. \\ Ela pergunta o meu. Eu falo." (Mutarelli, 2002: 14)
}

Em Jesus Kid, a nomeação é quase mania do narrador. A grande maioria dos nomes próprios constitui associações. Jesus Kid é união de Jesus Cristo e Billy the Kid (mito cristão e herói de faroeste). Eugênio (narrador-personagem) sugere a junção do pronome “eu” com o qualificativo "gênio". Máximo, um dos produtores, faz jus à pretensão que lhe é atribuída. Lourenço, um homem de idade avançada, sem movimentos, é o primeiro nome de Mutarelli. Arlindo, recepcionista do hotel, é formado por "ar" e "lindo".

Alguns desses personagens recebem nomes novos: os produtores tornam-se Gargantas Profundas (referência ao filme pornô "Garganta Profunda"), porque falam demais; o recepcionista de hotel é renomeado Chet, nome do recepcionista de Barton Fink, filme citado muitas vezes no romance. Cadela em Pink, professora de ginástica que aparece na tv, recebe esse apelido por causa da cor de sua roupa e de sua sensualidade. Enfermeira Nurse - redundância, caso se leve em conta a tradução de nurse, enfermeira em inglês assim é chamada em razão de seu trabalho.

Os personagens indicados - mas sem nome como os tempos e espaços, sem datas e localizações exatas - possuem seus traços físicos e psicológicos indefinidos. Diferentemente da inconização realista, a descrição não revela um conjunto de aspectos como biografia, idades, alturas, pesos, cores, classes, modos de vestir, falar, andar, por meio do qual se definem traços particulares. Em geral, somente um ou alguns elementos dão conta de referir os personagens. Como o espaço que é só a função "boteco", sem que se saiba o tamanho ou o que ele contém, ou as suítes de hotel, que se reduzem a banheira, televisão, cama... os personagens limitam-se principalmente a uma voz pura, a uma bunda gigante, ao hábito de falar demais, à semelhança entre si (trigêmeos), e assim por diante. Quando há maior iconização, ela se dá apenas na medida em que eles interagem com o narrador, sem que essa interação seja suficiente para uma definição não parcial de 
personalidade; como poderia ser caso um diálogo revelasse um conjunto de aspectos como os elencados acima.

O percurso figurativo de tempo, espaço e personagens constitui-se por meio desse modo fragmentário e metonímico. Diferentemente da ação principal, cujo percurso é linear e coeso - o conflito com o ralo, o estabelecimento da relação afetiva entre produtor e cantora, e a escritura do romance são narrados desde de o início até o fim sem hiatos (com exceção de $O$ Cheiro do Ralo) em seu eixo -, tempo, espaço e personagens são mais indicados por alguns aspectos do que construídos em sua totalidade. Assim, a expressão in media, de in media res, seria mais adequada a esses conceitos do que ao de ação. O efeito provocado por esse caráter fragmentário e metonímico é praticamente uma tematização da figura, na medida em que poucos elementos dão conta de construir personagens e lugares típicos. A desiconização, por um lado, oposta à técnica realista, chega, assim, a resultados próximos a ela, já que os lugares e personagens, sejam identificados minuciosamente ou indicados de forma sucinta, adquirem caráter abstrato: representam um tipo.

Tal recurso de desiconização, como o uso predominante do presente indicativo, é também um modo de presentificar. Ao contrário da debreagem, porém, tal procedimento não se faz por meio da relação entre enunciação e enunciado. $\mathrm{O}$ uso de um discurso cujo referente é parcial exige um complemento do enunciatário, semelhantemente à música. Quando o narrador declara o surgimento de uma personagem ou, por meio de algum elemento, indica o espaço, sem iconizá-lo mais densamente; a forma de referir se aproxima à dos dêiticos e assim se estabelece a presentificação, como se enunciador e enunciatário estivessem sempre no contexto de leitura. O uso da palavra "centro" em $O$ Cheiro do Ralo ilustra muito bem essa característica. Aparentemente, centro é icônico: centro da cidade; todavia, seu efetivo referente só pode ser depreendido quando se conhece a cidade da enunciação.

Essa presentificação oriunda da desiconização recai no problema veredictório, cujo efeito de sentido é o de discurso do psicologicamente desequilibrado. As "desconexões" de isotopia de ordem geral - tempo, espaço e personagem -, acionadas principalmente no eixo paradigmático, contribuem na construção da imagem de narradores incompetentes em fomentar um discurso que pressupõe narratários. Selecionando as ações do início ao fim, o narrador dirige o percurso do conteúdo conforme determinada inteligibilidade do 
"destinador coletivo", segundo o conceito de Bertrand. Omitindo grande parte de elementos do contexto dessas ações, contraria tal conformidade, mostrando-se deficitário no conhecimento dos limites entre o saber de quem emite e quem recebe o discurso. Trata-se de uma questão mais profunda a respeito de intero e exteroceptividade; desenvolvida melhor na análise dos romances em separado.

Além desses elementos de ordem geral, há “desconexões” pontuais que aparecem freqüentemente, sobretudo em $O$ Cheiro do Ralo, no qual se encontra o narrador mais perturbado, porque mais inconsciente dos limites de sua percepção. Retomando a breve tipologia de modos de conexão: tem-se, no eixo paradigmático, associações e tematizações (transformações do icônico em abstrato) muitas vezes parciais e incoerentes; e no eixo sintagmático, contradições.

As associações podem ser de conteúdo:

"Penso na bunda. "Rosebud". Se eu morresse agora com Welles, ninguém encontraria meu Rosebud". Se aquela bunda estivesse comigo agora eu ia brincar tanto com ela. Eu brincaria como um garoto brinca com o seu Rosebud." (Mutarelli, 2002: 18)

Nesse trecho, se encontra uma dentre as inúmeras referências ao filme "Cidadão Kane", de Orson Welles, em $O$ Cheiro do Ralo. No longa-metragem, a palavra Rosebud muito provavelmente traz a infância à lembrança do personagem principal. Na passagem acima, o dono da loja de penhores associa a palavra à bunda que se torna idéia fixa. Ambos são refúgios, e essa é a razão da associação. O magnata Kane e o dono da loja de penhores são corrompidos pelo dinheiro; o que traz à imaginação do primeiro um estado de pureza é sua infância; também a pureza é depreendida da bunda pelo narrador.

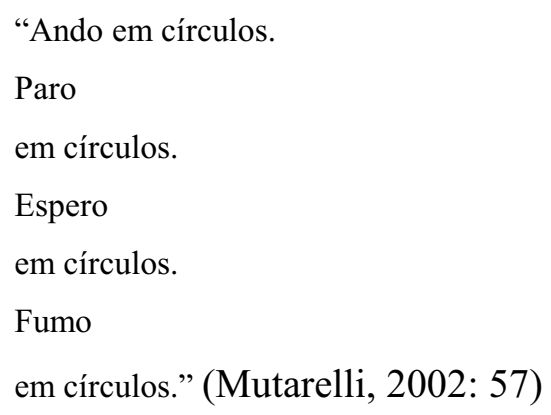


A expressão "andar em círculos", que possui sentido denotativo e conotativo (talvez esperar), é ambivalente na primeira frase, somente conotativa nas duas seguintes; e, de novo, ambígua, na última. Nesse momento, o produtor musical está ansioso, esperando o regresso da Voz. Os círculos que se associam pontualmente nas quatro frases também podem estar associados ao eterno retorno, que é tematizado no romance. De modo que a espera presente relaciona-se com a do passado: a de que a mulher desejada não se entregue ao Maestro, como sua mulher.

"Permaneço em silêncio na tensão de um filme de Alfred Hitchcock" (Mutarelli, 2004: 98)

Trata-se de um diálogo com a obra do cineasta Alfred Hitchcock. A intertextualidade é característica dos romances de Lourenço Mutarelli, principalmente em se tratando de literatura e cinema. O elemento intertextual, do modo como aparece, contribui para o aspecto metalingüístico ainda não discutido. Todavia, levando em consideração que o trecho acima é de Jesus Kid, é possível adiantar que a associação figurativa da realidade vivida pelo escritor e o cinema decorre de seu dever: terminar o roteiro.

As associações no plano da expressão também aparecem freqüentemente:

“Restaurante com vista pro cu. Nada de couvert." (Mutarelli, 2002: 47)

Associação da sílaba "cu” do português com outra de mesma sonoridade da língua francesa.

"Falange, falanginha, falangeta./

Carpo, metacarpo.” (Mutarelli, 2002: 134)

No trecho acima, há associação, na primeira frase, entre palavras cujo radical "falange" aparece recebendo diminutivo e o sufixo "eta"; na segunda, o radical "carpo" ocorre isolado, seguido por uma forma prefixada. Associa-se também no plano do 
conteúdo, já que falange, falangeta, carpo e metacarpo são ossos e conjunto de ossos que compõem a mão e sua articulação com os braços.

"Agora vou ler esta merda! Muito provavelmente escrita pelo Leite. Mas não vou chorar pelo derramado." (Mutarelli, 2004: 157)

Homófonos, "Leite" sobrenome e "leite" bebida se associam.

Outro recurso associativo é o paralelismo sintático, mais recorrente em $O$ Cheiro do Ralo e $O$ Natimorto:

"Ela entra.

Ela treme.

Eu pago.

Ela pergunta pelo olho do meu pai." (Mutarelli, 2002: 54)

Trata-se do paralelismo pronome/sujeito seguido de verbo, repetido nas quatro frases. O objeto indireto da última quebra a homologia por meio de um verbo transitivo.

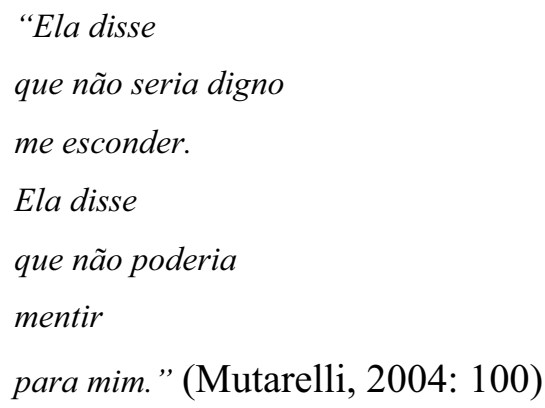

Ocorre repetição da oração principal "ela disse", sendo completada por uma subordinada com advérbio de negação e verbo no futuro do pretérito.

O paralelismo pode ser considerado um elemento importante de composição dos romances de Mutarelli. Em O Cheiro do Ralo, as cenas da loja de penhores e da moradia do narrador-personagem têm, com poucas exceções, quase a mesma seqüência; no boteco, as 
ações também não são muito diferentes. Em O Natimorto, as cenas do hotel também obedecem a certo paralelismo, na medida em que, as cenas principais são marcadas pelo acordar e dormir do narrador-personagem e os subseqüentes atos de verificar a advertência do cigarro e fumar. No caso de Jesus Kid, as aparições do personagem de western podem ser consideradas marcas de paralelismo.

Em se tratando do primeiro romance, há um recurso associativo de suma importância: a paródia explícita. No trecho seguinte, a paródia é da famosa canção “Águas de março”, de Tom Jobim:

“É verdade, é mentira, é boato.

É cabide, é bidê, é o fim do caminho.

É pau, é pedra.

É farinha, é pó, é o talco". (Mutarelli, 2002:139)

Em princípio, a associações, sejam de conteúdo ou expressão, simples projeções do eixo paradigmático no eixo sintagmático, não configuram necessariamente a imagem do desequilíbrio psicológico, nem mesmo na prosa. Há muitos romances, como Grande Sertão: Veredas e Vidas Secas, nos quais tal artifício recorre de modo a estabelecer imagens completamente diferentes. A particularidade dos romances de Mutarelli, no que diz respeito a esse aspecto, está envolvida com o fato de que as associações são, freqüentemente, despropositadas (como é exemplo o tarô) ou sem vínculo importante com a totalidade do texto - criando desvios de sentido.

Em alguns momentos, tais recursos associativos podem ser considerados uma propensão maníaca dos narradores. Há passagens, em que eles mesmos indicam a insistência em associar significantes, significados ou dar segundo sentido à relação entre as figuras do mundo natural:

“O pão de forma mofou. Pão deforma. Associo." (Mutarelli, 2002:41)

"Fito os padrões do tapete. Estranhos padrões. Talvez, advertências.

Procuro, em vão, decifrar os padrões." (Mutarelli, 2002: 25 e 43) 


\begin{abstract}
"Esse pequeno e tolo incidente acabou me tirando o sono... E se for verdade? E se existir realmente um chinês refém de seu restaurante? Como eu, prisioneiro. Penso no chinês procurando traduzir sua dor no dicionário Chinês-Português. Longe de sua família, um descrente chinês condenado a escrever mensagens de esperança. Como eu, condenado a escrever." (Mutarelli, 2004: 94)
\end{abstract}

Em O Cheiro do Ralo, O Natimorto e Jesus Kid, respectivamente, por meio das palavras "associo", "decifrar", "penso" e "como", o exercício constante de associação feito pelos narradores é declarado. No primeiro trecho, a questão é meramente fonológica, contudo, indicativa de uma operação lingüística, cujo sentido só pode ser vinculado à totalidade do texto, se se levar em conta a construção do ethos de desqeuilíbrio. No segundo, a mania de interpretação se estabelece na constante tentativa de o narrador encontrar significado no "padrão" visual do tapete do hotel. No terceiro, o recebimento da mensagem "Me ajudem! Estou preso no porão do restaurante. Eles querem me matar." enseja a configuração imaginária de uma cena enunciativa, por meio da qual se constrói um enunciador (o Chinês) e um percurso narrativo (seqüestro, produção de bilhetes manipulação, performance).

Os dois últimos trechos associam-se também à situação do narrador; com a palavra "advertências", que denomina as cartas do "tarô" e a comparação explícita, em Jesus Kid, do estado em que se encontra o Chinês com a condição de escritor encomendado. A decifração do tarô, da mesma forma que o sentido atribuído à bunda e ao ralo, manifesta a mania associativa, a necessidade ou vontade de depreender isotopias.

A construção figurativa de $O$ Cheiro do Ralo e de $O$ Natimorto é composta e interpretada simultaneamente. Segundo o ponto de vista dos narradores, a oposição entre ralo (inferno) bunda (paraíso) compõe os conflitos principais no primeiro romance; no segundo, a direção dos acontecimentos é definida pela lógica temática das figuras do tarô de maços de cigarro. Ambas isotopias são irregulares (nem sempre conectáveis) e absurdas na medida em que o campo figurativo tem efeito de sentido não de fantasia, mas de realidade desiconizado por meio daquela. $\mathrm{O}$ caráter inverossímil dos pontos de vista dos narradores ganha ainda mais sustento nas declarações dos outros personagens a respeito deles. Em todos o casos, se mencionam internação, medicação ou tratamento. 
Diferentemente da conexão metafórica que se dá em $\mathrm{O}$ Natimorto, o trecho selecionado de Jesus Kid associa a situação do Chinês com a do escritor por meio de comparação, utilizando a conjunção "como". Nos dois primeiros romances, as associações mais importantes se acionam com o uso de conectores de isotopia que não explicitam o processo associativo. No último, porém, são mais freqüentes comparações explícitas e palavras que separam o plano de leitura original e o originado; tais como o verbo “imaginar". Isso se deve ao fato de que, além de a consciência do narrador ser maior do que a dos outros, discernindo melhor realidade de imaginação (segundo o construto figurativo), a principal isotopia - a escritura do roteiro, organizadora dessa experiência, já que é texto sobre o processo de produção - é imposta, nitidamente por atores, sujeito manipulador, que não coincidem com o do ser. No trecho abaixo, aparecem tanto o compromisso em constituir uma isotopia que dê conta dos elementos reais e sugeridos pelos produtores quanto a resistência do narrador em fazê-lo:

“O desespero acelera o relógio. A minha incapacidade de combinar elementos. Dor criativa, hotel, musa com lira, halteres, Melissas e Pin-ups, favela e prisão domiciliar, com batatinhas chips... Fazem o dia voar." (Mutarelli, 2004: 92)

Outro dado recorrente e que contribui para construção da imagem do desequilibrado são as compulsões. Em cada um dos três romances, o narrador sofre de alguma compulsão que aparece em quase todo decorrer do texto. Em $O$ Cheiro do Ralo, é a atribuição de preço, que faz parte do trabalho, mas não se restringe a ele. Em O Natimorto, é a necessidade de fumar cigarros, cuja embalagem contribui na construção figurativa do tarô. Em Jesus Kid, é o consumo de medicamentos, necessários toda vez que o narrador personagem se sente ameaçado.

A fim de depreender o ethos do desequilibrado, esta pesquisa restringe-se aos aspectos textuais da obra analisada. Apesar de se reconhecer sintomas passíveis de diagnose pela psiquiatria e psicologia - como a compulsão (“Compulsão a repetição”, de Freud) em atribuir valor de compra e em tomar medicamentos freneticamente - permeando os romances de Mutarelli, optou-se pelo não acionamento de teorias dessa área no que diz respeito à possível moléstia da síndrome do pânico. Isso porque parece não haver uma definição geral da doença, diferente do uso corrente do termo, que possa ser prolífica na 
análise. A maioria das pesquisas dessa área atém-se, sobretudo, a relatos e análise de casos, sem que haja uma conceituação mais genérica cujo acionamento pudesse auxiliar na análise de figuras ou temas relacionados à paixão do pânico.

Há, todavia, um discurso vinculado ao saber psicológico, na medida em que, por exemplo, um trauma origina um distúrbio e em que aparecem, de alguma forma, os conceitos de projeção e transferência, elaborados nas pesquisas de Freud. Constantemente, os narradores transferem modos de agir e sentir, como o produtor que interpreta sua relação com a cantora tal qual a que teve junto à ex-esposa. As projeções vão desde o ralo que, segundo a visão do dono da loja de penhores, adquire qualidades suas, ao alter-ego Jesus Kid, criado pelo personagem escritor. Apesar disso, como esses conceitos não são aprofundados conforme no discurso psicanalítico, são utilizados os desenvolvimentos teóricos realizados por Bertrand no que diz respeito ao caráter transformador do sujeito patêmico em relação ao mundo que o cerca.

É necessário salientar que essa interdiscursividade com as teorias psicológicas difere bastante da surrealista, talvez a mais consagrada. No Surrealismo, além da inspiração em temas e figuras dos textos de Freud e outros teóricos; sobretudo a poesia, com a técnica (ou efeito de sentido de técnica) da escrita automática, constrói a imagem de enunciador cujo inconsciente enuncia com a mínima interferência do consciente. Os personagensnarradores de Mutarelli não cumprem o papel discursivo de liberação do inconsciente; têm sua consciência sobredeterminada por ele em razão de um desequilíbrio constitutivo. A despeito da história de efeito autobiográfico de Transubstanciação, esse desequilíbrio compõe o ethos dos narradores, enquanto o enunciador mantém distanciamento crítico por tal razão é que se distinguem, neste trabalho, os conceitos de narrador e enunciador. 


\section{O CHEIRO DO RALO E LÍTOTES}

Por meio de coerência e coesão, o sentido de um texto é composto pela relação entre as partes e o todo; de modo que nenhum elemento pode ser compreendido sem haver conhecimento geral do objeto do qual faz parte. Como os outros gêneros, o romanesco, obedecendo a uma lógica argumentativa, possui especificidades. $O$ trabalho com a função poética e a instauração de um narrador são algumas delas.

De forma semelhante ao gênero dissertativo, por meio do qual, dentre algumas possibilidades, geralmente, a introdução apresenta o tema que a conclusão sintetiza; na forma romanesca, início e fim costumam estar ligados por relações determinadas e, que, muitas vezes, podem coincidir com apresentação e síntese.

No início de $O$ Ateneu, por exemplo, há uma apresentação tanto figurativa quanto temática. Apresentam-se personagens pai e filho, e o cenário onde a maior parte da narrativa transcorre. A frase "vais encontrar o mundo" anuncia que as experiências passadas naquele local são representativas da vida como um todo: a entrada no Ateneu equivale ao início da constituição de uma autonomia individual. A seguir, o narrador passa a um discurso mais temático, no qual discorre sobre a essência da vida, mera passagem do tempo, causadora de uma série de decepções.

O romance termina com o incêndio do Ateneu, e a retomada do tema de que a vida é mera passagem do tempo; não só decepcionante, mas cheia de perdas:

"Saudades, talvez, se ponderarmos que o tempo é a ocasião passageira dos fatos - mas sobretudo o funeral para sempre das horas". (Pompéia, 1990:183)

A abertura de $O$ Cheiro do Ralo parece anunciar um percurso narrativo decisivo. É colocado à venda um relógio cujo antigo dono, segundo quem oferece, é Soran insistentemente caracterizado como um anagrama, originado do nome de um sábio. $\mathrm{O}$ dono da loja de penhores se recusa a comprá-lo, e o sub-capítulo termina com o seguinte trecho:

"Ele falou que eu não estava entendendo a oportunidade que se abria para mim. Ele falou que a sorte abre suas portas para todo mundo, pelo menos uma vez na vida, mas que se esta oportunidade é desperdiçada, a sorte cerra suas portas. 
Tendo em vista a importância do momento em que se encontra essa ação, considerase que não se trata apenas de um percurso de manipulação por intimidação e tentação cujos efeitos o destinador (dono da loja de penhores) julga falsos ou mentirosos. O modo de disposição dos acontecimentos numa narração tem efeito de sentido; e esse último possui relação direta com os usos freqüentes e consagrados das técnicas narrativas.

Logo no início do romance, estão a proposição de decifração de um anagrama e a compra de um relógio que serviria de caminho à felicidade. A associação entre a porta metafórica e a denotada, uma cerrada e outra batida, acentuam o efeito de sentido de saber do narrador-personagem, que, com seu gesto, termina o diálogo concomitantemente ao capítulo - uma característica quase profética, na medida em que, poeticamente, determina o tempo da narração.

A construção dessa cena no capítulo inicial provoca uma espera no leitor, pois, imaginando que o anagrama e o relógio são decisivos, é levado a um querer-saber: a medida da importância desses elementos, se o julgamento mostrado pelo cliente a respeito deles condiz com a verdade, se o destinador competente é o narrador-personagem (que julga ser falso o relógio poder coloca-lo em conjunção com o objeto de valor), ou se ambos estão equivocados. De qualquer modo, a construção figurativa parece essencial ao fio condutor da narrativa. Como a apresentação de espaço e atores se dá por meio de um acontecimento que sugere um percurso narrativo no lugar e com o personagem principais do romance, espera-se que esse acontecimento seja fundamental.

Todavia, não parece ser assim. Não há nenhum reencontro decisivo entre o dono da loja de penhores e o vendedor do relógio por meio do qual se possa afirmar categoricamente seu valor efetivo. A cena de início, com elementos figurativos que apontam para uma correspondência temática (analogamente a $O$ Ateneu) e um percurso narrativo centrais, é somente retomada em meio às concatenações do narrador. Na primeira ocasião em que isso ocorre, o narrador-personagem re-elabora a profecia do cliente e esboça a decifração de um novo anagrama, originado da distorção do anterior, imaginando que é o mesmo: 
"Parece que desde o dia que recusei o relógio, a porta da sorte se fechou para mim. Ele disse que o nome do dono era um anagrama. Ziran?

Será que é Ziran. Acho que era isso mesmo.

Ziran é nariz ao contrário.

Nariz tem tudo a ver com cheiro. O Cheiro do Ralo. Bem que ele podia voltar e trazer o relógio.

Com o relógio e o olho, nada podia falhar." (Mutarelli, 2002:34)

No trecho acima, há aspectos que favorecem a expectativa de continuidade e importância da cena inicial e outros que rompem tal isotopia, cuja configuração depende dos modos cristalizados de operar literariamente. A afirmação de que a vida do vendedor da loja de penhores está correndo como havia profetizado o cliente vem a confirmar as decisivas decorrências do encontro entre os dois e a recusa da compra. Contudo, a troca do anagrama, de Soran para Ziran, invalida em alguma medida esse caráter decisivo.

Tomado em sua importância profética e no seu provável envolvimento com o eixo narrativo, o diálogo de abertura, em cada detalhe, tem potencial de relevância; assim como, em $O$ Ateneu, o aviso que o iguala ao mundo e as discussões sobre a vida dão sustentáculo ao romance, sendo retomados ao fim. Por esse motivo, a displicência do narrador em relação ao anagrama interfere consideravelmente na confiança que lhe é dada e, por conseqüência, no julgamento a respeito do que é narrado, segundo modos tradicionais de operar a narrativa.

Trata-se de um problema de veredicção. Depois de trocadas as letras do enigma - de forma que ele perde completamente o sentido -, não é possível ter certeza de qual versão das duas é a verdadeira; se o lapso de memória ocorre na primeira ou na segunda vez em que elas aparecem. Levando em conta o fato de que o elemento esquecido, além de importante, é fácil de ser lembrado, não há como se ter certeza também se o episódio que dá ensejo ao conhecimento do anagrama é verídico.

A escolha da primeira pessoa do singular para o narrador da história pode ser considerada um recurso de subjetivação, que, em última instância, tem efeito de sentido de relativizar a verdade por meio de um ponto de vista assumido. A mudança das letras do anagrama acentua o grau de relatividade, na medida em que, num primeiro momento, parece constituir a imagem de um narrador "esquecido", e, portanto, subversor do real por conta de sua incompetência cognitiva, figurativizada pelo lapso de memória. 
Como o trecho inicial aciona uma isotopia temático-figurativa de continuidade entre começo, meio e fim - instaurada pelo contexto literário, no qual o uso de certos recursos impõe modos de leitura -, desestabilizada depois pelo lapso, é possível afirmar que a incompetência do narrador se estende ao fazer poético. Os códigos literários, cristalizados pela tradição, podem, a qualquer momento, ser desestabilizados ou sofrer anulações por causa de sua displicência. A reiteração da isotopia destacada contribui para esse efeito de sentido.

Adiante no romance, um cliente entra na loja de penhores e pergunta se o dono consegue lembrar-se dele. Sem explicitar e saber exatamente o motivo, o narradorpersonagem o agride; e em meio à briga, ouve seu adversário referir-se a um relógio trazido por ele noutro dia. Por conta da seqüência narrativa, parece que se trata do cliente de início e que, mais uma vez, o caminho da felicidade é recusado. Todavia, a conjectura não pode ser uma afirmação categórica, já que a displicência de fazer poético permite a colocação de dois elementos que acionam uma isotopia sem que ela seja efetiva.

Também a falta de credibilidade do narrador impossibilita a apreensão do real não modificado pelo ponto de vista. De modo que não há como se certificar de que a briga ocorre e se ela ocorre tal qual se narra; não é possível certeza, principalmente, de que o relógio é mencionado ou não. O próprio narrador-personagem confirma o caráter impreciso de sua percepção, quando se refere ao ocorrido:

"Eu trouxe o relógio outro dia. Algo assim ele grita.

Não entendo.

Na hora não entendo o relógio." (Mutarelli, 2002: 58)

A frase que sucede a primeira torna frágil seu grau de precisão. "Algo assim" explicita um referente inexato. "Não entendo" contribui para o mesmo sentido, que é amenizado pela locução adverbial "na hora". Esses três elementos indicam, além da percepção imprecisa, a incompetência do fazer poético. Novamente, uma cena de importância, composta por figuras que retomam o início do romance, é enunciada sem a devida precisão; como se a isotopia formada não tivesse relevância. A seqüência das duas últimas frases "revela" o percurso de composição do trecho, já que, tendo em vista o que se poderia interpretar da anterior (o narrador não entende a situação em que se encontra), a 
última é uma reformulação mais precisa. O modo como é inserida a fala do cliente contraria o uso tradicional do discurso direto livre, justamente porque, nessa modalidade, o efeito de sentido é de precisão.

Há outra passagem fundamental para o entendimento da isotopia constituída entre os episódios relacionados ao relógio e ao anagrama, e a forma como ela é desestabilizada. Numa passagem, o dono da loja de penhores adquire o telefone da "bunda", liga, e seu pai atende, dizendo que ela não está. A partir dessa experiência, uma série de associações se concatena até que se retome a figura do relógio e a briga com o cliente que, a partir da impressão do narrador, se supõe tratar-se do mesmo da cena inicial e talvez o homem do telefone:

"Ela deve estar num ônibus. Num ônibus lotado. Lotado de gente cansada. Gente que foi trabalhar. Deve haver, nesse ônibus, pelo menos uma pessoa que já procurou meus serviços. Talvez, seu próprio pai. Talvez o seu próprio pai tenha ido no meu escritório, e quem sabe eu não o tratei bem. Quem sabe eu mandei o imbecil do segurança, notar ele para fora. Quem sabe o pai dela era aquele que eu cobri de pancada. Quem sabe o pai dela não me procurou, tentando vender um relógio. Um relógio que ganhou de alguém. Alguém cujo nome era um anagrama. Ou então ele foi lá me vender um olho.” (Mutarelli, 2002:109)

O imaginário do narrador-personagem constrói um enredo no qual a isotopia ganharia estabilidade. Há uma espécie de promessa de fechamento, tal qual a retomada do fim de $O$ Ateneu, e a síntese de uma dissertação. Se, de fato, o pai da "bunda" fosse o cliente que oferece o relógio duas vezes, o primeiro episódio e o da briga estariam ligados pelo enredo. A recusa insistente estaria mais perto da negação da felicidade, na medida em que comprar o relógio talvez o aproximasse de alguma forma da mulher desejada, que é referida pelo narrador como "salvação".

Entretanto, todo esse arranjo não passa de mera conjectura, o que pode ser depreendido da frase que encerra o trecho, na qual outra concatenação imaginária é efetivada: o pai, dessa vez, é o vendedor do olho de vidro, ao qual o narrador-personagem atribui uma série de qualidades e valores. O processo é semelhante ao suposto desvendamento do anagrama, que a memória assumidamente falível transforma de Soran para Ziran, relacionando-o com nariz, cheiro e, por último, ralo. 
A figura do ralo é a mais importante do romance, sobretudo porque lhe dá o título. Centro de grande parte dos questionamentos, suas funções podem variar de representante da própria essência do narrador-personagem (como um espelho) a anti-sujeito. Levando em consideração essa última atribuição e o fato de que ela passa a ser predominante em grande parte do texto, é possível entender que talvez a compra do relógio livrasse o dono da loja de penhores dos problemas futuros, e centrais, em relação ao cheiro e a iminência de vazamento do ralo. O poder-fazer e o fazer do ralo, porém, limitam-se ao imaginário; e mesmo que assim não o fosse, a figura do relógio e o fato de não existir nenhum sábio consagrado de nome Ziran tornariam a isotopia frágil, já que a profecia - além de não ser cumprida no "mundo real” -, é alicerçada por enigmas (com prováveis funções modais) que não desvendáveis até o final do texto.

Outra possibilidade isotópica é a de o anagrama correto ser o primeiro: Soran. Nesse caso, a palavra que pode estar cifrada é "março"; estritamente por conta dos exatos fonemas que se correspondem. "Março" está no título da canção "Águas de março", de Tom Jobim, da qual a intertextualidade é marcada por uma paródia, citada no capítulo anterior. A relação intertextual não se limita ao plano de expressão; o tema do ciclo (essa é a palavra utilizada no romance) coincide nos dois textos; e a figura do relógio, por causa de seu vínculo com o tempo, fortalece a possível isotopia.

O ciclo, figurativizado pelo caráter anafórico dos sub-capítulos, passível de ser depreendido das cenas de compra e venda na loja de penhores, dá nome ao capítulo em que justamente se encontra a briga. Todavia, como a identificação do segundo vendedor de relógio com o cliente do episódio inicial é mera suposição, o caráter cíclico dessa ação não pode ser considerado efetivo senão no âmbito imaginário. No que diz respeito ao outro acontecimento relevante no capítulo em questão não há nenhum elemento figurativo que esteja associado diretamente ao tema do ciclo. Trata-se do recebimento de uma caixa, na qual há um sapo utilizado como uma espécie de macumba, pois, dentro de seu estômago, há um pedaço de papel em que está escrito: "estive no inferno e lembrei de você".

A despeito de não corresponde a um fio condutor, o capítulo termina com um parágrafo cuja síntese é a de que "a vida é um ciclo": 
quando estão todos contra mim. O telefone toca. Atendo antes mesmo disso. Alô? Digo eu. Do outro lado ninguém. Ninguém fala nada. Ninguém fala nada com nada. Eu estive no inferno e me lembrei de você. Depois de dizer isso, desligo. Você está sentido isso também. Pergunto ao olho. Ele confirma. Ando lentamente até o banheiro. Ele me achou. O cheiro sobe do ralo. $O$ cheiro me infesta o nariz. Aspiro. Aspiro fundo. Algo ou alguém passa rapidamente atrás de mim. Viro de forma instantânea. Só dá tempo de captar o vulto.

A vida é um ciclo." (Mutarelli, 2002: 74)

Esse trecho torna mais claro um dos processos de composição de $O$ Cheiro do Ralo, onde, de modo semelhante aos episódios em que reaparecem as figuras do relógio e do anagrama, se utilizam certos recursos literários, instaurando e desestabilizando um significado. O título "ciclo", que, tomando por base as formas literárias tradicionais, deveria dar conta do conteúdo do capítulo, não cumpre essa função. Isso porque, do episódio mais importante, por interferir em ações futuras no romance, que é o recebimento da macumba, ele não pode ser depreendido nem como tema, nem como figura. No que diz respeito ao outro fato relevante, a briga, o cíclico é apenas uma conjectura.

O último parágrafo do capítulo, portanto, cumpre papel de síntese ou de fechamento de um conteúdo cujo eixo principal não condiz com o título. Nele, semelhantemente à ameaça de fechamento imaginário da isotopia instaurada pela cena inicial, a retomada de figuras e percursos aparentemente fundamentais, seguida da frase de encerramento, colocase na condição de simulação ou mentira, na medida em que parece, mas não é, segundo o quadrado semiótico desenvolvido a partir da categoria semântica ser x parecer:

\section{(Verdade/Evidência)}

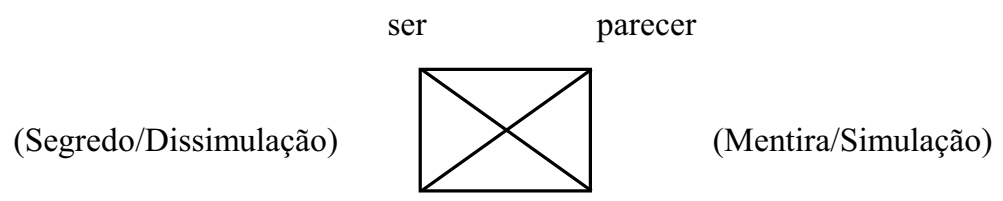

não-parecer não-ser

(Falsidade/Não-pertinência)

(Bertrand, 2003:243) 
Além da frase final, a simulação de fechamento se dá por meio da junção de figuras importantes como se elas compartilhassem de uma mesma isotopia cujo sentido maior seria o "ciclo". Há o telefonema silencioso, aparentemente da ex-namorada, para quem o narrador-personagem telefona constantemente sem dizer nenhuma palavra, o ralo e o vulto. Como os dois últimos elementos passam da ausência para a presença no enredo - o dono da loja de penhores decide desobstruir o ralo, antes acimentado; e enxerga o vulto depois de algum tempo sem o fazer -, é possível se falar em retorno, mas não em ciclo, na medida em que a definição de um ciclo depende de mais de uma repetição.

$\mathrm{Na}$ verdade, a frase "a vida é um ciclo" cumpre função de incentivo, pois mais serve para apoiar a desobstrução do ralo do que representa uma constatação a respeito da realidade. Levando isso em conta, pode-se entender o episódio da briga como um segundo motivo para que seja re-estabelecido o contato entre o narrador-personagem e o cheiro do ralo. Por causa desse valor motivacional, que é possível considerar como uma sobredeterminação do saber pelo querer, já que a realidade percebida tem a interpretação dirigida pelo desejo de entrar em conjunção com o ralo, há novamente o problema da veredicção.

No que diz respeito à fragilidade veredictória, cujo efeito de sentido é de verdade distorcida, o parágrafo conclusivo do capítulo apresenta alguns elementos que colaboram em sua criação. O problema de coerência lógica de atender ao telefone antes de ele tocar serve como exemplo. O diálogo com o olho, que não é um ser efetivamente animado, a visão do vulto e a declaração, entre a prosopopéia e a insanidade, de que o cheiro "achou" o dono da loja de penhores indicam a não veracidade dos acontecimentos narrados.

Portanto, mesmo no caso de "Soran" (relacionando-se a "março", cuja associação ao tema do ciclo é dada por meio de intertextualidade) ser a palavra proferida pelo primeiro cliente a oferecer o relógio, a cena de abertura contraria a estabilidade de certos recursos literários e coloca em questão a validade da história narrada. Outra passagem que contribui para esse efeito de sentido se dá quando o dono da loja de penhores tenta transformar a frase dita pelo cliente da briga em anagrama:

"Pego uma esferográfica azul. Igual a que o Steve assinou. Ando até Rosazul. Faço bigodes. Faço cavanhaque. Pinto um dente também. Vou para o quarto.

EU TROUXE O RELÓGIO OUTRO DIA. 
Talvez fosse Ziran.

Deito.

EU TROUXE O RELÓGIO OUTRO DIA.

Ai dor tu o oi gole ro exu or tu é.

AI DOR, TU O OI. GOLE RO EXU OR TUÉ.

Ai dor, teu olho. Um gole pro Exu que tu és." (Mutarelli, 2002: 60)

A mania por associações, sejam de plano de conteúdo ou de expressão, dos narradores de Lourenço Mutarelli está apresentada no capítulo anterior desta dissertação. Em $O$ Cheiro do Ralo, ela é mais recorrente do que nos outros romances. Principalmente nele, certas associações, que parecem fazer parte da realidade externa ao narrador, correspondem apenas a seu imaginário.

No trecho acima, a mania associativa manifesta-se especificamente na modalidade dos anagramas; em conjunto com a seqüência da narração, enseja a desconfiança quanto à veracidade e importância do episódio de abertura. Logo em seu início, o narradorpersonagem apresenta o ethos desequilibrado, quando, aparentemente sem motivo, desenha bigodes e cavanhaque num quadro que possui. Entende-se que, em seguida ao desequilíbrio psicológico mostrado, o pensamento fixa-se na frase dita pelo cliente da briga, tentando encontrar nela um sentido maior. É assim que, lida ao contrário, origina: "ai dor tu o oi gole ro exu or tu é". Tal seqüência, além de agramatical, possui apenas as palavras "o", "dor", “tu”, “oi”, "gole”, “exu” e "é" - no português. Sem nenhuma lógica rigorosa, a não ser o desejo de encontrar algum sentido, o narrador constrói "Ai, dor, teu olho. Um gole pro Exu que tu és.”; o que, apesar de unir olho e Exu (entidade também ligada ao inferno, figura recorrente no texto) e o grande esforço de atribuição de significado, não estabiliza uma isotopia regular.

Trata-se de um modo interpretativo de o narrador organizar a realidade exterior e, que, muitas vezes, é ambíguo no que pode ser considerado real ou imaginário. Como por exemplo, os vultos, que são vistos pelo personagem principal e por sua faxineira, podendo ser meras coincidências; e a proposição do anagrama, que pode ser real ou imaginária, sem que se possa descobrir exatamente. Essa desestabilização veredictória é indicada, logo em seguida à reformulação da frase do cliente da briga, quando o narrador aplica-a à sua realidade após afirmar que suas idéias estão sob "a mecânica dos sonhos": 
"A mecânica dos sonhos.

É assim que se compõem.

Eu causo a tua dor.

Eu e o meu olho.

Bebo.

Bebo o teu sangue.

Sou o Exu.

Sou o mal.

Invento o meu sonho." (Mutarelli, 2002: 60)

Por meio de associações, a frase dita pelo cliente se transforma em anagrama e afirmação de que o narrador-personagem está ligado ao inferno; ligação essa que pode ser encontrada mais de uma vez no romance, inclusive quando o ralo é identificado como um portal para o inferno. Esse percurso sustenta figurativamente o episódio que vem logo em seguida: o recebimento do sapo com o pedaço de papel no qual se lê a sentença "estive no inferno e lembrei de você".

Tal procedimento, além das transformações figurativas, implica mudanças no que diz respeito à credibilidade do narrador. A aparição de um outro cliente, oferecendo um relógio, e se referindo a outro dia em que estivera presente na loja, é mais verossímil do que sua associação com o cliente da cena de abertura; principalmente, se for levado em conta o fato de que não é explícita, mas indicada por recursos literários. Ou seja, o dono da loja não declara a associação, não se lembra ou faz referência a nenhum aspecto físico de nenhum dos dois personagens, e ainda o agride, sendo impossível ter certeza do que o coloca em conjunção com esse querer-fazer.

A associação mostrada, depreendida da tentativa de atribuir um caráter anagramático à frase do possível vendedor do relógio de Soran, desestabiliza ainda mais a persuasão do narrador, na medida em que sua competência cognitiva, modulada por meio de crer e saber, parece tomar o imaginário como real. O limite desse percurso crescente de desestabilização da credibilidade está no momento em que o personagem principal se identifica com "Exu"; e, logo depois, afirma inventar seus sonhos, mesmo reiterando inúmeras vezes sua incapacidade de sonhar. 
É possível discernir graus de verdade do narrado, que correspondem aos graus de persuasão: quanto mais persuasivo for o discurso, mais verdadeiro o referente, e vice-versa. A relação se dá, portanto, entre "o mundo natural” e o ponto de vista do narrador; cognição narrativa erigida literariamente, e construção figurativa. O título "O Cheiro do Ralo" é bem sintético no que diz respeito a essas medidas. O ralo fétido e prestes a transbordar é elemento verossímil; contudo, as atribuições actanciais e de valores, as associações figurativas, que o tornam central, transformam seu modo de ser, na medida em que sempre é dado pelo narrador, na instância do absurdo. Seu vínculo com o real é estabelecido pela unanimidade dos personagens que também possuem relação sensória com esse objeto, olfativa ou visual; por exemplo, ao declararem sentir o mau-cheiro. O caráter imaginário é mostrado pela compulsão a associações e constituições de isotopias do narrador, e também pela unanimidade dos outros personagens, dessa vez, em não encontrarem sentidos outros ao ralo, senão os que lhe conferem o modo de ser de um objeto inanimado do mundo natural. Segundo as reações do narrador-personagem o ralo de sua loja e, vez ou outra, o de sua casa, possuem característica especiais que o tornam diferente dos outros; para seus interlocutores, trata-se de um ralo como outro qualquer. $\mathrm{O}$ mesmo ocorre com a bunda, o olho, e outros objetos que aparecem em meio à narrativa.

Além dos outros personagens, o que alicerça o construto de real, em oposição, a imaginário é o que Bertrand denomina "destinador coletivo". Como não é possível analisar uma figura isolada das outras às quais se articula, é necessário que se entenda a última, para analisar pontos mais específicos. Numa obra literária, como no exemplo dado do Naturalismo, no capítulo anterior, o entendimento das figuras no todo e suas partes é dado conforme esse destinador coletivo, cuja abstração se faz a partir da tradição literária.

$\mathrm{Na}$ composição de $O$ Cheiro do Ralo, se encontram espaços do meio urbano, como: loja de penhores, moradia, consultório, boteco, banca de jornal, loja de conveniência. Os personagens também fazem parte desse meio: dono da loja de penhores, garçonetes, clientes, etc. Levando esses elementos em consideração, pode-se dizer que o campo figurativo do romance não se afasta muito do realismo na medida em que as figuras podem ser encontradas no chamado mundo natural. O que seria diferente, caso houvesse seres ou lugares mitológicos, como anjos, fadas, elfos ou florestas encantadas, o Paraíso, o Hades etc. São possibilidades figurativas que, no período atual, fazem parte do fantasioso ou 
fantástico. Mesmo havendo a densidade figurativa atribuída ao Naturalismo por Denis Bertrand, o dado imaginário persiste quando as figuras não fazem parte do real, segundo a cultura de determinada sociedade.

Se o modo de referência mais icônico opõe-se ao abstrato pela forma de referenciar figuras; talvez seja possível reutilizar essa oposição no que diz respeito às figuras selecionadas. Fadas, elfos, deuses, florestas encantadas ou o Paraíso se aproximam do abstrato e do temático, na medida em que podem ser consideradas idéias. Cidade, loja e boteco, independentemente de sua densidade figurativa, se aproximam do icônico, já que a percepção do destinador coletivo mantém contato com sua concretização também fora do contexto da fantasia.

As relações lógicas entre as figuras contribuem para os efeitos de real ou imaginário. Há uma logicidade culturalmente construída para se entender o mundo natural, talvez "o reconhecimento sintetizado" que Bertrand define, com auxílio de conceitos de Merleau-Ponty e Husserl:

\footnotetext{
“'Abaixo das percepções propriamente ditas existe portanto, para subetendê-las, uma função mais profunda sem a qual aos objetos percebidos faltaria o índice de realidade [...] e pela qual os objetos passam a contar ou valer para nós'. Essa função é o 'movimento que nos instala no mundo antes de qualquer verificação', operando o que Husserl já chamava, conforme vimos, de função figurativa. As apreensões fragmentárias da percepção (os "esboços”) são unificadas são as "animações de esboços" -, permitindo o reconhecimento sintetizado dos objetos por meio do aparecimento das formas, linhas e cores." (Bertrand, 2003: 250)
}

É possível encontrar narrativas nas quais o real é desestabilizado por questões de lógica entre os elementos, e elas podem ser chamadas incoerência (motivadas ou imotivadas, conforme a competência do enunciador). Em Memórias Póstumas de Brás Cubas, o fato de a narração ser feita por um personagem morto rompe com a coerência do gênero realista. Em $A$ metamorfose, de Kafka, as figuras e relações lógicas realistas são desestabilizadas pela transformação do personagem principal em inseto (acontecimento tão imaginário quanto a presença de elfos). Apesar disso, a logicidade e as outras figuras mantêm uma isotopia predominantemente realista; e assim pode se considerar acertada a 
classificação "realismo fantástico". O exagero é que desestabiliza a figuratividade realista de $O$ Processo, na medida em que a opressão do judiciário é idealizada.

Levando em consideração os argumentos acima, se determina, em $O$ Cheiro do Ralo, uma isotopia mais próxima do realismo: com figuras icônicas articuladas conforme a coerência exigida por elas. Tem-se, segundo ela, um perturbado dono de loja de penhores, que larga a namorada, com quem estava prestes a se casar, e se apaixona por outra, motivado pela fixação por sua bunda. Essa é uma das intrigas centrais que sustentam o enredo. Paralelamente, o narrador-personagem, em seu trabalho, atribui preços aos objetos oferecidos pelos clientes para serem empenhados. Por conta de sua posição, expande sua qualidade de destinador, e manipulador, chegando a oferecer dinheiro em troca de nudez $\mathrm{e}$ favores sexuais de mulheres que aparecem em sua loja. Ofendida, uma delas, o assassina por vingança. E essa é outra ação central do enredo, cuja última transformação do percurso, a disjunção do dono da loja de penhores com a vida, marca o fim do romance.

Uma segunda isotopia é a que elabora e tenta decifrar anagramas; associa o ralo a um portal do inferno; a bunda, a salvação; o olho, à figura do pai, do diabo e de David Bowie. Ela se constitui por meio da desiconização, que também resulta do rompimento da coerência, dando origem à esfera do imaginário. Diferentemente do realismo fantástico de Kafka, contudo, em $O$ Cheiro do Ralo, as isotopias de realidade e imaginação se separam, de modo que esta é interoceptiva e aquela, exteroceptiva. $\mathrm{O}$ mecanismo figurativo que possibilita a distinção das duas, além do ponto de vista dos outros personagens, é a construção de um realismo não modificado pelo imaginário, a não ser na interoceptividade do narrador-personagem. Se em A metamorfose o novo modo de ser de Gregor Samsa afeta todas as figuras que compõem o romance, os modos de ser irreais do ralo, bunda ou olho, são mostradamente atribuídos pela percepção do personagem central, já que a relação delas com as figuras restantes, na lógica da exteroceptividade, é a mesma antes ou depois das transformações. Outro aspecto que contribui para esse efeito de sentido são as mudanças freqüentes em modalizações e funções dessas figuras, sem um motivo que não seja um dado interpretativo do real. Isso ocorre com os três elementos apresentados acima. Os seguintes trechos ilustram alguns percursos:

"O olho amplifica meu poder." (Mutarelli, 2002: 34) 
“Eu já sei o que aconteceu. Não foi culpa do olho. Coitado. É que eu andava estressado. Por isso eu absorvia o sentimento das coisas. Porque tudo o que eu compro, tem história. Tem sentimento. E eu, cansado, acabava os absorvendo para mim. É como no caso do olho. Coitado. Não era ele quem me trazia má sorte. Eram os sentimentos contidos nele." (Mutarelli, 2002: 45)

"O olho vai perdendo o encanto. Como tudo o que adquirimos.

Tudo se incorpora ao todo, e é então que o encanto desfaz." (Mutarelli, 2002: 54)

No primeiro excerto, o olho de vidro cumpre função de objeto modal. A compra efetuada pelo dono da loja de penhores corresponde à conjunção com um poder-fazer; colocada em discurso de forma menos categórica do que de intensidade, pois o poder não é adquirido, mas ampliado. Em seguida, por conta do rompimento de relações com a bunda, o qual efetiva um estado de desesperança, o olho passa à função de anti-sujeito, na medida em que coloca o sujeito do ser em disjunção com o objeto de valor. Essa performance é figurativizada pelo "azar". A atribuição desse poder disjuntivo é transferida para novos atores, que correspondem aos sentimentos presentes no olho. No último trecho, as funções modais e actanciais dadas anteriormente são desfeitas por meio do desencantamento.

Trata-se de alguns dos momentos mais importantes do percurso de transformação da figura do olho, que, no nível mais estritamente discursivo, assume origens diversas como o pai do narrador ou David Bowie. Esses modos de ser limitam-se à interoceptividade, pois as transformações não ocorrem no âmbito exterior ao narrador-personagem. Por causa da sobremodalização patêmica, o sujeito cognitivo escolhe a figura do olho para construir novos sentidos a respeito da realidade. É um estado de encantamento, por meio do qual um elemento apenas pode sustentar todo o sentido do mundo. Todavia, quando o encantamento se perde, a figura volta ao estado cujos limites de significância são impostos, em grande parte, pelo todo da exteroceptividade, independentemente dos desejos do sujeito passional e cognitivo.

"O cheiro que aspiro vem do inferno.

O vulto é o cheiro também. 
Porra eu estou assustado.

É tudo culpa do cheiro do ralo. Amanhã mesmo vou mandar cimentar." (Mutarelli, 2002:

29)

"Esse cheiro tem história.

Foi o cheiro que me trouxe a bunda.

É um presente do inferno.

É minha perdição.” (Mutarelli, 2002: 65)

“O cheiro me dá poder." (Mutarelli, 2002: 67)

Seguindo a ordem dos excertos, a transformação operada com a figura do cheiro do ralo vai da disforia à euforia. Entre o primeiro e o último momento, é possível estabelecer uma oposição, na medida em que, da passagem de um a outro, o medo dá lugar à modalização do poder-fazer; dessa vez, categórica. Isso porque o medo é uma paixão cujo efeito pragmático é a não ação ou o não-poder-fazer.

No segundo trecho, o tratamento valorativo da figura em questão é complexo, já que o cheiro é eufórico e disfórico concomitantemente. Sua qualificação como "perdição" e sujeito do fazer no percurso que coloca o sujeito do ser em conjunção com o objeto de valor correspondente à bunda e "salvação" une os termos opostos da categoria semântica da foria - processo muito bem sintetizado pelo segmento "presente do inferno", porque, no contexto, as palavras que o compõem possuem conotação positiva e negativa, respectivamente.

As transformações são, outra vez, oriundas da interoceptividade. Ao cheiro do ralo, tão encantado quanto o olho, se atribui uma série de funções e valores, sem que, levando em consideração a isotopia realista da narrativa, haja transformações correspondentes. $\mathrm{Na}$ relação entre intero e exteroceptividade, o sujeito cognitivo dá prioridade à primeira, de modo a entender a segunda conforme outras lógicas. A palavra "culpa", presente também no exemplo anterior, indica o caráter actancial dado a figuras, cuja intervenção nas ações narradas é bem mais sutil para o narrador-personagem como sujeito pragmático do que como cognitivo e passional. 
"A bunda é e sempre foi, o desejo, a busca de tentar alcançar o inatingível. Esta bunda era, enquanto impossivel, enquanto alheia, o contra ponto do ralo. Mas o que eu realmente buscava não estava ali. Nem tampouco em outro lugar.

O que eu buscava, era só a busca.

Agora é preciso encontrar algo novo, de preferência uma bunda nova, para acreditar. Uma nova bunda que eu possa crer. Nessa bunda eu não creio mais." (Mutarelli, 2002: 134)

A bunda, como as figuras acima, sofre algumas transformações no decorrer do romance, e influencia aspetos importantes da narrativa. Na passagem selecionada, retomase o caráter de salvação, quando ela aparece declaradamente como "a busca de tentar alcançar o inatingível". Contudo, a palavra "busca" revela um dos momentos em que o narrador-personagem toma consciência de que os valores e sentidos dados a ela advêm de uma questão outra: a necessidade de busca, cuja razão de ser é passional.

No trecho, o narrador dá a entender que a figura da bunda é escolhida quase arbitrariamente. O elemento que discursivisa, para a percepção do sujeito cognitivo, o objeto de busca, com o qual se deseja entrar em conjunção, deve ser inalcançável, e a mudança desse estado acarreta a impossibilidade. Sendo assim, qualquer outro elemento que atendesse a essa condição poderia ocupar o seu lugar. Utilizando o verbo crer, a sobremodalização do sujeito cognitivo pelo passional, torna-se mais clara. Mesmo sabendo que a crença é mero artifício, na medida em que idealiza ou desiconiza, tornando encantado o objeto do mundo natural, há a necessidade de encontrar uma outra figura em que se possa acreditar, ou seja, atribuir poderes de encantamento. O percurso desenvolvido acima, do qual o narrador se dá conta, é justamente a passagem do crer ao não-crer, um processo que, nesse caso, pode ser chamado desencantamento.

A consciência repentina dessa transformação consiste na inversão do modo ser do narrador-personagem. O sujeito cognitivo, antes sobremodalizado, instaura um saber sobre o querer, racionalizando o sujeito patêmico. É desse modo que a cognição acerta, e transforma em tema um dos processos recorrentes da enunciação passional, a reorganização actancial e discursiva da realidade por meio da imaginação. Denis Bertrand, a partir das Cartas da Religiosa portuguesa, discute tal processo, o qual denomina " simulacro": 
“A projeção dos simulacros é a característica central da enunciação passional. Ela consiste em uma espécie de desdobramento imaginário do discurso. Nela o sujeito elabora objetos repentinamente dotados de qualidades sintáxicas inéditas [...]

$O$ distanciamento que assim se forma entre as duas figuras subjetivas (a epistolar e a passional) modifica o estatuto funcional da própria carta: sua sintaxe intersubjetiva é modificada pelo sujeito passional em seu beneficio exclusivo. Tudo se passa como se este, arranjando um espaço que lhe é próprio, com suas marcas e seus limites, empurrasse para os confins de seu discurso o sujeito epistolar e provocasse seu apagamento. O discurso de um ao outro se transforma em discurso para si mesmo, o que a mediação dos simulacros possibilita pela exploração dos valores dos quais eles são o suporte e sua atualização sintagmática de suas virtualidades”.

(Bertrand, 2004: 379 e 385)

No texto analisado por Bertrand, compõem-se duas figuras subjetivas, a epistolar e a passional, que são depreendidas, sobretudo, dos diferentes modos de tratamento do francês (tu e vous) que aparecem. Com o uso do vous, embreante do sujeito epistolar, o enunciador dirige-se, à maneira das cartas, a seu destinatário. O vous, embreante do sujeito passional, serve à construção de um simulacro no qual os percursos e valores são modulados conforme o querer. De modo que o caráter dialógico do gênero epistolar cede espaço ao monólogo.

Em $O$ Cheiro do Ralo, no que diz respeito ao simulacro, talvez não seja possível falar na composição de duas figuras. Na verdade, a figura do narrador, dividida nas funções de sujeito passional e cognitivo, constitui duas isotopias; respectivamente: a de realidade e a de imaginação. A de realidade é configurada pelo enredo simples do dono da loja de penhores, que termina assassinado por uma das clientes de quem abusa. A de imaginação erige-se por meio das transformações atribuídas a figuras como cheiro do ralo, olho de vidro, bunda, vulto, caixinha de música, anagrama, e assim por diante.

O que se depreende da relação entre as figuras da isotopia imaginária é um revestimento figurativo de viés religioso, no qual as figuras maiores, representando o bem e o mal, são o Paraíso e o Inferno; como já está apontado: salvação e perdição. Entretanto, do mesmo modo como ocorre em Jesus Kid, o uso de elementos temático-figurativos judaicocristãos exerce função meramente paródica, na medida em que as associações atribuem valores e sentidos descabidos, ou imaginários, a objetos do mundo natural. No que diz 
respeito à figura da bunda, essa característica é mais evidente, pois o encantamento que a eleva à condição de "salvação" se deve a um processo em que se reduz o ser humano à condição de objeto de desejo, contrariando todas as valorações do humano e as proscrições da sexualidade presentes na Bíblia.

Nada impede que a narrativa de um romance seja estabelecida por meio da imbricação entre real e imaginário. Todavia, $O$ Cheiro do ralo não se encontra uma simples junção dessas duas isotopias. $\mathrm{O}$ efeito de sentido é de incompetência veredictória. $\mathrm{O}$ narrador, como destinador absoluto da ação narrada, se propõe a referi-la sem distorções; objetivo que é impossibilitado pelos distúrbios psicológicos. De modo que, tal qual nas Cartas de uma Religiosa portuguesa, em que o epistolar dialógico, característico do gênero, cede espaço ao passional monológico, o relato do dono da loja de penhores, cujo foco é a exteroceptividade real, perde lugar para a interoceptividade imaginária, sob a modalização das paixões.

Tomando por base a análise que Rastier (1976) faz de "Salut" em "Sistemática das isotopias", é possível notar que a relação entre as isotopias do texto estudado se estabelece de modo particular. Ao contrário da conjunção isotópica da navegação, do brinde e da escritura, a relação entre realidade e imaginação pode ser considerada disjunta. Enquanto no poema como um todo, as três isotopias se realizam concomitantemente, com poucos semas que acionam apenas uma ou duas; no romance de Mutarelli, ocorre o inverso: considerando o percurso figurativo geral, ou se depreende a isotopia de realidade ou a de imaginação; a conjunção das duas é menos freqüente.

As formas de operar essa conjunção são inúmeras, vão desde a criação de episódios não tão convincentes, ao uso de clichês, e confirmações de dados supostamente imaginários por meio da opinião de outros personagens. Um exemplo de episódio duvidoso é o do anagrama, já referido, levando em consideração que a proposta de enigma e a menção de um sábio inexistente podem ser consideradas atitudes fora do comum para um cliente numa loja de penhores. O bilhete encontrado na boca do sapo, mesmo o próprio envio do animal, é outro caso. Isso porque se trata da macumba, que faz parte dos rituais de Umbanda e do Candomblé; e segundo a mitologia de tais religiões, o "Exu", figura depreendida do suposto anagrama do cliente da briga anterior ao recebimento da caixa com o sapo, é uma entidade maléfica, ligada, por vezes, ao Inferno, conforme o imaginário popular. 
O uso de clichês está presente em algumas cenas, que, por conta do exagero, tornam-se desconfiáveis, e muitas vezes, lembram o discurso televisivo. No trecho abaixo, o dono da loja de penhores e seu cliente, depois de dialogarem sobre a guerra, associam elementos (Hinos Nacional e paródia do da Bandeira) para compor uma encenação, em cujo fim representam uma batalha com auxílio de bonecos de chumbo:

"Relembramos, juntos, Monte Castelo,

Monte Della Torracia, Monte Gorgolesco

e Monte Belvedere. Cota 977. $1^{a}$ DIE.

O Terceiro batalhão,

Sexto Regimento da Infantaria

e Primeiro Esquadrão de Reconhecimento.

Viva os pracinhas! De pé, juntos gritamos!

De pé juntos. Associo.

Brasil! Brasil! Pátria Amada! Gritamos.

Cantamos. Salve, salve!

'Japonês tem quatro filhos...'

Ele em plena emoção me abraça.

$\cdots$

Eu o convenço de que os soldadinhos não devem ser vendidos.

Isso é uma coisa que não tem preço.

Pego um elástico, na gaveta de cima.

Enfileiro um grupo deles.

Vou para trás.

Faço a mira.

Atiro.

Faço, BUM, Com a boca, Dois são atingidos,

Ele pega o elástico e toma distância.

Agora é minha vez! Ele faz CATAPUMBA!" (Mutarelli, 2002: 45-46)

Após a encenação, o narrador-personagem leva seu companheiro para mostrá-lo aos clientes que esperam fora da sala. Apresenta-o como um amigo que lutou na guerra com seu pai - história inventada pelo narrador e aceita inexplicavelmente pelo o outro - ao que todos reagem admirados. O mesmo tipo de clichê está no sonho relatado à mulher que consegue grande soma de seu dinheiro ao se despir em sua loja. As duas incidências 
revelam a conjunção das isotopias de realidade e imaginação. No caso do sonho, sua lembrança posterior explicita o estilo televisivo por meio da intertextualidade com um comercial de pasta de dente e metáforas que associam o processo de pensamento ao de filmagem:

\footnotetext{
"Me imagino a correr por um labirinto. Suas paredes são cobertas de heras. Corro em câmera lenta. Do outro lado, é ela quem vem. Em câmera lenta, assim como eu. Nos abraçamos e giramos, giramos, giramos. Tudo em câmera lenta. Ai, meu pensamento enquadra meus dentes. E num zoom se aproxima. E meus dentes são brancos, no pensamento. E deles saem um brilhinho. E o brilho faz PLIM. Entra uma voz muito grave. A voz diz: KOLINOS. Hálito puro e refrescante. Volto após o reclame." (Mutarelli, 2002: 90)
}

Um dos elementos que possibilitam a distinção entre a isotopia de imaginação da de realidade é o ponto de vista dos outros personagens que não o principal, exposto por meio das falas. No que diz respeito à veredicção, são saberes mais persuasivos do que os do narrador; mesmo ele estando na posição de destinador último, já que a verdade dos outros é sempre conforme à sua. Levando em consideração a isotopia do real, erigida também a partir de outros aspectos, o que é dito e o modo como é dito são indicativos de veracidade. Por exemplo: a valoração de certas figuras (o cheiro do ralo, a bunda, etc.) pode ser entendida como excessiva, porque o restante dos atores que entram em contato com elas dá valores que lhe caberiam em grande parte dos contextos "realistas".

Há, todavia, momentos em que as declarações dos personagens, ao invés de tornar disjuntos real e imaginário, tornam ambas isotopias conjuntas, constituindo um novo problema de veredicção. Os vultos, que são vistos no local onde mora o dono da loja de penhores, parecem somente figuras oriundas de alucinações. Mas tal certeza é desestabilizada quando sua faxineira também assume os ver. A questão lógica de fidedignidade que se aplica nesse caso consiste nas seguintes possibilidades: os dois personagens têm distúrbios psicológicos; há de fato um vulto, do qual não se conhece a origem; a perturbação do narrador o leva a imaginar que sua funcionária declara ver também os vultos; ou a própria faxineira é uma invenção.

Situação análoga ocorre quando o médico do narrador-personagem afirma que ele não está amarelo, contrariando o julgamento de uma série de outros personagens, cuja 
conseqüência é sustentar o ethos progressivamente doentio do dono da loja de penhores. As possibilidades interpretativas para essa contradição são: o médico é incapaz de julgar e a aparência física é tão doentia quanto aparenta segundo as declarações freqüentes; os outros personagens são incapazes de julgar e o médico acerta quando percebe o paciente num estágio não tão avançado de doença; todas as declarações são mentirosas; a existência de todos esses personagens pode ser contestada.

Apesar de não predominarem, os momentos de conjunção têm papel fundamental nos efeitos de sentido. Trata-se de um modo de desestabilizar a veredicção mesmo no que diz respeito à constituição da isotopia correspondente a realidade. $\mathrm{O}$ motivo de ser dessa segunda desestabilização da competência cognitiva do narrador está diretamente relacionado ao caráter metalingüístico do texto analisado. Aspecto que se evidencia na grande quantidade de relações mais intertextuais do que interdiscursivas; sobretudo na lista de livros lidos pelo narrador, a qual destoa de seu caráter.

A constituição figurativa de um dono de loja de penhores insensível e explorador não condiz com sua vontade insaciável de leitura, muito menos com seu gosto, manifestado pela escolha de autores. Machado de Assis, Mário de Andrade, Paul Auster, Strindberg, compõem o ethos do gosto requintado e sensível, que destoa da brutalidade mostrada no decorrer do romance. O conhecimento e admiração de nomes da cultura, como Pollock, Orson Welles e Fritz Lang cumpre mesmo papel, associando o discurso à imagem do enunciador Lourenço Mutarelli, que, além de envolvido com Literatura, possui trabalhos relacionados a cinema e desenho.

Portanto, levando em consideração o sentido geral do texto, tem-se um narrador cujo referente é, em alguma medida, realista, sendo desestabilizado por seus distúrbios psicológicos. De modo que se constituem duas isotopias, correspondentes a realidade e imaginação. A desestabilização dessa relação disjunta tem efeito de sentido metalingüístico, que implica um novo estado disjunto; desta vez, entre narração e enunciação. Depreendem-se dois sujeitos do fazer discursivo: o narrador; e o enunciador, que, por não coincidir com o primeiro, consiste no ponto de vista do texto, já que as autoreferências explicitam o fato de que o discurso do romance é uma construção. Esse processo está na fixação do narrador-personagem em escrever um livro. Da mesma maneira 
que o exercício contínuo de suas leituras, ela condensa a desestabilização da veredicção e o dado metalingüístico, ou seja, torna narrador e enunciador disjuntos.

O que enseja a recorrência de ações que envolvem a figura do livro, sua valorização eufórica, é a interpretação de que ela possui vínculo com algo semelhante à salvação associada à bunda. As figuras que fazem parte da isotopia do real só não provocam a paixão da indiferença quando são percebidas em estado de encantamento. À grande maioria dos objetos oferecidos pelos clientes o valor que se atribui vem das necessidades de lucro do dono da loja de penhores, ativando saber e dever, em lugar do querer. A relação com as pessoas é dirigida conforme jogos de poder, por meio dos quais o dono da loja de penhores exerce função de manipulador, de modo que os personagens também estão no âmbito do disfórico, desprezível.

Os jogos não se limitam aos de poder. Aparecem freqüentemente no romance; às vezes, explicitamente, e outras, sem que o caráter lúdico da ação seja declarado. As cenas de compra e venda, que preenchem grande parte do espaço do livro, podem ser consideradas figurativizações de jogo, na medida em que consistem na valoração a objetos, diminuindo ou aumentando conforme eles e as reações do vendedor. Quando o dono da loja compra o produto por uma quantia abaixo da que ele atribui de fato, trata-se de uma vitória - o que acontece quase sempre.

No âmbito das relações sexuais, o mesmo se repete. O narrador propõe o jogo de compra e venda para mulheres atraentes se despirem, executarem favores sexuais e manterem relações. É insistindo nesse esquema, que ele afasta a "bunda" e perde grande soma de dinheiro para a cliente que, percebendo a lógica do jogo - em conjunção com um saber - executa um fazer: atribui valores, tomando seu lugar de destinador. O personagem principal tem consciência disso, e reflete sobre o ocorrido justamente num capítulo cujo nome é "O Jogo":

“Ai, ai, ai. Já fui ao banco, e as três caixas enchi. Com notas grandes, médias e pequenas. Sinto um calafrio. Será que ela estava mentindo para mim? Será que era tudo um jogo? Um jogo, só para pegar a minha grana?

O que será. O que será que aconteceu comigo. Estou perdendo o controle. Antes, era eu quem dava as cartas. Cartas marcadas. O jogo era meu." (Mutarelli, 2002: 106) 
Livros e jogos são importantes, porque o narrador euforiza elementos da imaginação, enquanto os objetos do mundo natural são disforizados sob a forma do desprezível. No momento em que o percurso de transformação de valores da bunda ocorre, as instâncias do real e do imaginário são figurativizadas por "coisas" e "inalcançável", respectivamente:

"A bunda é, e sempre foi, o desejo, a busca de tentar alcançar o inatingível." (Mutarelli, 2002: 134)

"E assim, mais uma coisa a bunda se torna.

Como tudo, como as coisas, que tranco na sala ao lado." (Mutarelli, 2002: 136)

O mesmo ocorre com o olho:

"O olho vai perdendo o encanto. Como tudo o que adquirimos.

Tudo se incorpora o todo, e é então que o encanto se desfaz." (Mutarelli, 2002: 54)

Ambos os percursos figurativizam o processo de desencantamento, que pode ser considerado a transformação da possibilidade na impossibilidade de se atribuir um significado do âmbito da imaginação a um objeto do mundo natural. $\mathrm{O}$ trecho seguinte é bem ilustrativo no que diz respeito à valorização eufórica do imaginário ("coisas que não estão ao alcance de nossas mãos") em oposição à diforização do real, por esse ser mais temático, mais generalizante:

"De todas as coisas que tive, as que mais me valeram, das que mais sinto falta, são as coisas que não se pode tocar. São as coisas que não estão ao alcance de nossas mãos”. (Mutarelli, 2002: 89)

Por meio do acionamento da isotopia do táctil, o narrador mostra-se conjunto a figuras ligadas à exteroceptividade, enquanto deseja entrar em conjunção com as relativas à interoceptividade. O encantamento é um mecanismo que possibilita a transformação da 
primeira na última. Entretanto, possui eficácia restrita, por conta de seu modo de operar virtual, identificado como mentiroso pelo próprio narrador (assim ocorre o desencantamento):

"Toda carga que depositei na bunda, infelizmente, quando me refiro à carga depositada, é uma figura meramente psicológica. Esta bunda, que agora abraço, era a minha salvação." (Mutarelli, 2002: 133)

“Agora não quero mais nada. O vazio se expande de mim... Pouco a pouco, em coisa me torno. Não sei se pego no sono, ou se é ele quem toca em mim. Desligando do mundo engrenagem. Onde todos se movem por mover." (Mutarelli, 2002:137)

A imaginação acionada pelos jogos e pela leitura é uma necessidade do narradorpersonagem. Diante de um mundo no qual as figuras são qualificadas como desprezíveis por conta de sua insignificância, o dono da loja de penhores executa um fazer virtual, na medida em que é somente psicológico, para destacar elementos e lhes atribuir propriedades excepcionais (encantamento). $\mathrm{O}$ estado de disforia com o real e euforia com o imaginário, advém, portanto, da categoria semântica totalidade x parcialidade, correspondente, no nível discursivo, a real e imaginário. O seguinte quadrado semiótico apresenta tais relações:

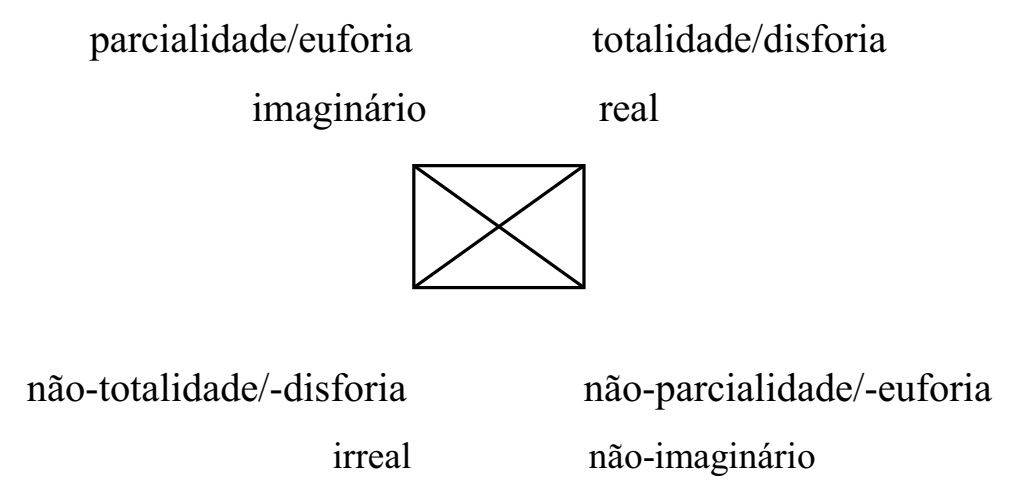

O sujeito do ser, em conjunção com o objeto de valor da totalidade, deseja entrar em conjunção com o da parcialidade. Sendo o mesmo ator do destinador manipulador e do 
sujeito do fazer, movido pelo querer, sem entrar em conjunção com o poder e o saber-fazer, realiza uma performance que ele mesmo, na função de destinador julgador, julga simulada ou mentirosa. Segundo sua maneira de interpretar o mundo natural, o único meio de executar essa performance efetivamente seria escrevendo um livro, o que ele é incapaz de fazer:

"Penso em escrever um livro só com frases que um dia eu grifei. Tornar meu, o que não era meu. Tornar meu o que adquiri. [...] Eu queria um dia escrever um livro. Eu não queria plantar uma árvore. Não queria um filho. Queria só um livro. Queria ler um livro que eu mesmo escrevesse." (Mutarelli, 2002: 124)

A vontade de criar um livro manifesta-se no que já está referido como incompetência do fazer poético: o modo de organização do texto submete-se e contraria as adequações de formas recorrentes do gênero romance. Propõem-se ligações desestabilizadas, como as cenas do anagrama e associações de enredo; tal qual a suspeita de que a ex-mulher do dono da loja de penhores é que teria mandado a cliente que assume o poder no jogo sexual, somente por conta da alusão ao vício no jogo do marido da última, e a menção da primeira a respeito de uma conhecida que sofria do mesmo problema conjugal:

"Quando percebi, ela perguntava o que eu achava daquilo. Eu falei que era assim mesmo. Então você acha certo um pai de família fazer uma coisa dessas? O quê? Gastar tudo no jogo. Claro que não." (Mutarelli, 2002: 12)

"E agora tudo se encaixa. Fazendo um sentido absurdo. É macumba, é vodu, é o diabo a quatro. É jeje. Tudo se enquadra. Tudo me volta à ex. Ela disse que eu não me livraria tão fácil. Ela bem me avisou. Ela falou da amiga, cujo marido, no jogo, tudo perdeu. Meu amor é pau mandado. Arapuca da ex." (Mutarelli, 2002: 106)

A paixão, o desejo de entrar em conjunção com o imaginário, que corresponde à parcialidade, no nível fundamental, sobremodaliza a razão e o fazer; de modo que a narração constrói um sentido romanesco para o real, que se mostra não efetivo. A seqüência "tudo se encaixa" e "fazendo um sentido absurdo" sintetizam o desejo de se 
configurar uma isotopia estrutural do romance, que interfere em seu caráter veredictório e composicional; em suma, no poder de persuasão.

Entretanto, todos esses problemas que interferem na competência do fazer discursivo dizem respeito à instância do narrador, com quem o enunciador estabelece relação disjuntiva. A incompetência do primeiro corresponde à competência do último, da mesma forma que o não-fazer, não escrever o livro, realiza o mesmo fazer do enunciador, por meio do recurso lingüístico do lítotes, em que se nega no enunciado e se afirma na enunciação:

"E aí ouço um novo BUM.

O Cheiro do Ralo.

Esse era o nome do livro que eu nunca escrevi." (Mutarelli, 2002: 141)

Depreendem-se dois percursos inversos. O do narrador, que detém um poder-fazer e um saber-fazer, na medida em que manipula seus clientes, e que, progressivamente, entra em disjunção com esse objeto modal, até ser manipulado pela mulher que entende as regras do jogo de sedução e morrer, em nome da vingança de uma cliente ultrajada. Levando em consideração os valores atribuídos às figuras, tem-se o dono da loja de penhores, que julga falso seu modo de operar a conjunção com o objeto de valor relativo a totalidade. $\mathrm{O}$ enunciador, pelo contrário, realiza a performance cujo objetivo é a escritura de $O$ Cheiro do Ralo, que, subentende-se, é verdadeira. Essa relação inversa pode ser depreendida de um diálogo, no qual o próprio narrador assume sua falsidade para um interlocutor que assim o define:

"Até sua cara é uma mentira.

Sei.

Essa cara que o senhor usa não é a sua.

Jura?

Essa é a cara do comercial.

É uma máscara que eu uso.

É, porque o senhor não tem cara. É máscara mesmo. Se tirar fica só um buraco.

To. Pegue o dinheiro, e vá embora.

O senhor tem a máscara da mentira. 
E você tem a cara da verdade.

O senhor é a mentira.

E você, a verdade." (Mutarelli, 2002: 124)

Tanto para o enunciador, como para o narrador, as figuras do mundo natural que não fazem parte do imaginário são diforizadas por corresponderem à totalidade do nível fundamental. Para ambos também, o caráter desprezível das figuras está constantemente ligado seu potencial de transformar-se em mercadoria; por esse motivo, a colocação da disforia em discurso se dá, geralmente, por meio do uso do verbo "ter" ou "possuir", em lugar do "ser". A mesma razão possibilita que certos livros, por causa da função meramente utilitária ou de venda, possam ser disforizados; como é o caso dos que se encontram no consultório que o narrador-personagem freqüenta:

"Quando levanto os olhos vejo o Dr.

O consultório é cheio de livros.

Mas esses livros não são como os meus.

Esses livros não tem histórias.

As gráficas não deviam fazer esse tipo de livro.

Esses livros não deveriam ser lidos.

Esses livros nos tiram a história.

Esses livros não deixam ser eu.

Esses livros só trazem receitas.

Receitas de um sabor amargo.

Esses livros de um fazem todos." (Mutarelli, 2002:72-73)

$\mathrm{Na}$ descriminação do sentido utilitário como elemento subversor da arte, a figura da televisão, predominantemente tediosa nos momentos em que a narrativa se passa na moradia do dono da loja de penhores, cumpre função importante. Do mesmo modo como se dá com os livros no trecho acima, filmes, atores e programas são distinguidos entre os que colocam em conjunção com o objeto de valor relacionado à totalidade ou parcialidade, conforme julgamento a respeito da realização da performance. Assim, podem ser 
entendidos como motivados os aspectos clichês, muitas vezes televisivos, que surgem na narração de um sujeito que está próximo ao utilitarismo.

Depois de manter relações sexuais com a mulher cuja bunda é fixação, como está mostrado anteriormente, essa figura perde o encanto que a associa à salvação e ao imaginário, e ela se torna um objeto qualquer, de modo semelhante às mercadorias guardadas na loja de penhores. Talvez por ser desfeita a única possibilidade de entrar em conjunção com o imaginário, pois não há competência para o livro ser redigido, em seguida, o narrador-personagem interpreta a si mesmo como parte do todo, disforiza-se, e morre. A morte marca o estado final do sujeito do ser no percurso: parcialidade $\rightarrow$ nãoparcialidade $\rightarrow$ totalidade.

Trata-se de um sacrifício; o que corresponde a determinado ponto de vista em relação à Literatura, principalmente levando em consideração o fato de que o assassinato, semelhantemente a um deus ex-machina, define drasticamente a separação entre narrador e enunciador: um deles representa o utilitarismo, a afirmação do mercadológico e a impossibilidade de imaginação e efetiva, e o outro que critica todos esses aspectos por meio de um romance. Por meio de tal construção figurativa e actancial, Lourenço Mutarelli estabelece uma poética cujos valores são a negação da realidade material (principalmente a ligada ao mercado) e os fins utilitários. Para isso, o autor deve suprimir - é a função do tema do sacrifício - essas características em si mesmo.

O resultado é a literatura não corrompida pela matéria e que serve como salvação diante do mundano. O artifício do lítotes reafirma o cunho religioso negado pela paródia; de modo que a imaginação literária se apresenta mais verdadeira do que as figuras do mundo natural, com a utilização de recursos metalingüísticos. Além da religiosidade, há também a função performativa da literatura, que realiza um fazer além do estético e do persuasivo, na medida em que defende seus valores no momento em que se efetiva. Tais concepções recuperam outras interdiscursivamente, das quais um bom exemplo sintético é a conhecida declaração de Mallarmé de que "tudo foi feito para terminar num belo livro." 


\section{JESUS KID E IRONIA}

O motivo de os capítulos desta dissertação não seguirem a ordem cronológica dos livros analisados - O Cheiro do Ralo, O Natimorto e Jesus Kid - se deve ao fato de que o primeiro e o segundo são muito mais próximos entre si no que diz respeito ao tema central do que se comparados ao romance que os intermedeia. No parágrafo inicial de Jesus Kid, é possível levantar vários pontos fundamentais em comum entre ele e o texto que inicia a produção literária de Lourenço Mutarelli:

"Não consigo respirar. Abro a boca buscando ar. Transpiro. Tremo. O lugar me oprime, estou parado na porta do restaurante. Licença, um homem atrás de mim diz. Dou passagem, ele entra. Meu coração bate desorientado. Acho que vou ter um enfarte, ou um derrame. Tomo um comprimido amarelo. Procuro me concentrar. Penso nos trinta mil. Penso nas minhas dívidas. Preciso entrar." (Mutarelli, 2004: 12)

A seqüência narrativa que se constitui pelas cinco primeiras frases indicam elementos essenciais do narrador, como sujeito cognitivo e passional. Em princípio, o campo figurativo faz parte da fisiologia; e sua construção sugere um estado doentio do personagem principal, que provavelmente sofre de alguma disfunção no corpo, sem revelação da causa. Logo depois, a frase que encerra o percurso mostra que os sintomas apresentados são psicossomáticos; ou seja, a descrição objetiva, ou exteroceptiva (apesar de ser interna, na medida em que se refere ao interior do corpo), tem função de reiterar a isotopia de um ethos passional.

Como é presente na ficção de Mutarelli, depreende-se do trecho a imagem de um personagem desequilibrado mentalmente. Esse desequilíbrio torna-se mais claro quando se descobre o contexto que provoca o medo, sintetizado pela declaração "o lugar me oprime". Trata-se de um simples encontro entre o escritor que narra e produtores de cinema no intuito de fecharem contrato para ele escrever um roteiro. Pode-se encarar o percurso que apresenta o desconforto psicológico para, em seguida, revelar a origem desproporcional como uma quebra na figuratividade. A reação psico-fisiológica é somente mostrada como exagero depois da construção figurativa que, levando em consideração a tradição literária 
ou até mesmo do cinema, indica o início de uma cena de aventura, na qual os riscos deveriam ser muito maiores do que os de um encontro de prestação de serviços.

Retomando a alusão cinematográfica, se afirma que a construção figurativa é semelhante às típicas cenas dos chamados "filmes de ação", em que um ambiente público, muitas vezes, um restaurante, serve de cenário a enfrentamentos, como lutas e trocas de tiro. Já que os distúrbios psíquicos ainda não são conhecidos, a constituição textual provoca a expectativa de que algo drástico está para acontecer. Por isso, ocorre a associação aos tipos de filme mencionados, que, a todo momento, recorrem a transformações como essa são passagens, na maioria das vezes, bruscas: do ritmo lento, sem ação, para o extremamente rápido. A expectativa é, porém, desfeita por meio da quebra de isotopia, cujo efeito é desestabilizar o percurso narrativo cinematográfico de filmes de ação na medida em que a apreensão do narrador decorre somente da sensibilização exagerada do ambiente que o cerca.

Como se pode notar, nesse romance, o distúrbio psicológico, figurativizado pelo pânico, tem seu imaginário bem próximo do cinematográfico. Um dos modos mais freqüentes de essa intertextualidade de gêneros ocorrer se dá nas intervenções de Jesus Kid, personagem criado pelo escritor, e que muitas vezes participa da ação. O que se passa após o trecho citado acima é um bom exemplo de tais aparições:

"Penso em Jesus. Evoco Jesus Kid. Jesus ajeita o chapéu de forma a esconder os olhos. Jesus Kid entra. Jesus Kid é frio. Caminha pelo suntuoso restaurante. Nada o intimida. Jesus Kid não tem medo de nada. Jesus caminha pelo restaurante. Não está tranqüilo porque sempre está alerta." (Mutarelli, 2004: 12)

A caracterização de Jesus Kid condiz com o típico herói de western; o que se dá na ênfase à falta de temor e ao gestual - ajeitar o chapéu, esconder os olhos, caminhar suntuosamente - típico desses personagens. Outro dado que aproxima o imaginário do romance ao de cinema no trecho selecionado é a existência de um alter-ego fantástico que participa da ação mais realista, por estar em conjunção com um poder-fazer. Há muitos filmes, sobretudo de heróis, que trabalham com esse jogo de atores, como Clark Kent e o Super-Homem. A referência, portanto, não se limita ao cinema, mas também aos quadrinhos, que, freqüentemente, serve de origem figurativa aos longas-metragens. 
Todavia, levando em consideração a escolha do personagem de western, pode-se afirmar que a alusão é mais forte em relação a eles do que às revistas.

O estilo do texto também contribui para a intertextualidade entre cinema e literatura. O constante uso do presente do indicativo, a predominância de diálogos intercalados com narrações que acionam os sentidos da visão e da audição, a referência a expressões que aludem ao fazer cinematográfico (como "ação" e "flash") aproximam Jesus Kid do gênero do roteiro. Abaixo se encontra um dos inúmeros exemplos onde se repete a palavra ação, em seguida, outro, onde aparece o termo fade:

\footnotetext{
"Toda homofobia que ontem fui obrigado a engolir explode na cara de Chet. Ação! Chet voa de costas até encontrar a parede. Vejo Chet aderindo a parede feito um escarro. Ação! Sua cabeça estala num baque tão surdo.” (Mutarelli, 2004: 122)
}
"Enfermeira Nurse dá um sorriso maroto e senta no meu colo. Me beija enquanto a tela escurece num fade." (Mutarelli, 2004:141)

Do mesmo modo como em $O$ Cheiro do Ralo, o desequilíbrio psicológico se relaciona à fixação. Em Jesus Kid, porém, não há o freqüentemente encantamento, causado, no romance anterior, sobretudo pelas figuras do ralo, bunda e olho. A fixação é semelhante à vontade de escrever um livro que colocaria o sujeito em conjunção com o objeto de valor relativo à alteridade. Dessa vez, porém, o que se instaura, em lugar de um querer, é um dever-fazer, imposto pelas dificuldades financeiras do narrador e pelos produtores que o contratam. Ou seja, nos dois romances, a escritura corresponde ao programa de base; num caso, um livro; noutro, um roteiro.

A diferença de atores que cumprem papel de manipulador implica formas diversas do ethos desequilibrado, que interferem no caráter veredictório do texto. Em $O$ Cheiro do Ralo, a vontade do narrador de escrever um romance coloca em prática e desestabiliza recursos literários tradicionais, criando (se for considerada a função do enunciador) um problema motivado de veredicção: o sujeito passional predomina sobre o cognitivo; assim também se conjugam imaginação e realidade.

No caso de Jesus Kid, o narrador tem maior consciência de quando o real apreendido pela percepção se transforma em imaginário; por esse motivo no trecho de 
início, para se livrar da paixão do pânico, concentra-se no futuro depois da entrega do roteiro: "Procuro me concentrar. Penso nos trinta mil. Penso nas minhas dívidas. Preciso entrar".

O sujeito passional, às vezes, predomina sobre o cognitivo, mas esse último é, muitas vezes, capaz de inverter a relação, substituindo cognitivamente a paixão da aflição pela da esperança. Trata-se de um percurso narrativo contrário ao que se dá com o dono da loja de penhores. Enquanto no âmbito figurativo de sua interoceptividade, o sujeito passional predomina e coloca ilusoriamente o sujeito do ser em conjunção com o objeto de valor; o narrador-personagem de Jesus Kid como sujeito passional adquire a função de antisujeito. Ciente da necessidade da conjunção com um saber-fazer, que corresponde à redação de um texto de gênero nunca praticado pelo escritor, o sujeito cognitivo vai de encontro ao passional. O modo como opera esse controle pode se dar mentalmente ou por meio do uso de remédios:

"Volto exausto para o quarto. Nem Pink, nem Nurse. O quarto fede à comida chinesa em decomposição avançada. A janela emperrada. Respiro o ar falso. Sinto o terror de um nove derrame e a falta de ar causada por uma enfisema pulmonar. Puxo um extrato e descubro ter avançado no limite. Nada de crédito. Só débito. Gargantas do caralho. [...] Mesmo sendo tarde faço a vinheta soar." (Mutarelli, 2004: 137)

“- Então, Eugênio o que você não está entendendo?

- Eu... Não é que eu não estou entendendo, eu só tenho uma dúvida.

- Vamos fazer assim, eu vou levar Melissa para casa e passo pelo escritório do Max e voltamos aqui. Os dois, eu e o Max. Aí conversaremos melhor. Enquanto é tempo.

Eles saem. Fábio pareceu realmente aborrecido. Evoco Jesus, mas ele não responde. Betabloqueadores. Sudorese. Ando de um lado para o outro. Começo a perder o controle. Sinto que vou ter um ataque epilético. Tudo se torna ameaçador.” (Mutarelli, 2004: 58)

Além do controle sobre o desequilíbrio psicológico, sua origem e figurativização o distinguem do modo como aparece no primeiro romance de Lourenço Mutarelli. O delírio provocado no dono da loja de penhores advém de elementos variados, transformando-os em objetos de valor e sujeitos do fazer, conforme associações dirigidas patemicamente; o que implica uma espécie de volubilidade de sensações. Diferentemente, a paixão que aciona o 
desequilíbrio do roteirista é somente a do pânico, e, quase sempre diante de um risco efetivo; nos dois trechos apresentados acima: o não cumprimento do contrato e a insatisfação dos produtores em relação a narrador-personagem - nos dois casos, o risco é de melhorar o estado crítico das condições financeiras.

Pode-se afirmar que os distúrbios do escritor são mais amenos do que os do dono da loja de penhores, já que o primeiro, além de poder controlá-los, não atribui valores e funções a figuras, geralmente, apenas as sobrevaloriza. Em alguns momentos, não é possível determinar até que ponto ocorre sobrevalorização. O pânico diante da sensação de não poder cumprir a tarefa delegada é um exemplo deles, afinal não é possível saber ao certo até que ponto é a gravidade dos problemas materiais do narrador.

Quanto à figurativização do desequilíbrio, as diferenças influenciam diretamente no fazer persuasivo. No primeiro romance, a inconsciência com relação às fragilidades da percepção resulta numa imbricação entre real e imaginário. Em Jesus Kid, a consciência é concomitante ao surgimento das perturbações figurativizadas como alterações na fisiologia; e não como delírio. Ou seja, as perturbações não alteram ou sobredeterminam passionalmente o sujeito cognitivo e seu fazer discursivo, o que implica em estabilidade veredictória.

Entretanto, há um recurso no que diz respeito à confiabilidade do narrador de modo similar ao que se sucede com o dono da loja de penhores. A vontade de redigir um livro faz que esse último transforme elementos da realidade lhes atribuindo um caráter literário. Eugênio, movido pelo dever-fazer do acordo com os produtores, também modifica sua cognição, nesse caso, seguindo padrões de roteiro. Repete-se, para tal finalidade, a desestabilização figurativa do realismo por meio do fantástico, com a diferença de que o acionamento dessa outra isotopia tem motivação lúdica e passional.

Além da motivação, outra diferença entre os dois textos reside no fato de que a relação entre isotopia realista e fantástica se transforma no decorrer do texto; de modo que é possível determinar seu percurso narrativo (o que não se dá em $O$ Cheiro do ralo). Os parágrafos que sucedem o de abertura do romance estabelecem uma disjunção entre elas, por meio da qual a primeira se mostra real, realista e exteroceptiva, enquanto a outra aparece como imaginária, fantástica e interoceptiva: 
“Penso em Jesus. Evoco Jesus Kid. Jesus ajeita o chapéu de forma a esconder os olhos. Jesus Kid entra. Jesus Kid é frio. Caminha pelo suntuoso restaurante. Nada o intimida. Jesus Kid não tem medo de nada. Jesus caminha pelo restaurante. Não está tranqüilo porque está sempre alerta. Todas as pessoas do restaurante são bonitas e saudáveis. Todos no recinto possuem pelo menos trinta e dois dentes. Brancos. Eu sou feio. Meus dentes são amarelos. Jesus Kid tem o rosto marcado e uma beleza agressiva. Procuro esconder meu desconforto. Jesus Kid nunca demonstra emoção.

$[\ldots]$

“Deixo que Jesus atue por mim. Jesus os saúda tocando a aba do chapéu com o indicador. Eles sorriem.

- Cara, que bom que você veio.

- Eu falei que ele viria.

Jesus puxa a cadeira e senta. Nada fala. Os dois tomam café. Um estica a mão quase emocionado.

$[\ldots]$

Apertamos as mãos. Eles continuam sorrindo. Me olham com estranheza e admiração, como se vissem um corcunda ou um anão. Um deles diz que me imaginava diferente, mais alto talvez “mais parecido com Jesus Kid”, diz o outro.” (Mutarelli, 2004: 12-13)

No início do trecho, a construção figurativa parece indicar uma narrativa do tipo fantástica, pois do que se lê se depreende uma cena de paródia religiosa, na qual, há a evocação de um personagem mítico híbrido de Jesus Cristo e um herói de western, que se concretiza efetivamente, como entidades em livros sagrados. Todavia, há elementos que, paulatinamente, invalidam essa interpretação.

A seqüência "Procuro esconder meu desconforto. Jesus nunca demonstra emoção." parece servir apenas de complemento aos paralelismos comparativos que opõem Jesus Kid a Eugênio, o narrador-personagem: destemido $\mathrm{x}$ temeroso, feio $\mathrm{x}$ belo, extrovertido $\mathrm{x}$ introvertido. Contudo, levando em consideração o que se narra a seguir, se aventa outro modo de entendê-la: Eugênio passa a agir conforme seu personagem agiria; desse modo, o esforço em esconder o desconforto seria resultado da tentativa de ser fiel à imitação ou vice-versa.

Esse outro sentido, que instaura ambigüidade na seqüência, torna-se mais forte quando se encontra a afirmação "deixo que Jesus atue por mim”. O personagem criado pelo narrador toma atitudes, as quais não dão certeza se ele está realmente em presença ou se 
apenas a imaginação o criou: saúda os produtores e senta-se. O verbo "apertamos" intensifica a ambigüidade por estar na primeira pessoa do plural, podendo corresponder ao cumprimento somente entre o escritor e os produtores ou incluindo também Jesus Kid.

No último parágrafo do trecho, uma terceira leitura é criada. O estranhamento dos produtores sugere a possibilidade de que nem Jesus Kid se concretiza efetivamente acompanhando o narrador-personagem, nem é apenas fruto de sua imaginação, mas que por um meio mágico este se transforma naquele. Logo essa hipótese é invalidada, quando um dos produtores revela que talvez a não semelhança com o herói seja o motivo da admiração.

A sobreposição de um terceiro sentido sobre a ambigüidade anterior e o fato de que ela adquire mais força por conta da construção figurativa é um dos indícios do efeito de ironia que predomina no romance como um todo. Trata-se de um curto jogo de enunciação, por meio do qual é acionada uma interpretação; outra que não instaura univocidade; em seguida, mais uma, que parece estabelecer univocidade (seja a do narrador ter se transformado de fato em Jesus Kid, seja de ele crer tanto nessa transformação que seu desequilíbrio psicológico tenha se tornado espantosamente perceptível); ao final, o ponto de vista dos outros personagens que invalida esse modo de entender a relação entre as figuras.

O jogo, que estabiliza e desestabiliza leituras, pode ser considerado um modo de instaurar distanciamento entre enunciatário e enunciado. Com a efetivação de isotopias válidas e inválidas conforme momento específico, na condição de manipulador, o enunciador estabelece relação instável com o enunciatário na medida em que coloca seu próprio discurso em questão. Segundo as possibilidades oriundas da combinação entre ser $\mathrm{x}$ parecer, o dito passa da condição de verdadeiro a mentiroso, um segredo (o narradorpersonagem se transforma em Jesus Kid) aparece, logo depois, torna-se mentira, e assim por diante.

Desse percurso, se pode depreender o caráter metalingüítico do texto, que instaura separação entre enunciador e narrador. O narrador participa da ação e a relata, cumprindo função de sujeito do fazer e do saber; concomitantemente, o enunciador, na condição de sujeito do fazer textual, estabilizando e desestabilizando possibilidades de leitura, indica o dado do discurso como construção lingüística - trata-se de um recurso semelhante à embreagem enunciativa, na medida em que a referência ao enunciado é também própria texto no qual a metalinguagem aparece. Considerando que narrador e enunciador consistem 
em funções diferentes, pode-se afirmar que, paralelamente à participação na ação e o nãosaber com relação ao futuro do primeiro, o saber e o fazer do segundo permitem a ele, ao resolver a questão veredictória revelando implicitamente o discurso como construto, propor um jogo ao enunciatário.

O jogo, que também é freqüente em $O$ Cheiro do Ralo, surge em Jesus Kid, de outra forma. Uma das diferenças diz respeito à importância desse elemento na constituição do texto. No romance anterior, sua contribuição corresponde a uma figura que instaura a transformação da disjunção para conjunção com o objeto de valor. No texto analisado neste capítulo, pode-se definir o jogo como um mecanismo de enunciação, cujo objetivo é explicitar a veredicção, de modo oposto ao referencialismo icônico da estética realista. Em síntese, num caso, os jogos são propostos pelo narrador e no outro, pelo enunciador. $\mathrm{O}$ segundo ponto que difere os dois romances diz respeito aos tipos de jogo. Enquanto nos jogos do dono da loja de penhores há sempre um vencedor e um derrotado; nas proposições do enunciador de Jesus Kid, ocorrem adivinhações, das quais o vencedor (o enunciatário que descobre ou o enunciador que engana) não se define, mas é uma resposta aberta que depende do contexto de leitura. Por conta disso, é possível dizer que, como no romance de estréia, é possível encontrar a função performativa da linguagem.

Os aspectos metalingüísticos e performativos não estão presentes somente nos parágrafos iniciais. De modo análogo a $O$ Cheiro do Ralo, a abertura da narrativa contém, mesmo que de forma irregular, elementos fundamentais do texto. Naquele, a paródia da forma romanesca tem importante função, já que o lítotes, acionado primeiramente por ela, estabelece a relação entre narrador, narração, enunciador, enunciação, que interferem no essencial do sentido. Neste, o percurso que aciona possibilidades de leitura, por meio do jogo proposto pelo enunciador, tem a mesma importância.

No mesmo capítulo ao qual pertence o excerto inicial analisado acima, o modo de ser da figura do personagem Jesus Kid começa, pouco a pouco, a ser definido. A seqüência abaixo ilustra essa definição:

\footnotetext{
“- Acompanha boillabaisse?

- Por que não?
} 
Responde Jesus Kid por mim. O garçom sai. Os dois continuam sorrindo para mim. Faço a gueixa de novo, cobrindo os dentes amarelos. Tento agir com naturalidade. Faz de contas que almoço nesse tipo de lugar todo dia.

$\cdots$

Jesus Kid quase não consegue segurar essa. Por pouco, por muito pouco ele não saca a arma e dispara. Trinta mil, penso por ele... Trinta mil, engula essa pelos trinta mil. Jesus dá uma cusparada.

$\cdots$

Estou zonzo. Não agüento mais esse papo furado. Preciso pedir uma advance... Jesus Kid pegou no sono. Por ora, sou eu que cuido dele." (Mutarelli, 2004: 13-20)

Em certo sentido, a narração é ambígua no que diz respeito à constituição figurativa de Jesus Kid. Como suas ações e as do narrador-personagem se complementam sem que haja contradição direta, é possível que o texto corresponda a estilos de confluência entre aspectos realistas e fantásticos, de modo semelhante aos livros de Kafka. Todavia, a ação de Jesus Kid responder "por" Eugênio e a metáfora instaurada em "cuido dele" podem ser considerados como indicativos de que a essência do personagem é meramente imaginária. O fato de que o desenrolar dos diálogos não exprime a constatação dos produtores sobre a presença efetiva do herói de western contribui para essa interpretação.

Adiante, no romance, há muitas passagens onde se configura o modo com que opera a cognição do narrador que vai ao encontro da possibilidade de que a existência de Jesus Kid não passa de constructo interoceptivo. Podem ser considerados como exemplos os seguintes trechos selecionados:

"Um dos Macaquinhos do Hotel bate na porta trazendo o baralho. Assino o recibo e o Macaquinho vai embora. Entrego o baralho para Jesus. Jesus abre o baralho, deita na cama, tira o chapéu e o atira próximo a seus pés. Depois começa a arremessar carta por carta tentando encestá-las, como fazem os caubóis, e os americanos do cinema, para demonstrar tédio.

Imagino a câmera acompanhando cada uma das cartas. Das mãos de Jesus até caírem dentro do chapéu. Tudo em câmera lenta. Ação refinada”. (Mutarelli, 2004: 34)

“Jesus sussurra coisas no ouvido da enfermeira Nurse, ela ri. Por mais que me esforce não consigo escutar o que os dois sussurram. Eu conheço Jesus Kid muito bem. Sei que logo ele 
estará abatendo. Enquanto conversam aproveito para por os pensamentos em ordem. Minha cabeça precisa de uma boa faxina. [...] O Halterofilista continua sentado à mesa como eu o deixei. Tinha até me esquecido de sua existência. Ele permanece assim, esquecido. Jesus Kid atira o chapéu sobre o abajur." (Mutarelli, 2004: 70)

Como no trecho inicial do restaurante, nos dois momentos selecionados a ação do herói de western e a do narrador-personagem se complementam como se ambos tivessem as mesmas propriedades. Contudo, nesses casos, há elementos cuja função é indicar que a existência daquele é criação imaginária deste. A estereotipia que torna a realidade vivida pelo escritor próxima à fantasia dos roteiros de cinema é um deles.

Jesus Kid, que é declaradamente um personagem criado por Eugênio (o que não impediria a atribuição de propriedades que o levassem à condição de real das outras figuras do romance) é também um patente estereótipo. Suas ações, complementares, não desestabilizam esse ethos tão marcado. "Arremessar cartas" e "atirar chapéus" podem ser considerados modos típicos de comportamento para um herói de western. No final do primeiro excerto, o narrador explicita o acionamento da imaginação, cujo efeito é continuar a mesma isotopia instaurada anteriormente.

No segundo trecho, outro indício do possível caráter imaginário de Jesus Kid é a presença do Halterofilista, ator que deveria estar presente no roteiro por ordem dos produtores, e que surge no discurso como se participasse realmente da narrativa. Enquanto o herói e a enfermeira Nurse estreitam suas relações, o narrador aproveita "para por os pensamentos em ordem". Na dinâmica entre os dois atores, é possível afirmar que se constituem como um elemento complexo, na medida em que, sob as características de Jesus Kid ou de Eugênio, cada um deles pode exercer a função de sujeito do fazer; a de sujeito do saber, porém, restringe-se ao narrador-personagem. De modo que a construção figurativa sugere que as ações são realizadas por Eugênio que, por conta de sua imaginação, distorce o real, atribuindo ao personagem criado por ele propriedades que não lhes correspondem. A motivação desse processo é passional - do que se pode depreender uma sobremodalização. Trata-se de um resultado do dever-fazer, a pressão causada pela necessidade de redigir o roteiro baseado na realidade vivida.

Todavia, há um capítulo que desestabiliza essa leitura. Seu título é um recurso metalingüístico cuja ficção é ressaltar o papel transformador que ele cumpre: "Certas coisas 
nunca mais voltam a ser como antes". Eugênio, desesperado porque não consegue prosseguir com a elaboração do roteiro, aceita conversar com um famoso dramaturgo, chamado Geraldo Antunes, por sugestão do recepcionista do hotel. O encontro termina no quarto, onde, aparentemente, os dois mantêm relações sexuais. Dessa situação, não é possível saber ao certo como, vem a resposta para os questionamentos que impossibilitam a finalização da escritura. Afirmando se inspirar no teatro de Ionesco, o narrador-personagem coloca em prática a solução a ser tomada:

"Por isso, agora que tenho o caminho só me resta escrever e escrever e escrever. E é isso que faço agora.

Não consigo respirar. Abro a boca buscando ar. Transpiro. Tremo. O lugar me oprime, estou parado na porta do restaurante." (Mutarelli, 2004: 126)

O narrador re-insere o início da estória, sugerindo que deixaria no roteiro os relatos escritos até aquele momento; ou seja, o romance sobre a escritura do roteiro seria o próprio roteiro, atendendo às exigências feitas pelos produtores de que o conteúdo deveria ser a dor da criação. Da técnica escolhida decorrem algumas questões insolúveis com relação ao pretérito e o futuro. Com respeito ao primeiro tempo verbal, não é possível determinar se o texto final é reprodução fidedigna do relato - escrita concomitantemente ao que é narrado ou recriação. No que concerne ao segundo, também há confusão entre concomitância e não concomitância, pois nenhum elemento textual garante que a ação narrada se passa enquanto é escrita, podendo ser futuro imaginário.

Assim, pode-se afirmar que ocorre debreagem enunciativa temporal, que não possibilita ao leitor decifrar se o que é dito pelo interlocutor corresponde a uma romantização do passado, relato do presente ou imaginação do futuro. Tal processo acarreta a criação de um discurso no qual não se pode confiar, já que, em se tratando de persuasão, cada um dos tempos referidos age de modo diferente. Presente, passado e futuro constituem uma linha crescente do menos ao mais persuasivo, no caso do discurso de Eugênio. Porque seu efeito de sentido talvez seja o de que a escolha do passado permita re-elaboração, a do presente, constatação imediata - por mais comprometida que seja pelo ponto de vista de um narrador desequilirbado - e a do futuro, evidentemente, não passe de realidade imaginária. 
No que diz respeito à pessoa, a enunciação é simples: enunciativa, por conta do uso constante da primeira pessoa do singular. Todavia, há algo como uma debreagem da imagem do interlocutor. Durante a ação, ocorrem mudanças fundamentais, as quais culminam na passagem do não-saber-fazer para o saber-fazer do sujeito narrativo. Quando o pretendente a roteirista encontra um modo de resolver seus dilemas, o trabalho anterior, que parecia ser inaproveitável, ganha sentido e as crises psicológicas não têm mais razão de ser.

A debreagem temporal confunde essas duas imagens, e a linha de persuasão “passado-presente-futuro" torna-se evidente ao lado desse problema. De fato, o enunciado e a imagem do enunciador acompanham as mudanças, na medida em que a voz indecisa e a história sem enredo definido caminham, em seguida ao capítulo-chave, à resolução. Mas essa última consiste em recontar os fatos; e assim, não há como saber se o que Eugênio enuncia está já transformado, recontado, ou se o modo ser (saber/não-saber) do narrador acompanha realmente essa transformação.

É possível solucionar tal questão ao ressaltar que Eugênio é um enunciador fictício, o que está marcado pela escolha do nome diferente de quem é o efetivo autor do romance: Lourenço Mutarelli, apesar de o outro ser declaradamete o autor. Como em $O$ Cheiro do Ralo, depreende-se novamente uma relação disjuntiva entre enunciador e narrador. Neste caso, porém, em vez do lítotes, é o efeito de ironia que determina essa separação, o que se depreende dos jogos enunciativos e do saber-fazer discursivo do enunciador contraposto ao não saber-fazer do narrador.

Essa relação entre os dois sujeitos pode ser encontrada logo nos primeiros parágrafos do romance: nos jogos enunciativos, que propõem e desestabilizam leituras, na falta de consciência do narrador a respeito dos efeitos de seus livros em seus leitores, e em referências explícitas a textos com os quais se estabelece intertextualidade - contrapostas a uma organização consciente desses sentido.

No que diz respeito aos jogos enunciativos, está apresentada acima a análise que depreende possibilidades, negadas e afirmadas, por meio do quadrado constituído pela categoria semântica ser $\mathrm{x}$ parecer, instaurando um percurso narrativo dependente da recepção do enunciatário. Além da imbricação de diferentes relações modais (saber/nãosaber) do sujeito que narra, a relação entre as isotopias de fantasia e realidade também se 
transforma conforme a narrativa progride. Como está visto neste capítulo, no início o valor de realidade de Jesus Kid é ambíguo, se comparado ao de Eugênio, para, em seguida, se mostrar estritamente imaginário. Portanto, nos momentos em que os dois entram em conflito, tudo se passa segundo imagina o narrador. O acionamento da figura de Jesus Kid nada mais do que um recurso psíquico utilizado por Eugênio para enfrentar situações de risco. De modo semelhante a $O$ Cheiro do Ralo, as ambigüidades entre real e imaginário ocorrem por conta da sobremodalização passional sobre o sujeito cognitivo; o pânico modifica a percepção.

Contudo, mesmo essa leitura, que se estabiliza por quase todo o texto, é, progressivamente, contrariada, sobretudo no capítulo final. Na contraposição entre real e imaginário, certos aspectos que fariam parte da primeira isotopia a tornam frágil. A estereotipia é um deles: os produtores são excessivamente caricatos, fazendo exigências totalmente descabidas (como a de que a história do roteiro deve se passar num hotel e de alguma forma incluir favelas em seu campo figurativo). Outro aspecto é o dado motivadamente inverossímil como: o evento de pin-ups e o de halloween, ocorridos no hotel; as mensagens de ajuda enviadas por um prisioneiro por meio de biscoitos chineses que acompanham a comida do roteirista; coincidências, como o personagem sem movimentos chamar-se Lourenço, e a hospedagem da ginasta da televisão, admirada pelo narrador, no mesmo hotel em que ele se encontra.

Se há aspectos que aproximam a isotopia do real à do imaginário, podem ser encontrados outros que contribuem para o movimento inverso (aproximação do imaginário ao real), reunidos no parágrafo que encerram o romance. Nesse momento, o Halterofilista e os Favelados, que não passam de exigências dos produtores, e que, portanto, só podem estar no âmbito da imaginação, tomam partido da ação. O chinês, autor das mensagens, de cujo confinamento não se conhece os motivos - nem se sabe onde está confinado - também se transforma em participante da isotopia, que, antes, se mostra real, em oposição à fantasiosa.

O principal dado figurativo que contribui para discernir essa oposição, o modo como se relacionam Eugênio e Jesus Kid, se modifica completamente ao final do romance, já que o herói de western, mera criação interoceptiva, torna-se efetivo ator da exteroceptividade: 
“A câmera revela o caubói. É Jesus Kid. Ele entra, confiante, pelo restaurante e revida os disparos. [...] Quando chega ao saguão tira a faca da bainha da bota e risca um grande jota sobre a madeira envernizada. Após deixar sua marca de praxe se dirige à saída. Roda a porta giratória. A luz da rua nos ofusca a visão. Vemos uma tela branca. Ouvimos o ronco do motor de uma moto. Aos poucos, em um fade-in surge uma reluzente Harley Davidson. Sobre ela uma radiante Pin-up.

Jesus Kid monta na garupa. Tira o chapéu enquanto grita um Yahoo! A moto entra em movimento. Jesus sai de quadro. Surge: The End." (Mutarelli, 2004: 173)

No trecho acima, além de Jesus Kid surgir como personagem efetivo, há uma série de recursos que aproximam o texto do gênero de roteiro. "Vemos uma tela branca", "ouvimos o ronco do motor" e "surge: The End" são alusões a esse gênero textual, na medida em que servem para indicar efeitos visuais típicos de cinema. Mais explícitos, nesse sentido, são a expressão "fade-in" e o segmento "a câmera revela". Portanto, o encerramento do livro dá continuidade à isotopia de que ele é o próprio roteiro, conectada no referido capítulo-chave.

Levando em consideração as transformações que são operadas no desenvolvimento da narração, talvez a mais plausível das hipóteses no que diz respeito ao saber do narrador seja a de que, até o capítulo-chave, não há conjunção com o saber-fazer. O que significa que apenas, em seguida a ele, culminando na solução apresentada no fim, se congregam real e imaginário, segundo o ponto de vista do narrador-personagem. O motivo está no fato de que a não coerência com a distinção entre as isotopia cognitivas se acentua após a conjunção com o saber, figurativizada pela assunção da estética do absurdo.

A dificuldade de certeza a esse respeito é resultado da construção do romance, que, como está mostrado acima, possui, desde o início, elementos que excedem, mais discretamente, o que se pode chamar de "padrão de normalidade". Esse recurso, porém, não é do narrador-personagem, mas sim do enunciador, e sua função é instaurar a ironia. $\mathrm{O}$ mesmo se dá com a "vingança", que aparece algumas vezes em Jesus Kid, e pode ter duas interpretações, conforme se levar em conta diferentes sujeitos do fazer:

Uma fúria medonha e disforme. Se eu ousasse libertar essa ira, então vocês saberiam o que de fato é ação." (Mutarelli, 2004: 103) 
"Tenho três dias e isso me bastará para distrair os Gargantas. Vou transformar minha fúria que se transmudou em medo em histórias de acalentar Gargantas. Histórias não tão profundas quanto as próprias gargantas, mas histórias que entretenham e divirtam comedores de pipocas em salas de projeção. Vou dar forma e movimento às palavras e elas se converterão em ação, sangue e sexo. Engordarei minha conta bancária e saldarei minhas dívidas. Deixarei este maldito hotel e serei convidado a voltar. E quando voltar será um feliz reencontro. E me pagarão em dobro para que eu escreva histórias que se convertam em película. Farei espetáculos espetaculares que encherão os seus cus de dinheiro e os fará sorrir. Eu sou o senhor do verbo e o artesão das palavras." (Mutarelli, 2004:109)

O dever-fazer decorrente da manipulação dos Gargantas, por conta da necessidade de se livrar de dívidas, instaura a paixão do medo no narrador, que se transforma em ira, dando origem à vingança, conforme o esquema canônico de restauração de perda. O modo que ele encontra para se vingar é a elaboração de um roteiro condizente com os preceitos impostos, cujo objetivo é fazer do longa-metragem uma mercadoria vendável.

Essa solução, em termos actanciais, parece consistir simplesmente em realizar o programa de base, depois da conjunção com o saber (uso da estética do absurdo); realização essa efetivada pelo programa de base correspondente às relações sexuais com o famoso diretor de teatro. Contudo, as relações passionais têm função mais importante no que diz respeito a essas transformações. Os bloqueios de criação, dos quais padece o roteirista, não se devem apenas à não-conjunção com o saber, mas também com o querer. Em meio à narrativa, o narrador declara ter perdido espaço na editora para outro escritor, porque o conteúdo dos livros desse último é mais comercial. Isso quer dizer que, no campo figurativo, os impedimentos editoriais e de escritura do roteiro fazem parte da mesma instância. Eugênio disforiza elementos que tornem arte mercadoria, fato que o aproxima do dono da loja de penhores de $O$ Cheiro do Ralo.

A conformação com essa condição do roteiro e a decorrente aceitação das exigências dos produtores podem ser consideradas uma re-configuração nos modos de sentir. O contato com Geraldo Antunes, além do conhecimento de Ionesco, serve para que o narrador-personagem euforize a disforia; a vingança é tratar o público e os contratantes como eles merecem ser tratados, em nível baixo: "Histórias não tão profundas quanto as próprias gargantas, mas histórias que entretenham e divirtam comedores de pipocas em salas de projeção". 
Contudo, o imaginário absurdo, inverossímil, e superficial também está presente nos romances que Eugênio valoriza como se eles atendessem a uma verdade que não está presente no roteiro e nos livros de seu concorrente de editora. A própria criação de um personagem que une mitologia cristã e de faroeste, sem intenção de causar efeito de ironia, constitui a imagem de um escritor que não conhece efetivamente os alcances de sua obra. Trata-se de um dos meios utilizados (além dos jogos de enunciação e a intertextualidade) para separar enunciador e narrador, a diferença do saber, que resulta em maior competência do primeiro, e menor, do último, em relação ao fazer discursivo. A ironia constante do romance como um todo advém desse paralelismo.

Do modo como é discursivisada a conjunção com o saber-fazer, que possibilita a escritura do roteiro, pode-se depreender que a ação e o discurso do narrador-personagem, mesmo sendo críticos aos clichês e exageros, eles mesmos se tornam clichês e exagerados. No trecho abaixo, Eugênio descobre a forma de executar sua vingança, resolvendo expor, junto com ela, todo sofrimento causado pela manipulação:

"Essa é a resposta. Essa é a única possibilidade de inserir todos os ingredientes que me foram encomendados. Essa é a única forma. Devo me expor e revelar os meus mais secretos sentimentos demonstrando minha visão crítica e o doloroso processo criativo que venho sofrendo. Devo revelar a minha prostituição da alma, e agora também do corpo. Devo manifestar o ridículo da intenção dos Gargantas e o meu ridículo em aceitar por necessitar do dinheiro. Ninguém deverá ser poupado. Ou seja, Ionesco me diz para fazer o que intui no início quando ironicamente escrevi 'Querido Diário' e segui relatando os detalhes de meu dia-dia."

(Mutarelli, 2004: 125)

Ocorre, porém, que a chamada "prostituição" referida tragicamente pelo narrador sobretudo no que diz respeito ao corpo - carrega um aspecto cômico desconhecido por ele. A mesma comicidade está no personagem e construção de seus livros, que ele considera de tal modo sérios que não podem ser vistos como banalidade. Dado momento, a voz do enunciador aparece sob a fala de um dos contratantes, definindo ele mesmo a consciência de Eugênio como efeito de ironia e apontando sua inconsciência no que diz respeito a isso:

“- É muito bom. Essa coisa de mostrar o ridículo do western de ironizá-lo dentro de sua fórmula é ótimo. 
Jesus Kid quase não consegue segurar essa." (Mutarelli, 2004: 15)

O evidente efeito de ironia do western cristão não é percebido pelo narradorpersonagem; e por isso, seu alter-ego, Jesus Kid "não consegue segurar essa". No entanto, a colocação em discurso da constatação dessa possibilidade, por meio do ponto de vista interlocutores, pode ser considerada uma forma de o enunciador negar o conteúdo geral do que está sendo narrador. Outra passagem, na qual se encontram as impressões de enfermeira Nurse, mulher com quem tem um caso, sobre seu romance, tem função semelhante. E nesse momento, Eugênio afirma que todos, sem exceção, são ridículos:

“- Você não poupa ninguém, nos expõe ao ridículo.

- Nós somos isso... somos todos ridículos. Não há exceção.” (Mutarelli,2004:140)

A ironia também aparece na forma de caricatura dos personagens e no enredo absurdo, mesmo ele sendo explicitamente assumido como tal; há dois modos irônicos, o de Eugênio e o de Mutarelli. Isso porque, se forem levadas em conta as transformações narrativas, o absurdo surge antes da assunção da estética. Ressalta-se que tal adiantamento pode ser interpretado como uma paródia do que seria a aplicação do conceito aristotélico de necessidade. Elementos aparentemente desconexos do enredo e sem importância para o seu desenvolvimento, como o sumiço de tampinhas de banheira e a ginasta da tv, chamada Cadela em Pink, mostram-se fundamentais. Há exemplos, como os pedidos de socorro vindos em biscoito chineses e o encontro de pin-ups, em que a paródia da necessidade é ainda mais intensa, pois, no que concerne a eles, a mesma desconexão e desimportância é resolvida ao final - que, como já se sabe, é absurdo. Isso porque, do discurso do romance, pode-se depreender uma discussão a respeito de possibilidades estéticas, por meio da qual são contrapostas a do absurdo e a aristotélica.

Eugênio tem de inserir no roteiro personagens femininas em quantidade suficiente para que haja atrizes suscetíveis à sedução do diretor e produtor; um halterofilista, para dar lugar ao filho do dono do hotel onde se hospeda; salgados, porque talvez haja interesse de uma indústria em investir no filme; e a favela, que retoma o caráter contraditório da composição; pois o espaço do longa-metragem é o hotel, sendo necessário aproximar dois elementos de campos figurativos distantes. 
Os problemas de elaboração - contradições, associações de figuras pertencentes a campos figurativos distantes - decorrem da iminente quebra de princípios estéticos de Eugênio, as exigências feitas ao conteúdo do texto obrigam-no a se aproximar de um indevido absurdo, como ele próprio identifica. O entendimento de que esse aspecto é impertinente tem sua razão de ser, porque vai de encontro a um fundamento específico, a verossimilhança:

"Para mim, cabem os livros. Livros cheios de páginas, cheios de frases que contenham sentido. Mesmo que o argumento seja nefasto, composto por personagens inverossímeis, halterofilistas escritores filhos de donos de hotéis." (Mutarelli, 2004: 103)

O que está em jogo, e pode ser depreendido pelo discurso do narrador-personagem, é uma discussão a respeito de estética. Diferentemente de outras vertentes, como o Surrealismo, o Grotesco, linhas Kantianas ou Hegelianas, ele filia-se à tradição aristotélica dos preceitos de concisão e necessidade:

\footnotetext{
"Tanto na representação dos caracteres como no entrecho das ações, importa procurar sempre a verossimilhança e a necessidade; por isso, as palavras e os atos de uma personagem de certo caráter devem justificar-se por sua verossimilhança e necessidade, tal como nos mitos os sucessos de ação para ação.

$\dot{E}$, pois, evidente que também os desenlaces devem resultar da própria estrutura do mito, e não do deus ex-machina, como acontece na Medeia ou naquela parte da Ilíada em que se trata do regresso das naves." (Aristoteles, 1998:124)
}

O que torna difícil escrever o roteiro, pois o mercado, cujos representantes são os atores produtor e diretor, valoriza o que seria acessório, mesmo que isso acarrete o uso do deus ex-machina. Todavia, a interdiscursividade e a intertextualidade que acionam o embate de duas posturas estéticas, correspondentes às de Aristóteles e Ionesco, podem ser consideradas efetivas somente no que diz respeito ao discurso do narrador.

Se for levada em conta a disjunção desse último com o enunciador, é possível depreender efeito de ironia. Novamente sua causa advém da relativa inconsciência do narrador, que se depreende de um não-saber fazer discursivo. A discussão sobre estética, fundamentada em posições teóricas diferentes, não é explícita em sua narração, porém, a 
forma como ela é desenvolvida, por meio de um percurso temático muito bem construído, depreende-se um segundo sujeito do fazer discursivo, o enunciador. O impasse aristotélico resolvido com uma solução calcada no teatro do absurdo, principalmente considerando o fato de que o narrador a desconhece até o capítulo-chave, revela um ponto de vista mais complexo do que o seu. Outro dado importante é a ordem da valoração das influências para a elaboração do roteiro:

"Geraldo Antunes me deu a solução do problema. 'Nem Fink, nem Fante. A resposta que procuro está em Ionesco. ” (Mutarelli, 2004:124)

Segundo o ponto de vista do narrador, apesar de a "resposta estar em Ionesco", sua importância como referência é a mesma que a de Barton Fink e John Fante. Tal valoração pode ser considerada frágil, na medida em que cada uma das referências tem papel completamente diferente na história da cultura. Barton Fink é apenas um filme recente que não efetiva grandes revoluções no cinema; John Fante é um escritor cuja consagração não possui as mesmas proporções do teatro de Ionesco. A atribuição à influência do último a função de solucionar os problemas de elaboração, contudo, indica a presença de outro saber-fazer discursivo, estabelecendo uma crítica ao repertório dos escritores envolvidos com a indústria cultural.

Se Eugênio vinga-se por meio da manipulação do enredo, e inserção de elementos extremamente absurdos, os quais rompem com a figuratividade ideal e sugerem ausência de percursos temáticos consistentes (arte sem conteúdo), repete o mesmo processo executado pelo enunciador Lourenço Mutarelli. A vingança do narrador - excetuando momentos pontuais - é acionada a partir do capítulo em que ele assume a inspiração em Ionesco. A de Mutarelli se dá no romance como um todo. Esse paralelismo entre enunciador e interlocutor também pode ser encontrado nos nomes dados aos personagens. Da mesma forma que "Gargantas", "Cadela em Pink", "Boneco de cera", são criados segundo alguma qualidade significativa de seus referentes, "Eugênio" é claro jogo de palavras entre "eu" e "gênio", e tudo leva a crer que a razão de o homem sem movimentos chamar-se "Lourenço" é gerar efeito cômico, resultado da homonímia com o autor. 
Assim se resolve a problemática no que diz respeito às debreagens de tempo e fusão de imagens do interlocutor. Esse último narra a partir do presente, o qual se completa com um futuro imaginário. Entretanto, o efeito de sentido de seu discurso é o de narração concomitante a uma ação factual, enquanto o do outro corresponde a um mundo imaginário. São duas estéticas diferentes: a do narrador-personagem, que inicia realista e se transforma em absurdo; e a do enunciador, na qual o absurdo predomina, deslegitimando o discurso de seu personagem.

Retomando a separação das isotopias correspondentes a real e imaginário, pode-se dizer que elas, segundo o ponto de vista do narrador, estão disjuntas até o capítulo-chave, para depois entrarem em conjunção. Essa mudança também opera uma transformação no caráter veredictório do texto, pois na primeira parte as figuras são resultantes da cognição, enquanto na segunda, somente ligadas à construção textual. No campo da enunciação, o dado de constructo é presente em todo romance, o que pode ser depreendido pelo fato de que a história é sobre um roteirista que escreve um roteiro, o qual é, na realidade, o próprio romance lido pelo enunciatário.

A intertextualidade também contribui para o estado disjunto entre enunciador e narrador. No princípio de Jesus Kid, dentre as recomendações dos produtores, algumas delas são a leitura dos livros de John Fante e do filme Barton Fink, desconhecido por Eugênio. Contudo, referências aos dois parecem estar presentes no discurso do texto. $\mathrm{O}$ enredo de Barton Fink, por exemplo, também é sobre um roteirista contratado para elaborar o próprio filme do qual faz parte. "Chet", nome que Eugênio atribui insistentemente ao recepcionista do hotel, Arlindo, é o mesmo que leva um recepcionista no longa-metragem.

No que diz respeito à construção do texto, por conta do acionamento de modos canônicos de constituições temático-figurativas, Jesus Kid se aproxima de $O$ Cheiro do Ralo, na medida em que isotopias são acionadas por relações intertextuais com o gênero romance. Da mesma forma que a cena inicial do anagrama provoca a espera de determinado tipo de desenvolvimento cujo prosseguimento tradicional é frustrado, a abertura no restaurante que aciona a expectativa de um livro calcado em filmes de ação não se cumpre completamente. São dois casos de paródia.

No primeiro deles, o gênero de romance aventuresco, no qual também se encontram proposições de enigmas, se estabelece em razão das perturbações psicológicas do narrador, 
que valoriza o imaginário em detrimento do real - a percepção, o sujeito cognitivo, sobremodalizado pelo passional, confunde as duas isotopias, criando um problema de veredicção. Contudo, há a presença do enunciador, disjunto do narrador-personagem, evidenciada por alguns elementos que indicam a realidade efeiva: ele não é nada além de um dono de loja de penhores, desequilibrado, cuja banalidade da vida corresponde à totalidade, objeto de valor conjunto e disfórico.

Essa relação entre enunciador e narrador se constitui por meio do lítotes, e manifesta o caráter de construto lingüístico do texto, sobretudo por conta de $O$ Cheiro do Ralo ser um querer-fazer e não um fazer; o livro que o personagem nunca escreveu. $\mathrm{O}$ resultado do lítotes é que, a despeito da disjunção cognitiva entre os dois sujeitos do fazer discursivo, as valorações são conjuntas, de modo que a literatura como salvação e a crítica do mundo que se repete coincidem nos dois discursos. Levando em consideração que a morte é necessária à feitura do livro, pode ser encontrado ainda, no discurso do enunciador, o tema da arte como sacrifício.

No caso de Jesus Kid, o acionamento da isotopia de um romance inspirado em filmes de ação é desestabilizado, mas, diferentemente de $O$ Cheiro do Ralo, ocorre no fim mais forte continuidade, mesmo que paródica, da proposta inicial. As exigências dos produtores configuram um encaminhamento no qual a dificuldade de conjunção temáticofigurativa de duas isotopias se mostra na própria elaboração do texto. No começo desse, encontra-se a isotopia do filme de ação, em seguida, a de conflito psicológico (os dilemas da escritura), e adiante, um encerramento que torna as duas conjuntas por meio de uma solução absurda (deus ex-machina).

Dentre outros aspectos, a inconsciência de Eugênio, que redige um roteiro com as mesmas características de seus livros de western, como se, por vingança, utilizasse elementos presentes somente nos romances que acha defeituosos, distanciam-no do enunciador. Novamente a totalidade, figurativizada pelas fórmulas editoriais e truques comerciais de cinema, é disforizada; enquanto a totalidade, correspondente ao texto original, as aventuras de Jesus Kid, se valorizam, segundo o ponto de vista de Eugênio.

Ocorre que, para a elaboração da escrita, inexplicavelmente, o reincidente sacrifício consiste na desconsideração da heterossexualidade do narrador-personagem, para manter relações com o diretor de teatro Geraldo Antunes. Em vez da morte de um comerciante que 
faz parte do campo figurativo da totalidade, a fim de que o discurso do enunciador se estabeleça como a negação de todos os elementos que ela compreende, a noite sacrificial de Eugênio possui caráter irônico, de modo que o discurso do enunciador está em relação disjuntiva com o sujeito cognitivo e o passional do narrador.

Assim, pode-se inferir que há uma transformação no discurso do narrador se for levado em conta o percurso temporal de um romance a outro. $\mathrm{O}$ modo de entender a literatura como sacrifício e salvação, dado de parcialidade diante da totalidade constante, é reacionado, mas criticado sob o efeito da ironia. Em lugar de se discutir sobre a abrangência das figuras da totalidade, ela é encontrada estritamente no âmbito da indústria cultural - em específico no meio editorial e cinematográfico. Menos esperançoso e idealista, no que diz respeito à arte, o discurso de Jesus Kid limita-se a criticar o nível das obras de arte e às dificuldades materiais pelas quais o artista passa. 


\section{O NATIMORTO: RELAÇÃO DE CONCORDÂNCIA ENTRE ENUNCIADO E ENUNCIAÇÃO}

Uma das diferenças entre O Natimorto: um musical silencioso e os romances estudados nos capítulos anteriores está no número de personagens, e na importância do personagem-narrador em relação aos outros. Ao contrário de O Cheiro do Ralo e Jesus Kid, em que há bem mais do que um indivíduo participando da ação narrativa, a história do segundo livro de Lourenço Mutarelli se passa quase completamente entre dois atores: $\mathrm{O}$ Agente e A Voz. Os fatos concomitantes à narração concernem, quase todos, à relação dos dois; e os elementos do passado contribuem para seu andamento.

Um agente artístico aposta no talento de uma cantora cuja voz é tão pura que não pode ser ouvida. A esposa, enciumada, revolta-se com a atenção voltada à moça, já que não consegue escutá-la. Por conta de uma briga, o marido e sua cliente vão para um hotel, onde, sob proposta dele, se hospedam por tempo indeterminado. No tempo de hospedagem, alguns desentendimentos e a teoria de que as advertências de cigarro funcionam como tarô provocam uma série de conflitos.

No que diz respeito a esse foco, o diálogo é mais predominante neste texto do que nos outros - na maioria das vezes, com as falas inseridas por meio do discurso direto. Maior iconicidade decorre de tal característica, na medida em que o efeito de sentido criado é o de que os fatos se apresentam do modo como ocorrem sem mediação de um ponto de vista; conseqüentemente, a percepção do enunciador torna-se, nesse sentido, próxima à infalibilidade, nos moldes da estética realista.

O recurso que desestabiliza a iconização, ligado ao senso comum sobre o possível e o impossível, assemelha-se, por isso, aos dos outros romances, caso forem levados em conta alguns elementos "fora do normal" presentes no enredo. O principal deles, ao qual o subtítulo do romance ("um musical silencioso") se refere, é a inaudibilidade da voz da cantora. Também contribuem para esse efeito de sentido aspectos mais sutis - a proposta e a aceitação de enclausuramento, e os tomates atirados na cantora de modo a confirmar a previsão do Agente são exemplos.

Como nos textos anteriores, são encontradas novamente a falta de referência clara com relação a tempo, lugar e pessoa, e a construção de personagens cuja constituição figurativa se assemelha a tipos abstratos, como os presentes em fábulas. O sujeito moral do 
narrador, divido entre categorias, tais quais bem x mal e puro x "poluído", utiliza estados fóricos para configurar os atores que fazem parte de seu discurso. Sua esposa, que o trai, o Maestro, amante de sua esposa, estão, sobretudo, ligados ao mal e ao poluído; da mesma forma que a Voz é pura e imaculada - em estado tão ideal (oposto à figuratividade icônica) que possui modo de ser semelhante aos das personagens inocentes de contos de fadas.

Essas desestabilizações, porém, produzem efeitos diferentes dos surtidos por $O$ Cheiro do Ralo e Jesus Kid. Não se pode afirmar que haja um problema de veredicção, por conta da desconfiança causada pelo ponto de vista instável do narrador-personagem. No caso de $O$ Natimorto, o percurso temático-figurativo é próximo ao do realismo fantástico. Seu desenrolar causa apenas estranhamento, diferentemente do que se dá com os jogos enunciativos, paródias, e o uso de clichês de Jesus Kid.

O que significa que, os distúrbios psicológicos, apesar de aparentes, não interferem na percepção do narrador. Levando em consideração que não se utilizam recursos de enunciação, como os de ironia e lítotes nos moldes dos romances já estudados, também não se pode dizer que as funções de enunciador e narrador sejam disjuntas. Ou seja, diferentemente do que acontece com os outros textos, o distanciamento entre o narradorpersonagem e o enunciador Lourenço Mutarelli se efetiva de modo menos categórico.

Para se determinar a relação entre esses dois sujeitos faz-se necessária uma breve tipologia das possíveis relações entre eles.

Tomando por base o estado utilizado para definir tais relações (de disjunção) nos capítulos anteriores, pode-se deduzir outras três possibilidades decorrentes do quadrado semiótico constituído por meio da categoria semântica conjunção x disjunção entre narrador e enunciador:

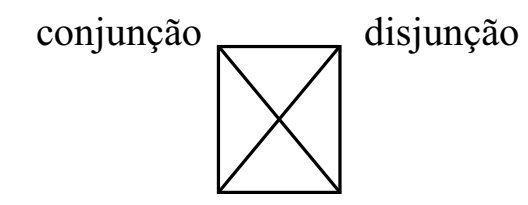

não-disjunção não-conjunção 
A lógica da tipologia, ao menos no caso de Mutarelli, não se pauta pela constituição figurativa, o que significaria: o narrador possui correspondência actorial com enunciador, a exemplo de certas confissões ou memórias assinadas com o nome do próprio autor. O problema em questão diz respeito aos juízos de valor a respeito dos temas tratados no texto. Com o uso do lítotes, em $O$ Cheiro do Ralo, o dono da loja de penhores, apesar de alguns conflitos internos, valoriza elementos disforizados pelo enunciador, e quando morre, figurativiza a necessidade de disjunção completa com o objeto de valor para a existência da literatura, que corresponde aos elementos euforizados por Lourenço Mutarelli. Em Jesus Kid, o efeito de ironia permite a assunção de clichês, soluções estéticas frágeis e até mesmo a re-utilização de temas e figuras do primeiro romance, segundo o ponto de vista do enunciador, a fim de criticá-los. Assim, se operam as relações disjuntivas.

Tendo em vista essas considerações, o estado conjunto seria aquele por meio do qual os juízos de ambos os sujeitos, enunciador e narrador, confluíssem. Uma forma de narrativa que parece se adequar a tal condição é a de heróis, cuja ação possuí caráter exemplar. Por conta de tornar clara a correspondência entre pontos de vista de narrador e enunciador é que talvez sejam elas, em sua maioria, escritas em terceira pessoa, de modo que a instância discursiva do narrador seleciona declaradamente os aspectos louváveis e censuráveis do personagem exemplar.

Em se tratando das possibilidades restantes, não-conjunção e não-disjunção entre narrador e enunciador, o uso da primeira pessoa esclarece mais facilmente esses processos constitutivos. Utilizando tal forma, o narrador pode ter seu ponto de vista colocado em questão e, participando das transformações ocorridas ao longo da narrativa, seu juízo está sujeito à crítica, sobretudo, se se levar em conta que, sob essa mesma função, há possibilidade de o sujeito cognitivo, o passional e o do fazer entrarem em contradição.

Não é pertinente a este trabalho o estudo detalhado e de esgotamento dessas possibilidades, contudo, é preciso estabelecer alguns parâmetros para que se entenda melhor de que maneira se colocam os valores encontrados em $O$ Natimorto. Parece que um dos modos de problematizar a relação entre os juízos de valor de narrador e enunciador é, de forma semelhante às inevitáveis intertextualidades com a tradição literária, o diálogo 
com a tradição de valores e os valores atuais de determinada sociedade, ou como denomina Bertrand: "destinador coletivo".

Os juízos se configuram por meio de uma relação dialógica, da mesma forma que os estilos literários e, em última instância, o discurso, conforme indicam as pesquisas de Maingueneau a respeito de interdiscursividade, podendo ela ser polêmica ou contratual. No que tange aos preceitos de certo e errado, que representam estados eufóricos e disfóricos, apesar de variações numerosas e intensas, há certas construções temático-figurativas cujo estado patêmico é tão freqüente que adquire uma condição quase canônica, em determinado contexto histórico-cultural.

Diante dessa realidade semiótica, que envolve a moral, os discursos, sejam eles literários ou não, assumem inevitavelmente uma posição. De modo que, além das relações contratuais e polêmicas com discursos mais específicos, tem-se a concordância ou não com o dito senso comum. A eficácia da veredicção depende, para além do constructo literário, do diálogo com o saber do "destinador coletivo"; pois, além da tradição da arte, que propõe formas aceitáveis, esse processo aciona saberes a respeito do mundo natural. Para o funcionamento da iconicidade realista, por exemplo, é necessário consenso no que diz respeito a causa e conseqüência, leis científicas, questões de probabilidade, fatos históricos, dados inúmeros sobre a sociedade depreendidos da experiências do dia-dia, e assim por diante.

Tais noções podem ser incluídas, com poucas ou muitas mudanças, num texto. Há certos movimentos, como, por exemplo, o Surrealismo, que se propõem a colocar seu discurso em polêmica com a constituição figurativa cujo senso comum estabelece ser universal - nesse caso, para se colocar em relação contratual com o discurso da psicanálise; e, portanto, também o destinador coletivo segundo a perspectiva temática. Assim funcionam a estética do absurdo, o Dadaísmo e outras correntes. De modo que, se a constituição figurativa de um texto absurdo obedecer a recorrências do senso comum pode, dependendo de sua realização, contrariar as coerções de estilo, criando um problema de veredicção.

Da mesma forma como os elementos cognitivos, o campo moral, que corresponde semioticamente a estados patêmicos, por conta de sua ligação com os valores atribuídos por um destinador, também é submetido ao senso-comum, o qual representa algo como o 
destinador "mais coletivo", de determinado contexto. Mesmo em grande escala, como pensando na Cultural Ocidental contemporânea, é possível depreender alguns princípios gerais ligados a valorações mais concretas, tais como preservação da vida humana, tratamento especial à criança e direito individual.

Quando um discurso vai de encontro a preceitos gerais, muito provavelmente está constituindo uma nova valoração. Entretanto, no âmbito literário, há ainda a possibilidade de a relação polêmica configurar um modo de tornar o enunciador disjunto do ponto de vista do personagem ou do narrador. Não é preciso que esse último censure explicitamente uma ação, essa última, unida a outras, pode criar um ethos, cuja isotopia moral é marcadamente censurável pelo destinador universal. O mesmo ocorre com o narrador, que, a despeito de não se declarar disfórico, pode se encontrar nessa condição por meio do conjunto de ações narradas ou do fazer persuasivo. Para tal tarefa a ironia é um recurso bastante utilizado, já que o exagero ou a seleção de atitudes que constroem um ethos censurável, quase caricato, efetiva-se como negação do enunciado. Em Dom Casmurro, o discurso de Bentinho contra Capitu torna-se auto-acusativo por meio desse mecanismo.

Há, porém, textos em que o narrador não está nem estado conjunto nem disjunto com o enunciador. Para colaborar com esse efeito de sentido, seu ethos é construído em relação contratual e polêmica com o destinador coletivo, sem que haja elementos textuais que configurem a proposta de um novo sistema moral do enunciador. Tal parece ser o caso do narrador de $O$ Natimorto, já que alguns fatos, como a traição da mulher, e a paixão idealizada, provocam a conjunção moral com o destinador universal, e outros, como a necessidade de enclausuramento e a fixação pelas advertências do cigarro, colocam ambos em estado de não-conjunção. No final do romance, a indicação do assassinato da cantora, cujo sentido advém de desequilíbrio psicológico, torna a relação disjunta; de forma que é possível depreender que as relações entre narrador e destinador coletivo, que interferem na relação entre o primeiro e o enunciador, também podem varia conforme a narrativa se desenvolve.

Retomando os estados disjuntos entre enunciador e narrador de $O$ Cheiro do ralo e Jesus Kid, é possível afirmar que, em $O$ Natimorto, surge um modo particular de enunciação, no qual a relação entre enunciador e narrador não é disjunta. Decorrem desse novo modo aspectos importantes no que diz respeito à construção literária. O principal 
deles concerne ao fato de que não há uso de paródia e não aparecem elementos metalingüísticos relevantes, no que diz respeito à produção de arte. Isso quer dizer que a discussão sobre literatura, tema fundamental nos textos analisados anteriormente, não aparce novamente. As únicas referências ao recurso metalingüístico com funções semelhantes ao que se encontra nos outros romances são as alusões ao fato de que o narrador-personagem conta histórias que admiram sua parceira de quarto:

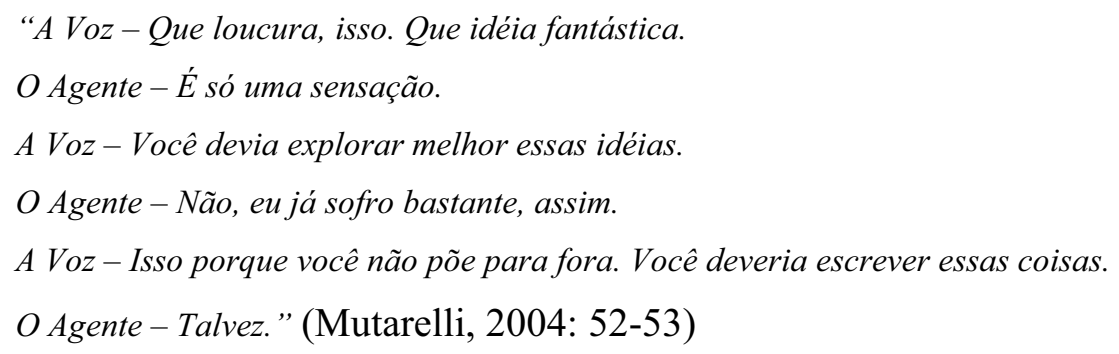

Apesar de não haver disjunção entre narrador e enunciador, não criando problemas no que tange à percepção, o desequilíbrio psicológico, presente no restante da obra de Mutarelli, é importante em O Natimorto. Isso porque os distúrbios modificam concepções, distorcem em alguma medida a lógica que rege os acontecimentos, mas não alteram dados físicos recebidos pela percepção. O Agente não tem alucinações, nem imagina que passa por situações as quais não ocorrem na realidade. Por isso, não há um problema veredictório como os encontrados nos outros romances: o efeito de sentido do texto é o de que os fatos narrados acontecem tal qual são referidos pelo narrador. $\mathrm{O}$ elemento problematizado é o modo de interpretar essa realidade - as implicações temáticas dos percursos figurativos que aparece explicitamente separado dela. (Ocorrem também acessos semelhantes a convulsões, mas que também não prejudicam os órgãos dos cinco sentidos no que concerne ao entendimento da realidade, pois o narrador separa nitidamente os momentos de sanidade e de perturbação.)

O enredo, narrado no presente, concomitante à narração, é bastante simples, constituindo-se apenas dos conflitos gerados pela relação afetiva recém-iniciada entre $\mathrm{O}$ Agente e A Voz. O que dá complexidade temático-figurativa à ação são as formas como o narrador-personagem recebe os acontecimentos, que decorrem de um modo específico de interpretar. Seu processo é determinado pela associação entre uma segunda isotopia e o 
contexto no qual se encontra. Há duas fontes básicas para acionar o processo associativo: o suposto novo tarô presente nas advertências de cigarro e episódios do passado - a esses últimos, freqüentemente, serve de apoio uma fundamentação teórica que aparece explicitamente no texto por meio de intertextualidade, sobretudo, com os filósofos alemães Friedrich Nietzsche e Arthur Schopenhauer.

No que diz respeito às advertências de cigarro, o processo imaginário de construção figurativa mais importante para o romance, a associação se dá por duas vezes. A primeira delas é a concepção do novo tarô, que parte de associações principalmente do plano de conteúdo visual das cartas e das embalagens. O trecho abaixo, no qual a figura de precaução contra enfarto é aproximada da que se encontra na carta do Diabo, serve como exemplo para esse método:

\footnotetext{
"O Agente - Na lâmina de número quinze, nós vemos duas criaturas, uma de cada lado, e, ao centro, num pedestal, está o Diabo.

O Agente - Agora, repare nessa foto, o que vemos?

A Voz - Vemos um médico e seu assistente, um de cada lado. No meio, um homem recebe uma máscara de oxigênio do assistente, enquanto o médico parece tentar ressuscitá-lo com uma massagem cardiaca." (Mutarelli, 2004: 53)
}

A segunda associação decorre da interpretação do conteúdo temático da figura original devidamente adaptado para o que seria uma nova ordem do tarô. Ambas associações são extremamente arbitrárias, o que pode ser depreendido do fato de que nos dois casos podem ter seu sentido alterado por causa de acontecimentos ou desejos que sugerem sua inadequação. Após uma discussão ensejada justamente pela interpretação de que a carta retirada pela Voz é o Diabo, o narrador-personagem se retrata, definindo-a como a do Enamorado, somente porque, na imagem, se encontra "a mão do médico sobre o peito do enfermo" (Mutarelli, 2004:69). Do mesmo modo como se dá com a correção ou redefinição de qual é a figura presente nas advertências, ainda é possível encontrar transformações de sentido, mesmo depois de definida a figura, por conta de motivações patêmicas. É o caso, por exemplo, da Grande Sacerdotisa que, num primeiro momento corresponde a: 
"É uma carta muito boa. É a sabedoria, o julgamento correto, o conhecimento sereno.

Discernimento." (Mutarelli, 2004: 71)

E em seguida, reaparece de outra forma, praticamente oposta à definição anterior, motivada pelo conflito causado no momento em que a nudez da Voz constrange o Agente:

\author{
"Eu não falei \\ que a Grande Sacerdotisa \\ também representa \\ emoções ocultas. \\ Incapacidade \\ de partilhar. \\ Tendência \\ para evitar \\ sentimentos. \\ E que, invertida, \\ pode ainda representar \\ falta de compreensão. \\ Ignorância.
}

Egoísmo." (Mutarelli, 2004: 77)

Há, portanto, dois planos, o das advertências de cigarro, que correspondem a figuras da imaginação, e o da realidade, do qual fazem parte cantora, esposa, maestro, hotel, etc. O modo de interpretar os elementos que são transmitidos pela percepção combina ambos, mas sempre deixando claro ao enunciatário a constituição de cada um, diferentemente do que ocorre em $O$ Cheiro do Ralo, por exemplo, onde não se sabe até que ponto são imaginários ou reais episódios como os da proposição do anagrama.

A mesma relação se estabelece com acontecimentos anteriores dos quais o narrador-personagem depreende um significado que interfere em suas ações concomitantes à enunciação. Os principais deles são a queda no poço, o conflito com um cachorro, a construção e destruição de um castelo de areia por um menino (em princípio quase todos são revelados como se fossem história a respeito de outras pessoas que não o Agente). Para que seja entendida de maneira mais detalhada a associação entre a realidade presente e a interpretação do passado é necessário que se retome cada um dos episódios. 
Quando criança, o narrador-personagem freqüenta a casa de uma avó em cujo quintal se encontra um poço. A fim de impedir acidentes, um de seus tios declara que no fundo do poço há um monstro. Por descuido, o sobrinho acaba caindo, e, observando o reflexo de sua imagem na água, conclui que ele e todos os outros seres humanos são os monstros: "Ele é como nós. Todos somos monstros", "Quando avistei o monstro e o reconheci, de medo, projetei sua imagem nos outros" (Mutarelli, 2004: 33). Também na infância, por volta dos dez anos de idade, o narrador-personagem é mordido por um cão, do qual se vinga, dez anos depois, espancando-o até despedaçar sua cabeça. O terceiro episódio, que consiste no testemunho de um garoto que constrói um castelo perfeito para depois o destruir, não possui referências claras à época em que se dá.

$\mathrm{O}$ que une esses percursos figurativos são os temas que acionam, segundo a interpretação do Agente. O monstro, o cão e o fazedor de castelos, que representam a destruição, são, primeiramente, atribuídos à instância da exteroceptividade; dando substrato a uma concepção negativista e amedontrada do mundo, na medida em que os elementos externos representam um risco. Por essa razão, é feita a proposta à Voz para que ela e seu agenciador permaneçam no hotel, para se protegerem da realidade externa. O quarto, que só pode ser considerado como uma metáfora da interoceptividade, é encarado literalmente desse modo.

Entretanto, por conta da ira provocada pela relação entre a Voz e o Maestro, as características destrutivas são encaradas como presentes na interoceptividade - de modo análogo ao que se dá no episódio do poço, no qual o monstro é outro, e depois, si mesmo; no do cão, em que a vingança projeta características violentas do cachorro na vítima; e em todos eles, se for considerado que as histórias são narradas, primeiramente, como se ocorressem com outra pessoa, e não com o narrador-personagem.

O elemento que possibilita essa transformação pode ser encontrado na referência a uma conhecida frase de Nietzsche:

"Quem combate monstruosidades deve cuidar para que não se torne um monstro. E se você olhar longamente para um abismo, o abismo também olha dentro de você." (Nietzsche, 2000: 79) 
Nesse aforisma, estabelecendo intertextualidade com a tradição romântica, o filósofo coloca em discurso as figuras do monstro, associada ao grotesco, de modo consagrado por Victor Hugo, e do sublime (que também aciona a paixão do medo), estudada por Kant na Crítica da Faculdade do Juízo. Segundo a discussão presente nele, pode-se inferir que o autor de Além do Bem e do Mal apresenta a possibilidade de as paixões da admiração e do horror, que concretizam graus intensos de euforia e disforia de modo geral, estimularem a transformação do sujeito patêmico no objeto que provoca essas paixões.

Os episódios do poço e do cão constroem-se dialogando com essa possibilidade. Em ambos os casos, o temor do monstro cede lugar à transformação nele mesmo: o reflexo na água e o ataque covarde e vingativo. No que se refere ao abismo, a queda possui relação figurativa evidente, na medida em que ela é provocada pela admiração curiosa e infantil pela profundidade. A associação das duas isotopias, oriundas da experiência pessoal e da leitura de filosofia, com o necessário modo arbitrário de interpretar, servem de motivação para que o narrador personagem execute o assassinato da Voz, cuja traição (assim como a da mulher) era prevista por conta de um conceito também nietzschiano: "o eterno retorno".

No trecho abaixo, se encontra o modo como se opera a associação entre a isotopia da filosofia e a dos episódios de infância:

\footnotetext{
"Quando a tábua

cedeu,

pela primeira vez

mergulhei no abismo.

A água fria

no fundo

gelou meu corpo.

Meu pequeno corpo.

E tornou frio

também o que sou.

Quando avistei o monstro

e o reconheci,

de medo,

projetei sua imagem

nos outros.
} 


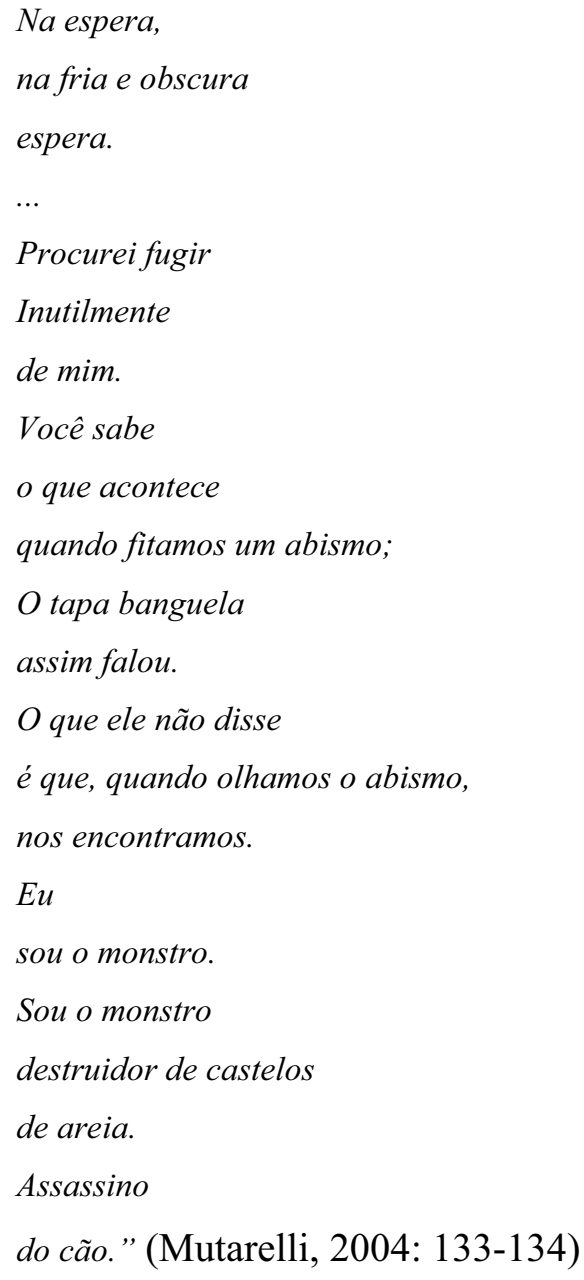

Os episódios de infância, incluindo o do castelo, e as referências textuais servem de motivação racional para a realização de uma performance cujo sentido é, na verdade, passional. De forma análoga ao assassinato do cão, a resolução de matar a cantora consiste em transformar medo em ódio - a mesma forma de defesa passional que aparece diversas vezes em Jesus Kid, principalmente na execução do roteiro, para a qual o medo de não conseguir executar a tarefa se modifica em vingança por meio da ironia.

Trata-se, portanto, de uma sobremodalização da paixão pela razão, o que distorce, diferentemente do que se dá nos outros romances de Mutarelli, não a percepção como um todo, mas o modo de interpretar do narrador-personagem. Tal mudança acarreta em outra: a desestabilização veredictória ocorre, a despeito de ser de maneira diversa dos textos estudados nos capítulos anteriores. Se nos romances metalingüísticos, de forma motivada, 
são principalmente as construções figurativas que não convencem, o problema veredictório de $O$ Natimorto está nas relações estabelecidas entre temas.

Há uma semelhança com $O$ Cheiro do Ralo, no que diz respeito à valorização das figuras materiais, que são disforizadas. O dono da loja de penhores, por conta de seu dinheiro, pode adquirir a maioria dos objetos pelos quais sente passageira atração, porém, na medida em que quase tudo lhe é acessível, adquire valor negativo, fazendo parte da totalidade, segundo a categoria totalidade $\mathrm{x}$ parcialidade, depreendida do nível fundamental. Tal concepção do mundo, próxima a grande parte dos consagrados discursos religiosos, estabelece intertextualidade contratual com a mitologia judaico-cristã e, por isso, o inferno aparece constantemente no texto, de modo a representar os valores negativos que, em última instância, estão ligados aos bens materiais. O narrador-personagem teme o inferno, porque, a despeito dos conflitos, só consegue agir em nome de desejos ligados à totalidade, enquanto a parcialidade, ligada ao mundo das idéias, e concretiza por meio da escritura do romance que não pode ser escrito; ou seja, na instância da enunciação.

Em O Natimorto, seja por meio da paixão do medo, que disforiza o mundo como um todo, generalizando seu caráter destrutivo, ou do ódio, que internaliza essa característica, o âmbito da matéria também é valorizado de modo negativo em oposição ao à esfera do ideal. $\mathrm{O}$ fascínio causado pela cantora reside justamente no fato de que sua voz é tão pura que não se concretiza, não pode ser ouvida pela maioria das pessoas. De modo que a interdiscursividade com grande parte dos discursos religioso prevalece, sem que haja entretanto uma correspondência direta com a mitologia judaico-cristã - apesar de referências ao inferno - por conta do diálogo explícito com o ocultismo ligado à crença nos entes do tarô.

Assim como ocorre em alguma medida com as concepções bíblicas em $O$ Cheiro do ralo, e evidentemente, com o cristianismo, em Jesus Kid, a mitologia surge de modo paródico, sobretudo porque a teoria do novo tarô das advertências de cigarro é um absurdo, já que assim parece ao interlocutor principal, A Voz, também ao destinador coletivo, e não contraria tal expectativa de maneira nenhuma - o que poderia ser feito com um acerto irrefutável das supostas cartas a respeito do futuro.

Para dar continuidade à comparação entre $O$ Natimorto e $O$ Cheiro do ralo, ressalta-se a questão do eu, que aparece em ambos. O ralo, negativizado pelo narrador, a 
um tempo possui caráter de alteridade, na condição de anti-sujeito conforme a passionalização que atribui funções variadas a diversos elementos do mundo natural por meio da imaginação, e a outro, é definido como "eu verdadeiro". Bastante significativa, nesse sentido, é a transformação operada no que tange à associação do ralo com outras figuras. Num primeiro momento, ele é comparado a portal; e num segundo, por meio do mito de Narciso, é comparado a um espelho, quando o dono da loja de penhores "admira sua própria imagem" ao olhar para ele.

Apesar de se diferirem em alguns pontos, ralo e poço se assemelham pela rotundidade, profundidade e falta de luz - é importante ressaltar que abaixo de ambos há conteúdo líquido, que pode servir justamente para reflexão de imagens. Nos dois textos, as duas figuras exercem função de mediação do outro, para dar lugar ao mesmo, o que, nas instâncias fórica e discursiva, representa a transformação do destrutivo disfórico altero em idêntico, a despeito de essa categoria não estar necessariamente presente no nível fundamental.

A questão da identidade também pode ser encontrada em Jesus Kid, todavia, sua constituição figurativa e suas conseqüências temáticas fazem-no se distanciar da configuração que lhe é dada nos romances antecessores. Nesse caso, a crise do eu se dá entre Eugênio e Jesus Kid, cujo resultado é um problema mais actancial do que temático. A troca de papéis entre criador e personagem consiste num jogo isotópico que alterna incompetência e competência para colocar em destaque o dado de labor do texto que, num patamar mais abstrato, coloca em pauta o tema da literaridade, por meio do acionamento da função metalingüística.

Apesar de contribuir à apresentação do texto como constructo, e, por esse motivo, se encontrar no título do livro que o narrador personagem "não consegue escrever", o ralo não se limita à questão metalingüística. Assim como o poço, ele serve como figura da reflexão, que permite ao sujeito cognitivo perceber que os aspectos disforizados pertencentes à exteroceptividade também fazer parte de si - trata-se de uma discussão existencial que retoma as filosofia de Nietzsche, na medida em que ela transfere para o indivíduo as responsabilidades morais.

No que tange ainda à questão da identidade e dos aspectos destrutivos, do modo como aparece no "musical silencioso", o próprio ato de fumar cumpre papel importante. 
Inúmeras são as aparições em que ele surge como adversidade (inserida, freqüentemente, por uma oração subordinada concessiva) para que a ação continue, sem que os personagens principais abandonem o vício. É possível verificar tais construções nos dois trechos abaixo:

\author{
"Mesmo advertidos e que \\ 'Fumar causa mau hálito, \\ perda dos dentes \\ e câncer de boca", \\ fumamos". (Mutarelli, 2004: 32) \\ "Mesmo ciente de que 'Nicotina é droga e causa dependência", acendo um novo cigarro"
}

(Mutarelli, 2004: 27)

O aspecto destrutivo, portanto, também está no ato de fumar continuado deliberadamente pelo Agente e a Voz. A inserção da adversidade pelo narrador indica sua consciência em relação ao fato de que, mesmo de forma sutil, ocorre sanção ao processo disforizado, sob o regime da autodestruição. Operando dessa maneira, ambos os personagens participam, inconscientemente, da função de anti-sujeito. Assim como se dá com a internalização da figura do monstro e a vingança contra o cão adiante, atribuí-se a função de sujeito do fazer ao próprio narrador, projetando características externas à interoceptividade.

Em determinado momento, se expõe claramente essa transposição, que efetiva uma re-configuração de sujeitos e atores, por meio da palavra câncer, cujo significado explicitamente metafórico fortalece a isotopia ligada à atitude destrutiva nos seus outros empregos aparentemente denotativos. Para colaborar com tal efeito de sentido, a história do menino que constrói castelos para, depois, os destruir, reaparece, de modo a uni-la a câncer, atribuindo à humanidade, sem exceção, o papel de destruidor:

\footnotetext{
"Somos como o menino

que constrói castelos

de areia.

Aguardamos

a materialização
} 
para podermos destruir

tudo o que construímos a nossa volta.

Essa é nossa natureza:

somos destruidores.

Somos o câncer

do mundo. (Mutarelli, 2004: 83)

Um ponto que aproxima os três romances é o sacrifício. Em $O$ Cheiro do ralo, como uma forma de redenção, ele surge no momento em que o narrador-personagem, ator representativo dos elementos disforizados que se ligam à identidade, morre, para, assim, se realizar a performance da escritura do livro não escrito em sua vida e que, na instância da enunciação, coloca o enunciador em conjunção com o objeto de valor que concretiza a alteridade. Também em Jesus Kid sua função é a de ensejar a produção de texto, mas o tema da literatura como salvação aparece sob efeito de ironia, já que a o sacrifício é uma cômica relação homossexual contra os princípios de Eugênio.

Essa figura também é importante na construção de sentido de O Natimorto; de tal maneira que é referida no título do romance. Contudo, a primeira das diferenças em relação às outras aparições é a de que ela não se realiza completamente. O sacrifício que efetivaria um modo de ser ideal (semelhante ao da Voz da Pureza) é representado pela imagem do natimorto, cujo percurso é de nascer e morrer sem que os elementos negativos da vida influam na sua condição existencial - de alguma maneira, o natimorto pode ser considerado uma figura mitológica, na medida em que nascido morto, une os dois termos opostos da categoria semântica vida x morte.

A "natimorte" ocorre apenas em sentido metafórico, nos momentos em que o narrador-personagem se priva de entrar em contato com elementos do mundo natural que possam interferir na sua relação patêmica com a realidade. Um exemplo dela é a resistência deliberada, e sem êxito completo, à atração sexual causada pela Voz. Por isso, quando ele percebe que o Maestro irá conquistá-la, qualifica a si próprio como natimorto; pois assim termina um relacionamento sem que ele tenha iniciado:

"Hoje,

para mim,

o Natimorto. 


\author{
Eu represento \\ o que ele \\ de fato \\ representa \\ Natimorro." (Mutarelli, 2004: 104-105)
}

A palavra mais correta para designar essa atitude forçosamente desinteressada diante do mundo não seria sacrifício, mas sim abstenção. Tal como o isolamento dos monges, o Agente se enclausura para se distanciar dos elementos materiais. Novamente é acionada a interdiscursividade com as filosofias de Nietzsche e Schopenhauer, que dialogam com o budismo. Isso porque, segundo seus pontos de vista, o árduo regime da vida, no qual se intercalam construção e destruição, conseqüentemente, prazer e dor, teria como uma das soluções a suspensão das vontades - tal solução se associa o budismo. Segundo Nietzsche:

\footnotetext{
"Para sair do orgiasmo não há, para um povo, senão um caminho, o caminho do budismo indiano, o qual, para ser suportável em seu anseio do nada, necessita daqueles raros estados extáticos, com sua elevação acima do espaço, do tempo e do indivíduo, assim como estes, por seu turno, exigem uma filosofia que ensine a superar, através de uma representação, o indescritível prazer dos estados intermediários." (Nietzsche, 1998: 124)
}

Portanto, no que diz respeito ao discurso de $O$ Natimorto, é possível depreender que o tema principal consiste na forma de lidar com o indefectível término do que existe. Considerando o dado disfórico de sentir esse processo, aventa-se a possibilidade de tornar constante a paixão da indiferença para impedir a valoração negativa. O narradorpersonagem adere a tal solução, concretizando uma espécie de paródia de vida monge, e por conta dela se constrói em grande parte o ethos do desequilíbrio psicológico.

Paralelamente a essa temática filosófico-existencial, há ainda discussões do âmbito da sociedade, pois a destruição que atinge e é conseqüência dos elementos inanimados também pode ser encontrada na forma das ações humanas, dessa vez, moralizada negativamente como uma postura constante e censurável da maior parte dos homens. Já que a atitude de não-conjunção com os elementos construtivos, ligados à pureza, é delegada à esfera do ideal ou do mito (voz inaudível, natimorto), a ação que realiza o narrador- 
personagem opera a transformação de sua relação fórica com a destruição, e a assunção de uma postura que a exerce. Combinam-se conformismo e vingança em resposta a uma realidade material cuja lógica não permite existência sem fim e a uma sociedade que sustenta infidelidade, violência, jogos de interesse e insensibilidade.

Para se dar a relação do texto com a tradição literária brasileira, ressalta-se que os mesmos temas e transformações estão presentes na poesia de Augusto dos Anjos. Seu famoso poema "Versos Íntimos" é bem ilustrativo no que diz respeito a essas características. De modo análogo ao episódio do cão e à decisão de assassinar a cantora que não cumpre com a espera simples do Agente, o eu lírico do referido poema decide tomar as mesmas atitudes disforizadas no início do texto, em que se apresenta o enterro vazio de sua quimera:

“Acostuma-te à lama que te espera!

O Homem, que, nesta terra miserável, Mora, entre feras, sente inevitável

Necessidade de também ser fera.

Toma um fósforo. Acende teu cigarro! o beijo, amigo, é a véspera do escarro, A mão que afaga é a mesma que apedreja.

Se a alguém causa inda pena a tua chaga, Apedreja essa mão vil que te afaga, Escarra nessa boca que te beija!"

A contraposição dos planos material e ideal também está presente em $O$ Cheiro do Ralo, correspondendo o primeiro à totalidade disforizada, e o segundo, à parcialidade euforizada. Para a efetivação do ideal, no texto cujo personagem principal é o dono da loja de penhores, o romance, a despeito de sua negação pelo discurso do narrador, se realiza, e apenas mediante a morte desse último por conta de sua completa conjunção com o objeto de valor disforizado. Em O Natimorto, o processo se inverte. O assassinato da Voz, 
sugerido nos últimos parágrafos, configura a total realização, no enunciado, da conjunção com o objeto de valor disforizado. Se no primeiro caso, há um encerramento "feliz" e idealista; no segundo, o pessimismo calcado no âmbito material cumpre o papel de desenlace do texto. 


\section{CONCLUSÃO}

As características que unem $O$ Cheiro do Ralo e Jesus Kid, de forma a distanciá-los de $O$ Natimorto, dizem respeito, sobretudo, à enunciação, ao modo de construir o ethos do desequilibrado e à metalinguagem. Todos esse elementos, na verdade, podem ser entendidos como um só aspecto, pois a reunião dos três em cada texto contribui para um mesmo sentido em ambos os casos, a despeito de a relação entre esse aspecto e a totalidade de significado ser diferente em cada romance.

O desequilíbrio psicológico do dono da loja de penhores e do roteirista, tomado em sua função maior, decorre da idéia fixa de escrever, da necessidade de elaborar um romance ou um roteiro, por conta de problemas financeiros ou desinteresse diante de um mundo cujos elementos se tornam iguais na medida em que adquirem o caráter de mercadoria. Esse desequilíbrio fundamenta a presença de clichês, os jogos enunciativos, o uso de paródias e os problemas de veredicção pelo narrador Eugênio.

A metalinguagem surge nesses dois casos para indicar o lugar da literatura diante dessas realidades. Segundo a indicação, seu papel é negar a condição de totalidade dos elementos do mundo natural, por isso, em $O$ Cheiro do ralo, ela aparece como salvação efeito do uso do lítotes. Como o conteúdo de Jesus Kid é mais diretamente voltado para a crítica ao mercado editorial e à recepção da literatura, mais apreciada na forma de roteiro, o caráter salvador surge apenas ironicamente. De modo menos idealista do que no primeiro romance, a literatura de boa qualidade deve negar de alguma maneira as coerções textuais impostas por editores, produtores de cinema e o público. No romance anterior já há dados pontuais que revelam o mesmo ponto de vista:

"O consultório é cheio de livros.

Mas esses livros não são como os meus.

Esses livros não tem histórias.

As gráficas não deviam fazer esse tipo de livro.

Esses livros não deveriam ser lidos.

Esses livros nos tiram a história.

Esses livros não deixam ser eu.

Esses livros só trazem receitas. ” (Mutarelli, 2002: 72) 
Nesse caso, a paródia é um recurso providencial, porque, com ela, é possível utilizar os elementos exigidos, criticando quem os assume como válidos.

A literatura não pode ser considerada tema central de O Natimorto. Como está visto, o percurso temático envolve discussões existenciais e morais que estabelecem intertextualidade com a filosofia alemã do final do século XIX. Assim, a literatura, que é tema do centro dos outros romances, torna-se elemento marginal; enquanto que aspectos como reflexões sobre identidade individual, sociedade hostil e fugacidade da existência, passam de marginais a dados do centro da configuração discursiva.

Um processo semelhante ocorre no que tange ao desequilíbrio psicológico, ethos de efeito de sentido crucial na obra de Lourenço Mutarelli. Se nos romances metalingüísticos sua função é primordialmente indicar o querer ou dever entrar em conjunção com o âmbito literário cuja proposta não é conivente com a realidade que vige; em O Natimorto, ele parece decorrer da simples associação isotopias, em busca de um sentido global que os organize (geralmente, o tarô construído a partir das advertências de cigarro); do mesmo modo que o narrador-personagem busca decifrar padrões no tapete do quarto do hotel. Conseqüência de tal procedimento é a forma estritamente interpretativa não convincente, particular a esse texto em relação aos outros.

Esse modo de operar assemelha-se ao que Lévi-Strauss define como pensamento mágico em oposição ao científico:

\footnotetext{
"Os cientistas suportam a dúvida e o fracasso, porque não podem fazer de outra maneira. Mas a desordem é a única coisa que não podem nem devem tolerar. " (Lévi-Strauss, 1989: 24)
}

"Desse ponto de vista, a primeira diferença entre magia e ciência seria, portanto, que uma postula um determinismo global e integral enquanto a outra opera distinguindo níveis dos quais apenas alguns admitem formas de determinismo tidas como inaplicáveis a outros níveis." (Lévi-Strauss, 1989: 26)

Tendo como base os excertos acima, é possível afirmar que a interpretação que rege a percepção do narrador de $O$ Natimorto utiliza princípios antes de contextos antigos do que efetivamente equivocados. Tanto a defesa da boa literatura quanto a construção de um 
personagem que regride ao pensamento mágico podem ser consideradas modos de figurativizar a relação disfórica do enunciador com o que se depreende ser uma padronização dos meios perceptivos de se lidar com o mundo.

Portanto, o encantamento e a mitologia, que são elementos menos centrais nos outros romances, aparecem, nesse caso, no cerne do tema, que, em se pensando no discurso geral do enunciador Lourenço Mutarelli, são figuras, assim como a literatura e o jogo (relembrase que tarô também é um jogo), que concretizam a defesa do uso autônomo da percepção, e o recurso livre ao imaginário.

Tem-se, dessa maneira, a categoria totalidade $\mathrm{x}$ parcialidade, organizando a obra romanesca estudada neste trabalho, de modo que a primeira é disforizada, e a segunda, euforizada. Ressalta-se, porém, que o discurso em questão não consiste numa crítica ao pensamento científico em sua essência, mas no seu uso: a predominância em todos os âmbitos do pensamento, podendo causar distúrbios psicológicos, por conta da necessidade humana de imaginar. 


\section{BIBLIOGRAFIA}

ANJOS, Augusto dos (1996). Obra Completa. Rio de Janeiro, Nova Aguilar. ASSIS, Machado de (2006). Obra Completa. Rio de Janeiro, Nova Aguilar.

ARISTÓTELES (1998). Poética. Imprensa Nacional - Casa da Moeda.

BARROS,D.L.P. de (1988). Teoria do discurso: fundamentos semióticos. São Paulo, Atual. (1990). Teoria semiótica do texto. São Paulo, Ática.

BERTRAND, Denis (2003). Caminhos da semiótica literária. São Paulo, EDUSC.

FIORIN, J. L. (1988). Linguagem e ideologia. São Paulo, Ática. (1989). Elementos de análise do discurso. São Paulo, Contexto/EDUSP. (1996). As astúcias da enunciação. São Paulo, Ática.

FONTANILLE, J. \& ZILBERBERG, C. (1998). Tensão e significação. São Paulo, Humanitas.

GREIMAS, A. s.d.. Semântica estrutural. São Paulo, Ática. s. d.*. Semiótica e ciências sociais. São Paulo, Cultrix \& COURTÉS, J. s.d.. Dicionário de semiótica. São Paulo, Ática. e outros (1975). Ensaios de semiótoca poética. São Paulo, Cultrix/EDUSP. (1976). Semiótica do discurso científico/Da modalidade. DIFEL/SBPL. e outros (1977). Semiótica narrativa e textual. São Paulo, Cultrix/EDUSP. \& LANDOWSKI, E. (1986). Análise do discurso em ciências sociais. São Paulo, Global.

(1997). De la imperfección. México, Fondo de Cultura Económica. \& FONTANILLE, J. (1993). Semiótica das paixões. São Paulo, Ática.

HJELMSLEV, L. (1975). Prolegômenos a uma teoria da linguagem. São Paulo, Perspectiva.

(1991). Ensaios lingüísticos. São Paulo, Perspectiva.

JAKOBSON, R. (2003.) Lingüística e comunicação. São Paulo, Cultrix.

KAFKA, Franz (1997). A Metamorfose. São Paulo, Cia das Letras. (1997). O Processo. São Paulo, Cia das Letras.

KANT. Immanuel (2007). Crítica da Faculdade do Juízo. Rio de Janeiro, Forense Universitária.

LANDOWSKI, E. (1992). A sociedade refletida. São Paulo, Pontes/EDUC. 
LÉVI-STRAUSS, Claude (1989). O pensamento selvagem. Campinas, São Paulo: Papirus.

MAINGUENEAU Dominique (2005). Gênese dos discursos. Curitiba, Criar. (2001). O contexto da obra literária. São Paulo, Martins

Fontes.

MUTARELLI, Lourenço (2002). O Cheiro do Ralo. São Paulo, Devir. (2004). O Natimorto - um musical silencioso. São Paulo, DBA. (2004) Jesus Kid. São Paulo, Devir.

NASSAR, Raduan (2003). Lavoura Arcaica. São Paulo, Cia das Letras. (2002). Menina a caminho. São Paulo, Cia das Letras. (2006). Um copo de cólera. São Paulo, Cia das Letras.

NIETZSCHE, Friedrich Wilhelm (1998). O nascimento da tragédia. São Paulo, Cia das Letras. (2000). Além do bem e do mal. São Paulo, Cia das Letras.

POMPEIA, Raul (1990). O Ateneu. São Paulo, Moderna.

SAPIR, E. (1969). Lingüística como ciência. Rio de Janeiro, Acadêmica.

SAUSSURE, F. de s. d.. Curso de lingüística geral. São Paulo, Cultrix.

SCHNAIDERMAN, B. (1979). Semiótica russa. São Paulo, Perspectiva.

SCHOPENHAUER, Arthur (1966). O mundo como vontade e representação. Rio de Janeiro, Edições de Ouro.

SILVA, I. A. (1995). Figurativização e metamorfose. São Paulo, UNESP. e outros (1996). Corpo e sentido. São Paulo, UNESP.

TATIT, L. (1986). A canção. São Paulo, Atual. (1994). Semiótica da canção. São Paulo, Escuta. (1996). O cancionista. São Paulo, EDUSP. 